JUSSARA GONÇALVES FERNANDES

\title{
ANÁLISE COMPARATIVA DOS PROCESSOS INFLAMATÓRIOS AGUDO E CRÔNICO NO TECIDO SUBCUTÂNEO E EXSUDATO EM CAMUNDONGOS SELECIONADOS PARA MÁXIMA OU MÍNIMA INFLAMAÇÃO
}

Dissertação apresentada ao Programa de Pós-Graduação em Imunologia do Instituto de Ciências Biomédicas da Universidade de São Paulo, para obtenção do Título de Mestre em Ciências. 
JUSSARA GONÇALVES FERNANDES

\section{ANÁLISE COMPARATIVA DOS PROCESSOS INFLAMATÓRIOS AGUDO E CRÔNICO NO TECIDO SUBCUTÂNEO E EXSUDATO EM CAMUNDONGOS SELECIONADOS PARA MÁXIMA OU MÍNIMA INFLAMAÇÃO}

Dissertação apresentada ao Programa de Pós-Graduação em Imunologia do Instituto de Ciências Biomédicas da Universidade de São Paulo, para obtenção do Título de Mestre em Ciências.

Área de concentração: Imunologia

Orientador: Prof. Dr. Marcelo de Franco

Versão original 
DADOS DE CATALOGAÇÃO NA PUBLICAÇÃO (CIP)

Serviço de Biblioteca e Informação Biomédica do

Instituto de Ciências Biomédicas da Universidade de São Paulo

reprodução não autorizada pelo autor

Fernandes, Jussara Gonçalves.

Análise comparativa do processo inflamatório agudo e crônico no tecido subcutâneo e exsudato em camundongos selecionados para máxima ou mínima inflamação / Jussara Gonçalves Fernandes. -- São Paulo, 2012.

Orientador: Prof. Dr. Marcelo de Franco.

Dissertação (Mestrado) - Universidade de São Paulo. Instituto de Ciências Biomédicas. Departamento de Imunologia. Área de concentração: Imunologia. Linha de pesquisa: Pesquisa dos genes reguladores da reação inflamatória aguda.

Versão do título para o inglês: Comparative analysis of acute and chronic inflamatory processes of the subcutaneos tissue and exudate in mice genetically selected for maximal or minimal inflammation.

1. Inflamação 2. Camundongos 3. Expressão Gênica 4. Citocinas 5. Fenótipo 6. Genes I. Franco, Prof. Dr. Marcelo de II. Universidade de São Paulo. Instituto de Ciências Biomédicas. Programa de PósGraduação em Imunologia III. Título. 
Candidato(a): $\quad$ Jussara Gonçalves Fernandes.

Título da Dissertação: $\quad$ Análise comparativa do processo inflamatório agudo e crônico no tecido subcutâneo e exsudato em camundongos selecionados para máxima ou mínima inflamação.

Orientador(a): $\quad$ Prof. Dr. Marcelo de Franco.

A Comissão Julgadora dos trabalhos de Defesa da Dissertação de Mestrado, em sessão pública realizada a ........ ...................,

\section{( ) Aprovado(a) ( ) Reprovado(a)}
Examinador(a): Assinatura: Nome:
Instituição:

Examinador(a): Assinatura:

Nome:

Instituição:

Presidente: Assinatura:

Nome:

Instituição: 


\section{UNIVERSIDADE DE SÃO PAULO INSTITUTO DE CIÊNCIAS BIOMÉDICAS}

Cidade Universitária "Armando de Salles Oliveira"

Av. Prof. Lineu Prestes, 2415 - CEP. 05508-000 São Paulo, SP - Brasil

Telefone :(55) (011) 3091.7733 - e-mail: cep@icb.usp.br

\section{Certificado}

Certificamos que o protocolo registrado sob $n^{\circ} \mathbf{4 2}$ nas fls. 86 do livro 02 para uso de animais em experimentação, sob a responsabilidade do Prof(a) $\operatorname{Dr}(a)$ Marcelo De Franco, Coordenador(a) da Linha de pesquisa Análise comparativa dos processos inflamatórios agudos e crônicos do tecido subcutâneo e exsudato em camundongos geneticamente selecionados para máximo ou minima inflamação do qual participou(aram) o(s) Jussara Gonçalves Fernandes,Tatiane Aparecida Canhamero Gasparelo,Mariana Perlati dos Santos, Mara Adriana Correa e os pesquisadores Olga Célia Martinez Ibañez,Orlando Garcia Ribeiro Filho, Nancy Starobinas, Wafa Hanna Koury Cabrera, José Ricardo Jensen, está de acordo com os Princípios Éticos de Experimentação Animal adotado pela Sociedade Brasileira de Ciência de Animais de Laboratório (SBCAL) e foi aprovado pela COMISSÃO DE ÉTICÄ NO USO DE ANIMAIS (CEUA) em 20.04.2010, com validade de 3 anos.

São Paulo, 20 de abril de 2010.

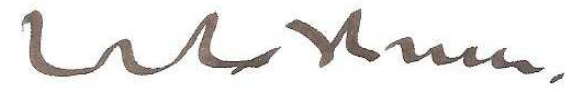

Prof.Dr.WOTHAN TAVARES DE LimA Coordenador CEEA - ICB/USP

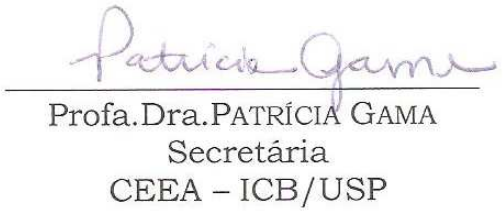

CEEA - ICB/USP 
A Deus

Aos meus pais Jucemara (Mara) e Luíz (Zinho), que estiveram sempre ao meu lado, me ajudando, me apoiando e orando muito por mim. Obrigada pelo incentivo, pelo amor, carinho e compreensão.

Agradeço por poder sempre contar com vocês. 


\section{AGRADECIMENTOS}

Ao meu orientador Marcelo de Franco, que me aceitou como aluna, possibilitando a iniciação do meu mestrado e contribuindo para o meu crescimento pessoal e científico. Meus agradecimentos sinceros pela paciência, compreensão, carinho e ajuda.

À Dra. Olga Célia pelo aprendizado, sugestões e contribuição científica.

Aos pesquisadores do laboratório de Imunogenética, Dra. Wafa Cabrera, Dr. Orlando Garcia, Dra. Nancy Starobinas, Dra. Andrea Borrego, Dra. Mônica Spadafora, Dr. José Ricardo Jensen, Dra. Milene de Franco, Dra. Solange Carbonare e Dra. Solange Massa, pelo carinho e disposição em ajudar quando foi preciso.

À amiga Tati, minha vizinha de mesa, pela amizade, conversas, cantorias e por toda ajuda imprescindível nos experimentos, e sempre que foi necessário.

Aos amigos que fiz durante o período no laboratório, lana Katz, Layra Albuquerque, Cristiano Rossato, Alessandra Suppa, Priscillia Aguilar, Camila, Mariana Perlati, Mara Correa, Aline Lavezo, Lilian Rego, Priscila Lara, Thais Rodrigues, Fernanda Ampessan e Renata Nunes, agradeço de coração pela amizade e por tornarem os dias de trabalho no laboratório e fora dele sempre agradáveis.

Aos funcionários do laboratório Andressa Rogge, pela amizade, Sandra Ottoboni, Mara Irineu, Tânia Vieira, Neusa Miranda e Ronaldo, pela boa convivência e preparação dos materiais utilizados.

Aos funcionários do Biotério, Marinalva Lima, Marinalva Santos, Aline, Celso, Joel e Rosa Maria, pela manutenção e cuidado com os animais que foram utilizados nos experimentos. 
Ao meu companheiro e namorado Jefferson, obrigada por ter estado ao meu lado durante todo o período do mestrado, por aguentar meu nervosismo, minhas frustações e meu mau humor em alguns momentos. Obrigada por me incentivar, me apoiar e me dizer as palavras certas na hora certa. Sua companhia, seu amor, carinho e ajuda, foram de valores inestimáveis.

À minha irmã Carolina, ao meu cunhado Wagner e ao meu afilhado Leo, obrigada por todos os momentos bons, e por fazerem parte dessa família linda que temos.

Aos meus familiares e a todos os amigos e amigas que de alguma forma contribuíram com o desenvolvimento deste trabalho. Obrigada pelos momentos de distração, alegria e boas conversas. 
"Há pessoas que desejam saber só por saber, e isso é curiosidade; outras, para alcançarem fama, e isso é vaidade; outras, para enriquecerem com a sua ciência, e isso é um negócio torpe; outras, para serem edificadas, e isso é prudência; outras, para edificarem os outros, e isso é caridade." 


\section{RESUMO}

FERNANDES, J. G. Análise comparativa dos processos inflamatórios agudo e crônico no tecido subcutâneo e exsudato em camundongos selecionados para máxima ou mínima inflamação. 2012. 87 f. Dissertação (Mestrado em Imunologia) - Instituto de Ciências Biomédicas, Universidade de São Paulo, São Paulo, 2012.

Linhagens de camundongos AIRmax e AIRmin diferem quanto a reatividade inflamatória aguda às partículas de Biogel. Essas linhagens foram desenvolvidas com o intuito de identificar os genes que afetam a intensidade da resposta inflamatória aguda (AIR) e compreender os mecanismos celulares e moleculares da inflamação. A AIR divergente nessas linhagens está bem estabelecida, no entanto, diferenças na resposta inflamatória tardia ou crônica ao Biogel ainda não foram descritas. Dessa forma, no presente trabalho nós decidimos avaliar se o processo de seleção que modificou a resposta inflamatória aguda nessas linhagens, também afetou o desenvolvimento da resposta inflamatória crônica. Foi verificado que a infiltração de células no exsudado da linhagem AIRmax foi significativamente maior que na linhagem AIRmin em ambos os períodos avaliados (48 h e 30 dias), e que no período de 48 horas, os camundongos AIRmax também apresentaram alta produção de algumas citocinas no exsudato inflamatório. O perfil de expressão gênica global do tecido subcutâneo mostrou maior número de genes ativados nos AIRmax envolvidos na transdução de sinal, resposta imune e inflamatória do que em camundongos AIRmin. Além disso, esses dados mostraram que alguns desses genes diferentemente expressos, estão localizados na região do locus Irm1, um QTL previamente mapeado que mostrou estar envolvido com a regulação da intensidade da AIR. Alguns genes envolvidos com a resposta inflamatória aguda, também apresentaram diferenças após 30 dias. Os nossos resultados indicam que o processo de seleção para a resposta inflamatória aguda pode ter afetado também o desenvolvimento da resposta inflamatória crônica ao agente selecionador das linhagens. Dessa forma o presente trabalho contribui na identificação de fatores genéticos que controlam tanto a intensidade da resposta inflamatória aguda como a intensidade da resposta inflamatória crônica.

Palavras-chave: Inflamação. Camundongos. Expressão gênica. Citocinas. Fenótipo. Genes. 


\begin{abstract}
FERNANDES, J. G. Comparative analysis of acute and chronic inflammatory processes of the subcutaneous tissue and exudate in mice genetically selected for maximal or minimal inflammation. 2012. 87 p. Masters thesis (Immunology) Instituto de Ciências Biomédicas, Universidade de São Paulo, São Paulo, 2012.

AIRmax and AIRmin mouse lines differ in terms of acute inflammatory response after Biogel injection. These lines were developed in order to identify genes that affect the acute inflammatory response intensity (AIR) and to understand their cellular and molecular roles. The distinct AIR in these lines is well established, however, differences in late or chronic inflammatory response to Biogel were not described yet. Thus, in the present work we decided to check if the genetic selection that modified the acute inflammatory response in these lines, also affected the development of a chronic inflammatory response to Biogel. We found that AIRmax mice had statistically higher cellular influx in the inflammatory exudate than AIRmin mice in both analyzed periods (48 $\mathrm{h}$ and 30 days) and that after 48 hours of Biogel injection, AIRmax mice showed higher cytokine levels in inflammatory exudate, probably contributing to the cellular influx profile in these lines. The global gene expression analysis in sc tissue showed higher number of up-regulated genes in AIRmax than in AIRmin mice involved with inflammatory response, immune response and signal transduction. Furthermore, these results showed that some of the differentially expressed genes are located in Irm1 locus region, a previously mapped QTL shown to be involved in AIR regulation. Some acute inflammatory response genes, besides being differentially expressed between the lines 48 hours after stimulus, also showed differences on day 30 . Our results indicate that the genetic selection for acute inflammatory response may also have affected the chronic inflammatory response to Biogel. In this way, this work contributes to identify genetic factors controlling not only the acute inflammatory response intensity, but the chronic inflammatory response as well.
\end{abstract}

Key words: Inflammation. Mice. Gene expression. Cytokines. Phenotype. Genes. 


\section{LISTA DE ABREVIATURAS E SIGLAS}

AIR - Resposta Inflamatória Aguda

CCL2 - Quimiocina Ligante 2 (Motivo C-C)

Ct - Cycle Threshold

CXCL1 - Quimiocina Ligante 1 (Motivo C-X-C)

CXCL2 - Quimiocina Ligante 2 (Motivo C-X-C)

CXCR2 - Receptor de Quimiocina 2

DAMP - Padrão Molecular Associado ao Dano

DMBA - 7,12-Dimetilbenzantraceno

EASE - "Expression Analysis Systematic Explorer"

ECM - Matriz Extracelular

FDR - "False Discovery Rate"

GM-CSF - Fator Estimulador de Colônia Granulócito-Macrófago

ICAM - Molécula de Adesão Intercelular 1

IL-1 $\beta$ - Interleucina 1 Beta

IL-6 - Interleucina 6

IL-10 - Interleucina 10

IL-17 - Interleucina 17

ITGB2 - Integrina Beta 2

LFA-1 - Antígeno Associado à Função de Linfócito 1

LPS - Lipopolissacarídeo

MAC-1 - Antígeno 1 de macrófago

MMP - Metaloproteinase

mRNA - RNA mensageiro

NFkB - Fator Nuclear KappaB

NLRP3 - Receptor do tipo NOD contendo domínio Pirina 3

NLR - Receptores do tipo NOD

PAMP - Padrões Moleculares Associados a Patógenos

PCR - Reação em Cadeia da Polimerase

PECAM-1 - Molécula de Adesão Celular Endotelial/Plaquetária 1

PRR - Receptores de Reconhecimento Padrão

QTL - "Quantitative Trait Loci"

SAM - "Significance Analysis of Microarray"

SNP - "Single Nucleotide Polymorfism"

TGF- $\beta$ - Fator Transformador do Crescimento Beta

TNF- $\alpha$ - Fator de Necrose Tumoral Alfa 
TNFR - Receptor do Fator de Necrose Tumoral

TPA - 12-O-tetradecanoil-forbol-13-acetato

VCAM - Molécula de Adesão Celular Vascular

VLA-4 - Integrina 4 Alfa 


\section{LISTA DE ILUSTRAÇÕES}

Figura 1 - Divergência entre as linhagens AIR quanto à resposta inflamatória....................26

Figura 2 - Quantificação da expressão do gene ciclofilina..............................................39

Figura 3 - Número de células extravasadas ao sítio de aplicação Biogel nos animais

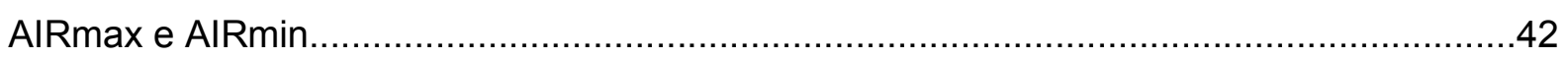

Figura 4 - Níveis das citocinas IL-1 $\beta$, TNF- $\alpha$, IL-6 e CCL2 no exsudato..............................44

Figura 5 - Níveis de IL-17 e IL-10 no soro..............................................................45

Figura 6 - Níveis de IL-6, CXCL2 e TGF- $\beta$ no soro...........................................................46

Figura 7 - Genes ativados no tecido das linhagens AIRmax e AIRmin...............................49

Figura 8 - Genes ativados no tecido das linhagens AIRmax e AIRmin.................................51

Figura 9 - Genes ativados no tecido de camundongos AIRmax......................................45

Figura 10 - Genes reprimidos no tecido de camundongos AIRmax ..................................53

Figura 11 - Genes mais expressos na linhagem AIRmax em relação a linhagem AIRmin...54

Figura 12 - Genes mais expressos na linhagem AIRmax em relação a linhagem AIRmin...56

Figura 13 - Genes mais expressos na linhagem AIRmin em relação a linhagem AIRmax...57

Figura 14 - Genes mais expressos na linhagem AIRmax em relação a linhagem AIRmin...57

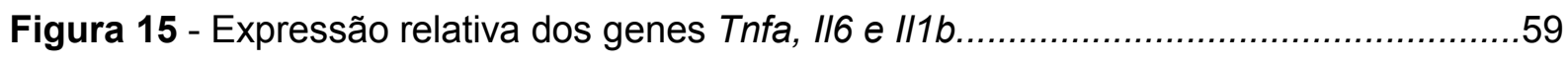

Figura 16 - Expressão relativa dos genes $C x c / 1, C x c / 2$ e Cxcr2 .....................................60

Figura 17 - Expressão relativa dos genes Cc/2 e Itgb2 ....................................................61

Figura 18 - Expressão relativa dos genes Tgfb e Vcam1 ............................................62

Figura 19 - Expressão relativa do gene Mmp9............................................................63

Figura 20 - Macroscopia do tecido subcutâneo dos camundongos AIRmax e AIRmin.........65

Figura 21 - Cortes histológicos do tecido subcutâneo de animais AIRmax e AIRmin..........65 


\section{LISTA DE TABELAS}

Tabela 1 - Migração de células ao exsudato inflamatório dos animais AIRmax e AIRmin....43

Tabela 2 - Número de genes ativados e reprimidos nas linhagens AIR. 47

Tabela 3 - Número de genes diferentemente expressos entre animais AIRmax e AIRmin controles. .48

Tabela 4 - Número de genes diferentemente expressos entre animais AIRmax e AIRmin após 48 horas da aplicação de Biogel. .41 


\section{SUMÁRIO}

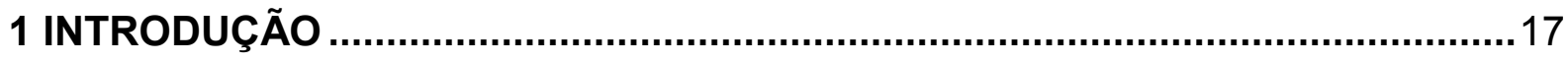

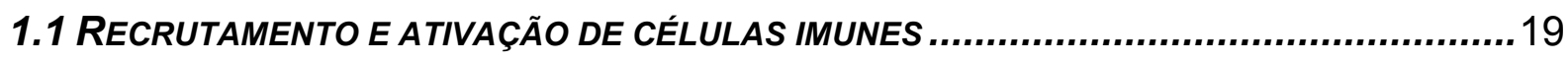

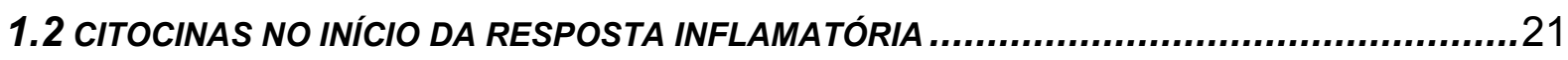

1.3 RESOLUÇÃO OU CRONIFICAÇÃO DA RESPOSTA INFLAMATÓRIA .................................23

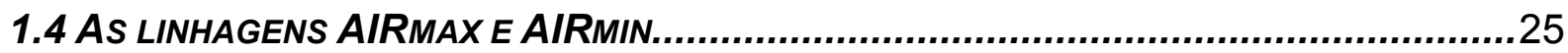

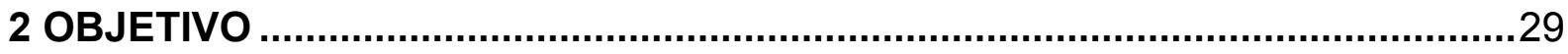

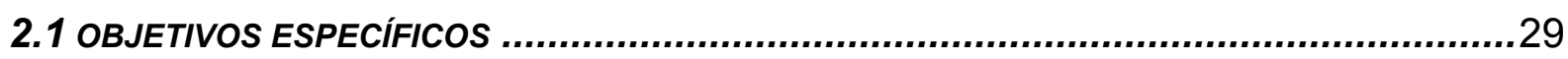

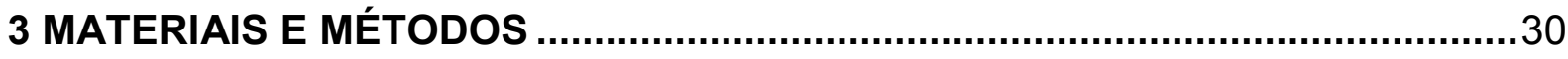

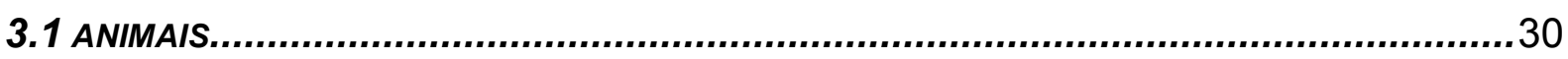

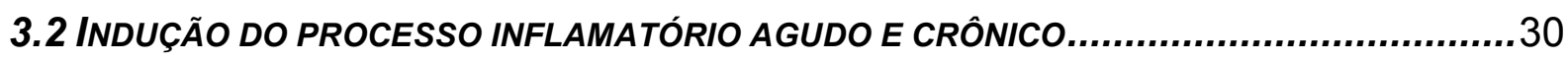

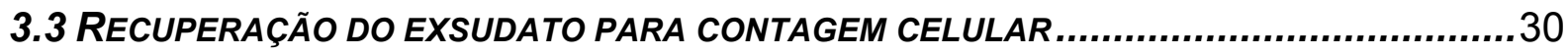

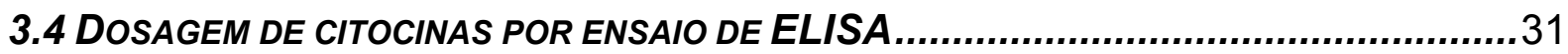

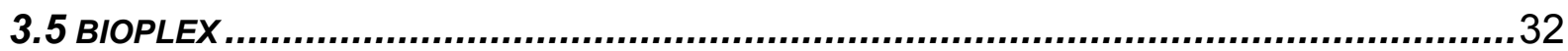

3.6 EXTRAÇÃO DE RNA TOTAL DO TECIDO SUBCUTÂNEO DOS CAMUNDONGOS..................33

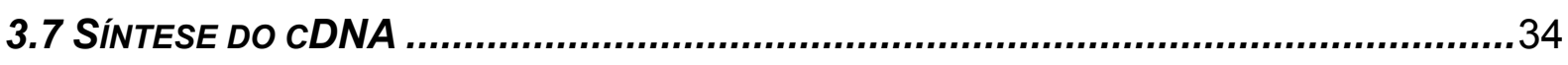

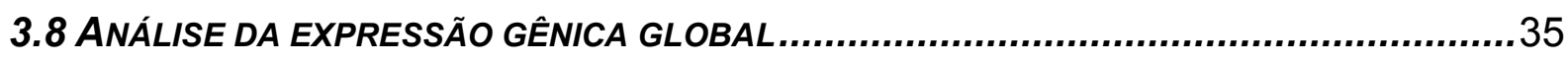

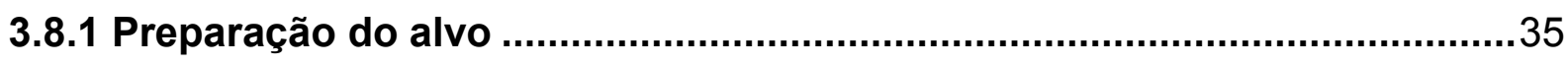

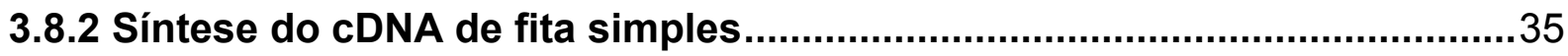

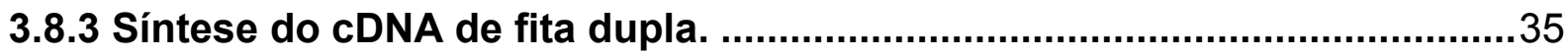

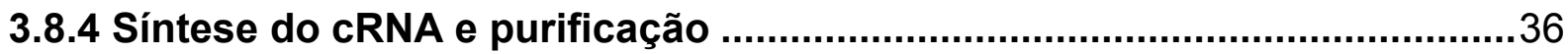

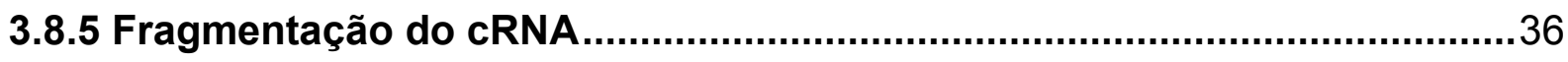

3.8.6 Hibridação e Detecção com streptavidina ..............................................36

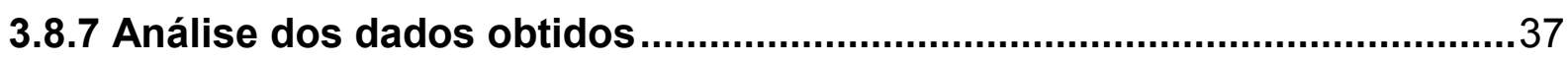

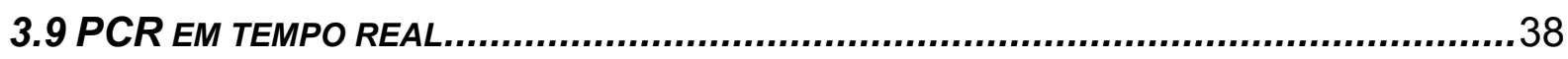

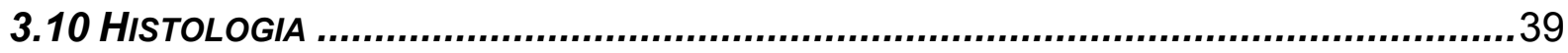

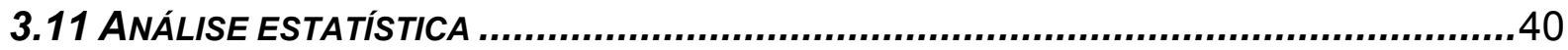

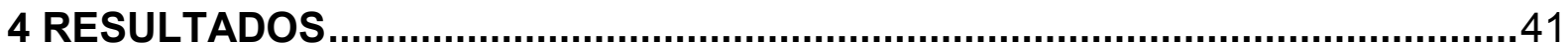

4.1 INFILTRAÇÃO DE CÉLULAS NO EXSUDATO PRODUZIDO PELO BIOGEL ..........................41

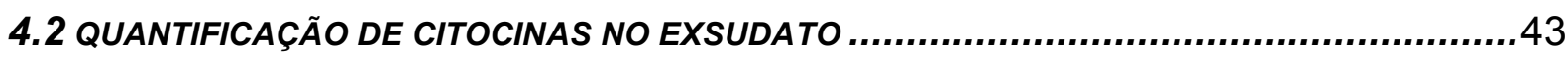

4.3 DETECÇÃo DE CITOCINAS INFLAMATÓRIAS NO SORO............................................44

4.3.1 Níveis de IL-17 e IL-10 no soro..............................................................45

4.3.2 Níveis de outras citocinas no soro ........................................................45 


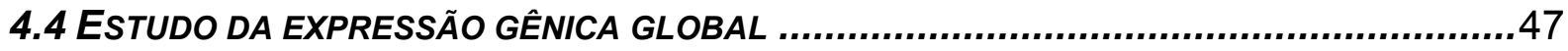

4.5 ANÁLISE DA EXPRESSÃO GÊNICA POR PCR EM TEMPO REAL ..................................58

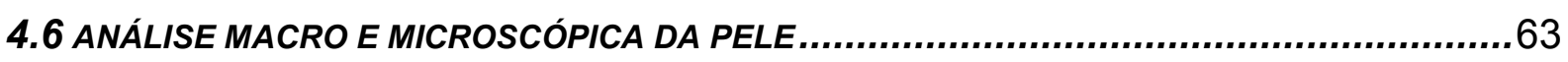

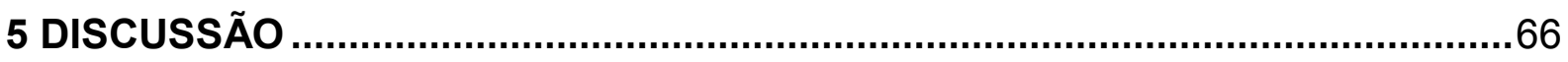

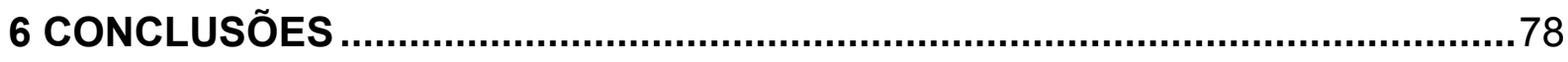

REFERÊNCIAS ....................................................................................... 80 


\section{INTRODUÇÃO}

A resposta inflamatória tem um papel importante na defesa do organismo e é a primeira linha de defesa que protege o hospedeiro contra a contaminação microbiana e lesão tecidual visando restaurar a homeostasia e integridade do tecido. Apesar de a resposta inflamatória ser essencial e inicialmente benéfica para o hospedeiro, uma resposta desenvolvida inadequadamente, pode muitas vezes ser prejudicial (MEDZHITOV, 2008; PERRETI, 1997).

Os sinais clássicos da resposta inflamatória são descritos como rubor, calor, edema, dor e perda de função. Esses sinais são decorrentes de alterações nos vasos sanguíneos como a contração da musculatura lisa endotelial, vasodilatação e aumento da permeabilidade vascular levando a um consequente extravasamento de fluído rico em proteínas para o tecido, seguido de infiltração celular (NATHAN, 2002; RYAN; MAJNO, 1977; SERHAN, 2004).

Um dos maiores estimuladores da inflamação é a infecção, que pode ser causada por uma série de microrganismos patogênicos como vírus, bactérias e fungos. Além disso, a inflamação também pode ser desencadeada por uma variedade de estímulos estéreis ou não infecciosos, como produtos químicos, toxinas, isquemia e reperfusão, trauma, corpos estranhos, entre outros, sendo que estes podem ser classificados como agentes irritantes, injuriosos ou antigênicos (CHEN; NUÑEZ, 2010; ROCK et al., 2010).

Assim como a inflamação induzida por agentes microbianos, a inflamação estéril é caracterizada principalmente pela infiltração de neutrófilos e macrófagos e produção de quimiocinas e citocinas tais como TNF- $\alpha$, IL-1 $\beta$ e IL-6 (CHEN; NUÑEZ, 2010). Apesar de as respostas inflamatórias infecciosas e não infecciosas serem muito semelhantes e levarem às mesmas manifestações vasculares e celulares, os eventos iniciais podem ser muito diferentes (MEDZHITOV, 2010; ROCK et al., 2010).

Os receptores de reconhecimento padrão (PRRs) como os receptores semelhantes a Toll e receptores do tipo NOD (NLR) são descritos por participarem da defesa imune inata contra agentes microbianos, reconhecendo estruturas comuns e invariáveis entre patógenos, como ácidos nucléicos e lipídios, chamados de padrões moleculares associados a patógenos (PAMPs) (MARTINON; MAYOR; TSCHOPP, 2009; MEDZHITOV; JANEWAY, 2000). Embora esses receptores sejam 
descritos por reconhecerem principalmente um estímulo exógeno microbiano, estudos têm demonstrado que os PRRs também podem reconhecer componentes da inflamação estéril liberados durante uma injúria tecidual. Esses componentes são chamados de DAMPs (padrões moleculares associados ao dano) e eles têm função similar aos PAMPs em termos de ativação da sinalização pró-inflamatória (CHEN; NUÑEZ, 2010; JIANG et al., 2005).

DAMPs são normalmente fatores endógenos que são mantidos dentro das células, portanto protegidos do reconhecimento de receptores de células imunes em condições normais. Em condições de injúria tecidual, essas moléculas são liberadas no espaço extravascular por células mortas e, portanto podem ser reconhecidas por tais receptores (CHEN; NUÑEZ, 2010). Algumas moléculas endógenas liberadas de células necróticas têm sido descritas por se ligarem a receptores semelhantes a Toll como proteínas HSPs, HMBG1, ácido úrico e nucleotídeos endógenos, assim como componentes da matriz extracelular como o ácido hialurônico, sulfato de heparan e proteoglicanos. Assim, a morte celular necrótica também é um mecanismo que pode desencadear uma inflamação estéril (CHEN; NUÑEZ, 2010; JIANG et al., 2005).

A presença de partículas estranhas dentro do tecido, que não podem ser eliminadas nem fagocitadas por macrófagos, por serem muitas vezes grandes ou resistentes à remoção, também podem iniciar uma resposta inflamatória não infecciosa, que é comumente designada como resposta a um corpo estranho. $\mathrm{O}$ grau de extensão dessa resposta vai depender das propriedades da substância em questão como composição, duração de contato, índice de degradação, morfologia, porosidade, forma, entre outros (MEDZHITOV, 2008; MORAIS; PAPADIMITRAKOPOULOS; BURGESS, 2010).

A persistência dessas partículas como, por exemplo, no caso da implantação de biomateriais ou a penetração de partículas estranhas no organismo por diferentes vias como injeções ou feridas, pode estimular constantemente a inflamação e a difícil remoção e eliminação desses agentes pelas células imunes, pode então levar a uma inflamação crônica, com consequente formação de granulomas (MORAIS; PAPADIMITRAKOPOULOS; BURGESS, 2010). Caso essas substâncias sejam muito grandes para sofrerem fagocitose pelos macrófagos, estes se unem para formar células gigantes e multinucleadas na tentativa de encapsular e "imobilizar" o agente causador do dano (MEDZHITOV, 2008). Um exemplo disso pôde ser 
observado no trabalho de Higgins et al. (2009), onde a implantação subcutânea de uma tira de náilon estéril induziu uma forte resposta a corpo estranho com a presença de células gigantes multinucleadas de origem macrofágica, ao redor do implante.

\subsection{RECRUTAMENTO E ATIVAÇÃO DE CÉLULAS IMUNES}

Os primeiros passos no recrutamento de neutrófilos para o sítio de injúria de inflamação estéril são: a detecção de sinais de perigo (DAMPs), produção de mediadores inflamatórios e a adesão de neutrófilos aos vasos sanguíneos (MCDONALD; KUBES, 2011). Células sentinelas, como macrófagos residentes do tecido e mastócitos têm sido descritos como células importantes para detecção de sinais de perigo, produção de uma variedade de mediadores inflamatórios como citocinas, aminas vasoativas e eicosanoides, e recrutamento de neutrófilos para o sítio de injúria em vários modelos de inflamação estéril (MCDONALD; KUBES, 2011; MEDZHITOV, 2008). O próprio endotélio é capaz de agir como célula sentinela e expressar alguns receptores de várias classes de DAMPs que são capazes de iniciar uma resposta neutrofílica. A ativação de células sentinelas do tecido leva também à produção de grandes quantidades de quimiocinas. As quimiocinas são secretadas principalmente em resposta a estímulos pró-inflamatórios, e sua principal função é regular o tráfico celular, como o de monócitos, neutrófilos e linfócitos (DESHMANE et al., 2009). Duas importantes quimiocinas que participam das respostas inflamatórias agudas neutrofílicas são as quimiocinas CXCL1 (KC) e CXCL2 (MIP-2) (MCDONALD; KUBES, 2011). CXCL2 e CXCL1 são quimiocinas da família CXC que são conhecidas por exercerem suas ações quimiotáticas principalmente em neutrófilos. Ambas se ligam ao receptor murino CXCR2 que é altamente expresso em granulócitos. A expressão de seus mRNAs pode ser detectada em resposta a estímulos microbianos, LPS e a algumas citocinas como IL-1 $\beta$ e TNF- $\alpha$. Podem ser produzidas por macrófagos, e outros tipos celulares, mas os neutrófilos têm sido demonstrados como o maior produtor de CXCL2. Essas células mostraram-se capazes de aumentar a expressão desta quimiocina em resposta a mediadores inflamatórios (ARMSTRONG et al., 2004; MATZER et al., 2001; ROCHE et al., 2007). 
Para alcançar o espaço extravascular em direção ao tecido lesado, os leucócitos passam por processos sequenciais e seletivos dependentes da expressão de moléculas de adesão tais como selectinas, integrinas e moléculas de adesão da família das imunoglobulinas (Ig) (MOGENSEN, 2009). Nas vênulas pós-capilares dos tecidos inflamados, as selectinas presentes nas células endoteliais (E- Pselectinas), interagem com ligantes presentes nos leucócitos (L-selectina), fazendo com que essas células trafeguem em menor velocidade e rolem sobre o endotélio (LANGER; CHAVAKIS, 2009). Esse rolamento faz com que os leucócitos interajam com quimiocinas liberadas e ancoradas na superfície do endotélio e essa interação leva a uma mudança na conformação das integrinas ICAMs e VCAM-1 que por sua vez, aumentam sua afinidade pelos seus ligantes presentes nos leucócitos LFA-1 (ITGAL/ ITGB2), Mac-1 (ITGAM/ ITGB2) e VLA-4, resultando na firme adesão e apreensão dessas células ao endotélio. Após adesão, os leucócitos espraiam sobre a superfície endotelial e finalmente deixam os vasos através da interação com moléculas da família das imunoglobulinas como PECAM-1 e JAM-A (COUSSENS; WERB, 2002; LEY et al., 2007; LUSTER; ALON; ANDRIAN, 2005). A expressão das moléculas ICAM-1 e VCAM-1 pode ser induzida pela ação de algumas citocinas como o TNF- $\alpha$ e IL-1 $\beta$ (DINARELLO, 2009; SUMAGIN; LOMAKINA; SARELIUS, 2008; TRACEY et al., 2008).

A matriz extracelular (ECM) também tem influência no comportamento celular do tecido inflamado. Ensaios in vitro têm demonstrado que metaloproteinases (MMPs) podem clivar uma grande quantidade de substratos e isso nos leva a acreditar que estas podem degradar substratos da ECM para permitir a passagem de células infiltrantes (SOROKIN, 2010).

As MMPs são endoproteases primeiramente conhecidas por degradar componentes de matriz extracelular participando de processos de remodelação, como morfogênese, reparo tecidual e angiogênese, mas recentes pesquisas demonstram suas atividades de uma forma mais ampla, implicando-as com participação no processo inflamatório e na progressão de tumores. Sua expressão é regulada por fatores como citocinas pró-inflamatórias, fatores de crescimento e hormônios e não está expressa em tecidos saudáveis (HINSBERGH; KOOLWIJK, 2008; LINT; LIBERT, 2006; MURPHY; NAGASE, 2008). A relação das MMPs com o processo inflamatório tem sido largamente estudada e esses estudos mostram a 
ação dessas proteases no controle da atividade de várias quimiocinas e citocinas, e no rompimento das junções aderentes entre as células influenciando no processo de migração celular (PARKS; WILSON; LOPEZ-BOADO, 2004).

Quando os leucócitos atingem o tecido injuriado, eles se tornam ativados, seja por contato com microrganismos ou por ação de citocinas secretadas pelas células residentes. A produção de espécies reativas do oxigênio (ROS) e nitrogênio (RNS), proteases e fatores de crescimento por neutrófilos e macrófagos no local da lesão, levam à destruição tecidual, assim como a proliferação de fibroblastos, que leva a uma aumentada produção de colágeno e consequente fibrose (CHEN; NUÑEZ, 2010; MEDZHITOV, 2008).

A inflamação estéril pode ser mais maléfica do que benéfica por que o mecanismo estimulante pode não ser danoso e assim sendo, fica difícil avaliar se a resposta está sendo útil ou não. As partículas estéreis, por exemplo, na maioria das vezes não são prejudiciais e em sua maioria a resposta inflamatória falha em eliminá-las. Nesse caso a resposta imune é estimulada de forma não adequada e a inflamação consequente pode causar danos colaterais graves ao hospedeiro como doenças agudas e dano tecidual. Se não resolvida, pode ainda desencadear resposta inflamatória crônica com dano tecidual grave e fibrose, e consequente desenvolvimento de diversos tipos de doenças (ROCK et al., 2010).

\subsection{CITOCINAS NO INÍCIO DA RESPOSTA INFLAMATÓRIA}

A IL-1 $\beta$ é conhecida por ser uma importante citocina pró-inflamatória e sua produção é em parte, dependente de um complexo multiprotéico denominado de inflamassoma. Existem vários tipos de inflamassomas e estes são identificados de acordo com o PRR contido nele. Um dos inflamassomas que tem sido descrito por reconhecer componentes não microbianos da inflamação é o NLRP3 ou NALP3. Em uma de suas vias, a ativação de NALP3 leva à ativação da caspase 1 , que por sua vez cliva a pro-interleucina IL-1 $\beta$ em sua forma biologicamente ativa (CHEN; NUÑEZ, 2010). Sua função principal é regular resposta de fase aguda ao dano tecidual, seja por agentes infecciosos ou não infecciosos. Junto com o TNF-a, são considerados os maiores mediadores das respostas inflamatórias (WEBER; WASILIEW; KRACHT, 2010). 
Inúmeros estudos têm demonstrado um papel importante para a citocina IL-1 $\beta$ na geração de uma resposta inflamatória neutrofílica a diversas partículas estéreis e à morte celular. Um exemplo desses estudos mostrou que a neutralização de IL-1 $\beta$ com anticorpos inibiu a resposta inflamatória neutrofílica em camundongos à morte celular e a cristais de urato monosódio (ROCK et al., 2010).

As citocinas TNF- $\alpha$ e IL-6 também têm papel importante no início da resposta. O TNF- $\alpha$ pode ser expresso tanto na membrana celular como na forma solúvel. Pode ser produzido por inúmeras células e é extremamente importante para diferenciação, proliferação e sobrevivência de células imunes. O TNF- $\alpha$ liga-se a dois tipos de receptores, o TNFR1 e o TNFR2 (TRACEY et al., 2008; WALLIS, 2008). O primeiro está expresso em quase todas as células do organismo e o segundo, é mais comumente encontrado em células do sistema hematopoiético. Os efeitos da ligação do TNF- $\alpha$ ao seu receptor podem levar à ativação do fator de transcrição NFkB1, que controla um grande número de genes inflamatórios, ou à apoptose dependendo do estado metabólico da célula. A produção de TNF- $\alpha$ por macrófagos pode ser induzida por uma série de estímulos como bactérias, vírus, complexos imunes, citocinas, traumas entre outros (BALKWILL, 2009; TRACEY et al., 2008). Esse agente é considerado um dos maiores indutores da inflamação, por entre outras funções, estimular a síntese de outras citocinas responsáveis pela cascata pró-inflamatória (PARAMESWARAN; PATIAL, 2010).

A IL-6 é uma citocina pleiotrópica, podendo ter ação pró ou anti-inflamatória. É produzida por macrófagos, fibroblastos e células endoteliais de tecidos inflamados sendo induzida principalmente por LPS, IL-1 $\beta$, TNF- $\alpha$ e alguns interferons. É um mediador importante no estímulo de proteínas de fase aguda e por atuar na transição do recrutamento de neutrófilos para macrófagos pelo estímulo da produção de CCL2 (MCP-1), um potente quimiotático de monócitos (DESHMANE et al., 2009; GABAY, 2006; MÖLLER; VILLIGER, 2006). A IL-6 liga-se a seu receptor IL-6R que pode ser expresso na membrana de diversos tipos celulares e também na forma solúvel e essa combinação IL-6/IL-6R solúvel é comumente encontrada em exsudatos inflamatórios ricos em neutrófilos (KAPLANSKI et al., 2003). Ainda, a IL-6 mostrou ser extremamente importante para o recrutamento de monócitos em um modelo de peritonite aguda, onde nos camundongos wild-type houve infiltração 
neutrofílica seguida de infiltração monocítica e nos camundongos knock out para o gene da $/ 16$ o infiltrado celular se restringiu aos neutrófilos (HURST et al., 2001).

Todas as três moléculas têm sido alvo de estudos para a aplicação clínica, no tratamento de algumas patologias inflamatórias e autoimunes nas quais os seus bloqueios têm melhorado o prognóstico (MÖLLER; VILLIGER, 2006).

\subsection{RESOLUÇÃO OU CRONIFICAÇÃO DA RESPOSTA INFLAMATÓRIA}

Após o estímulo inflamatório ser eliminado o processo de resolução se inicia. A síntese de mediadores pró-inflamatórios irá cessar e junto com a liberação de fatores que previnem o tráfego de neutrófilos para os tecidos, a resposta inflamatória tende a ser resolvida. As células locais voltam para a circulação sistêmica ou morrem por apoptose (programa de morte celular induzida) e são fagocitadas por macrófagos residentes e/ou recrutados (LAWRENCE; GILROY, 2007). Moléculas da família do TNF- $\alpha$ sinalizando através do receptor de TNF tipo 1 geram forte sinal para apoptose das células (CHAPLIN, 2010).

A resolução da inflamação é um processo fortemente regulado por uma série de mediadores como citocinas, quimiocinas e seus receptores e é descrito como um processo ativo com ativação de programas endógenos que vão induzir o término do processo (SERHAN, 2004). Isso inclui vários mecanismos descritos. Um modelo de mediador pró-resolução são as lipoxinas, que passam a ser sintetizadas no lugar das prostaglandinas. Elas têm ação anti-inflamatória, impedindo o recrutamento de neutrófilos e recrutando macrófagos, que são os principais componentes da resolução e reparo, pela fagocitose dos restos celulares. Outros eicosanóides como protectinas e resolvinas também têm demonstrado seu papel na resolução (SERHAN, 2004; SERHAN et al., 2007; SERHAN; SAVILL, 2005,).

A própria morte celular por apoptose é um mecanismo que estimula a resolução. Trabalhos como o de Fadok et al. (1998) e Huynh, Fadok e Henson (2002), sugerem que células apoptóticas fagocitadas por macrófagos, podem desestimular a inflamação pela liberação de TGF- $\beta$ e outros mediadores antiinflamatórios. O TGF- $\beta$ ou fator estimulador do crescimento $\beta 1$ é uma citocina antiinflamatória que tem papel importante na manutenção da homeostase tecidual, que facilita a resolução e induz reparo, regulando negativamente o recrutamento e 
ativação de leucócitos, recrutando fibroblastos, e estimulando a síntese dos componentes de matriz extracelular (WAHL, 1994). Os efeitos anti-inflamatórios dessa citocina têm sido enfatizados pelo fato de que camundongos knockout para o gene do Tgfb desenvolvem resposta inflamatória excessiva com morte precoce e doenças autoimunes (KULKARNI et al., 1993; LI et al., 2006).

Os mecanismos efetores da imunidade inata para destruir agentes indesejáveis são extremamente potentes e, como citado anteriormente, podem intensificar o dano tecidual causando maiores patologias. Em particular, a resposta aguda neutrofílica é considerada uma das principais causas desses eventos, como observados em estudos onde a depleção ou bloqueio dessas células diminuiu consideravelmente o desenvolvimento de algumas patologias como derrame e a hepatotoxicidade induzida por drogas (MCDONALD, KUBES, 2011; ROCK et al., 2010).

Portanto, se o processo de resolução e reparo por algum motivo falhar, o processo inflamatório pode persistir, e então levar a uma inflamação crônica, que é o caso de muitas doenças hoje conhecidas, com o componente inflamatório como causa agravante, sejam doenças autoimunes como artrite reumatóide (SWEENEY; FIRESTEIN, 2004), infecções não resolvidas como parasitoses (RODRIGUES et al., 2009) ou tumores malignos provenientes de mutações genéticas (VISSER; EICHTEN; COUSSENS, 2006). A deficiência de um regulador negativo da inflamação, assim como a persistência de citocinas e quimiocinas inflamatórias no local, são fatores críticos para o desenvolvimento de uma doença crônica, que é proveniente da estimulação contínua da resposta imune inata, tendo como principal característica uma intensa infiltração de células mononucleares (COUSSENS; WERB, 2002; LAWRENCE; GILROY, 2007).

Os leucócitos e fagócitos continuamente estimulados produzem espécies reativas do oxigênio e do nitrogênio, que na tentativa de conter a infecção ou injúria, danificam as células hospedeiras podendo causar mutações no DNA e podendo muitas vezes levar ao desenvolvimento de tumores malignos. Por isso, algumas doenças inflamatórias crônicas aumentam a predisposição ao desenvolvimento de cânceres como é o caso de doenças inflamatórias do intestino (SZKARADKIEWICZ, 2009), hepatite $C$ no fígado, e infecção crônica por Helicobacter pylori, que é a principal causa de câncer no estômago (COUSSENS; WERB, 2002; ERNST, 2000). 
Um grande progresso tem sido feito para se entender os mecanismos celulares e moleculares que envolvem as respostas inflamatórias agudas ou crônicas, mas muito pouco é conhecido sobre controle genético dessas respostas. Estudos de associação genômica têm sido capazes de identificar SNPs (marcadores de polimorfismos de nucleotídeo único ou Single Nucleotide Polymorfism) associados a uma variedade de doenças comuns como o câncer de próstata, câncer de mama e diabetes e essa identificação tem permitido aos geneticistas, um melhor entendimento das variantes genéticas que tem um papel na susceptibilidade ou resistência a essas e outras desordens clínicas (HUNTER; CRAWFORD, 2008). O laboratório de Imunogenética do Instituto Butantan tem como linha de pesquisa identificar os genes que afetam a intensidade da resposta inflamatória aguda e compreender os mecanismos celulares e moleculares da inflamação, assim como, correlacionar esse fenótipo com a susceptibilidade ou resistência a várias doenças inflamatórias experimentais, como o desenvolvimento de artrite reumatóide (VIGAR et al., 2000) e carcinoma de pele (BIOZZI et al., 1998) e de pulmão (MARIA et al., 2003).

\subsection{AS LINHAGENS AIRMAX E AIRMIN}

Para esse estudo genético, o laboratório desenvolve e mantém linhagens de camundongos que foram geneticamente selecionados para a máxima (AIRmax) ou mínima (AIRmin) reatividade inflamatória aguda, e esses camundongos são utilizados em uma série de experimentos.

Essas linhagens foram produzidas, por seleção genética bidirecional, a partir de uma população $\mathrm{F} 0$, proveniente do cruzamento entre 8 linhagens isogênicas. As 8 linhagens escolhidas foram: A/J, DBA/2J, P/J, SWR/J, SJR/J, CBA/J, BALB/cJ e C57BL/6J baseadas nas origens e características de resistência ou susceptibilidade a infecções e neoplasias. Essa população F0 foi então, constituída teoricamente de uma combinação de $12,5 \%$ do genoma de cada uma das linhagens parentais (IBAÑEZ et al., 1992; RIBEIRO, 1994; STIFFEL et al., 1990).

O fenótipo da inflamação foi medido pelo influxo local de leucócitos e pelo extravasamento proteico após 24 horas de uma injeção subcutânea de poliacrilamida (Biogel) no dorso dos animais. O Biogel é uma solução insolúvel, 
inerte e não imunogênica que age somente como material estranho e, portanto induz uma resposta inflamatória local e estéril (IBAÑEZ et al., 1992; STIFFEL et al., 1990). Durante o processo de seleção, os animais foram caracterizados fenotipicamente, e aqueles com maior ou menor capacidade inflamatória foram separados e cruzados entre si prosseguindo os acasalamentos até alcançar a máxima separação fenotípica interlinhagens. Os animais foram cruzados, sempre com o cuidado de não acasalar irmãos e primos para evitar aumento de consanguinidade.

Figura 1 - Divergência entre as linhagens AIR quanto à resposta inflamatória
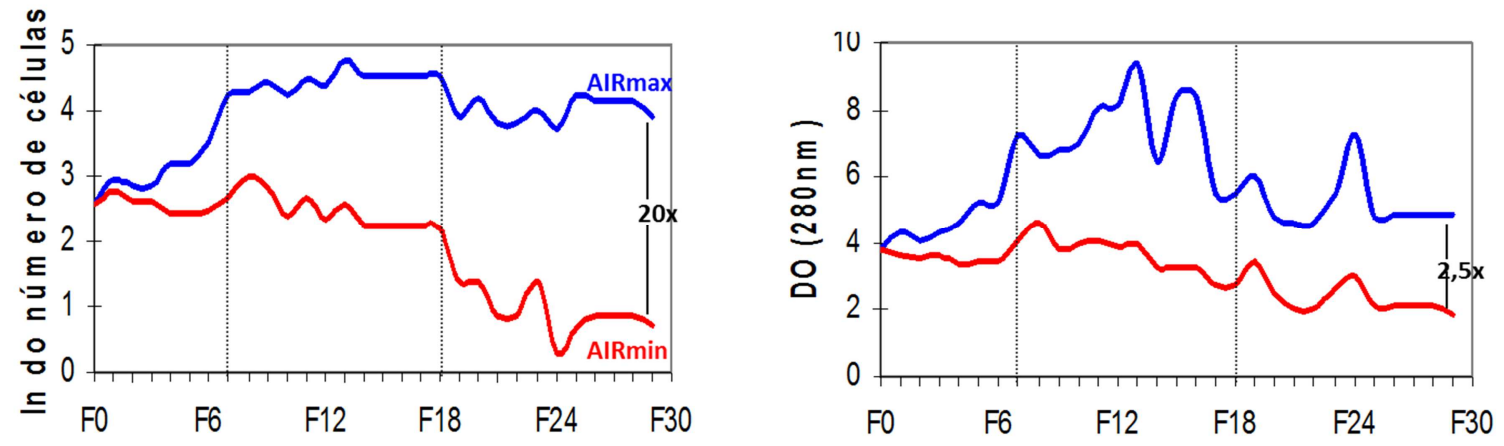

Gráfico representativo da divergência entre as linhagens AIR quanto ao número médio de células infiltrantes e extravasamento proteico no local de aplicação de Biogel

Fonte: Modificado de Biozzi et al. (1998). Com permissão.

O ponto máximo de separação fenotípica entre as duas linhagens revelou que a intensidade da reação inflamatória aguda (AIR) é dependente do efeito aditivo de vários genes de baixa penetrância, ou seja, de uma regulação poligênica. Assim, ao final do processo de seleção, considerou-se que os alelos para máxima resposta inflamatória aguda foram fixados em homozigose nos animais AIRmax, e os alelos para mínima resposta inflamatória aguda, nos animais AIRmin, porém, mantendo um fundo genético heterogêneo nesses animais (IBAÑEZ et al., 1992). Atualmente a divergência das linhagens é cerca de 25 e 2,5 vezes de diferença para leucócitos (com predominância de células polimorfonucleares) e proteínas, respectivamente. Foram estimados cerca de 7 a 11 loci reguladores para o caráter selecionador (BIOZZI et al., 1998).

De acordo com Ribeiro et al. (2003), essa diferença interlinhagens a favor dos animais AIRmax, é consequência do aumento da produção de fatores quimiotáticos atraentes de neutrófilos no local de aplicação do Biogel, maior produção dessas 
células na medula óssea e maior resistência dessas células à apoptose no local de extravasamento.

A capacidade inflamatória foi testada em animais também desenvolvidos no nosso laboratório, que diferem na alta ou baixa capacidade de produzir anticorpos, e o resultado demonstrou um nível variável de inflamação, independentemente da resposta imune, provando que a capacidade de produção de anticorpos (imunidade adquirida) e inflamatória (imunidade inata) são controladas por genes independentes (RIBEIRO, 1994).

Esse modelo animal demonstrou inúmeras diferenças de resposta frente a patologias, como no caso de infecção por Salmonella Typhimurium (ARAÚJO et al., 1998) e indução química de carcinogênese de pele por DMBA (iniciador) e TPA (promotor), onde os AIRmax se mostraram mais resistentes do que os animais AIRmin (BIOZZI et al., 1998) e doença autoimune como artrite induzida por pristane, onde nesse caso os animais AIRmin foram os mais resistentes (VIGAR et al., 2000). Um perfil distinto entre as duas linhagens também pôde ser observado quando os animais foram desafiados com outros agentes inflamatórios como a carragenina e o zymosan (VASQUEZ-BRAVO, 1996) e o veneno de Bothrops jararaca (CARNEIRO et al., 2002), além de uma distinta resposta de regeneração tecidual (DE FRANCO et al., 2007), demonstrando claramente uma relação da capacidade inflamatória com cada um desses fenótipos.

Até o presente momento dois dos 11 QTLs (Quantitative Trait Loci) estimados para o fenótipo de seleção (número de células infiltrantes) foram detectados através da análise de polimorfismos com marcadores SNP. Um desses loci chamado de Irm1 foi encontrado no cromossomo 7 (VORRARO et al., 2010). Este locus contém cerca de 230 genes e mostrou estar envolvido com o número de células infiltradas no exsudato e com a produção de IL-1 $\beta$ ex vivo. O outro locus, o Irm2 foi mapeado no cromossomo 5 e também mostrou estar envolvido com ambos os fenótipos (GALVAN et al., 2011). Além disso, o trabalho de Galvan et al. (2011) detectou outros QTLs sugestivos nos cromossomos 2, 4, 5, 6, 7, 11, 13 e 16 para o número de células infiltrantes e nos cromossomos $1,5,7,8,10,13,14$ e 17 para a produção de IL-1 $\beta$. Dois SNPs mapeados no locus Irm1, que foram altamente associados com a produção de IL-1 $\beta$, apareceram também entre os SNPs sugestivos para o número de células infiltrantes. A detecção desses QTLs envolvidos no controle da resposta 
inflamatória aguda foi realizada por ensaio de co-segregação em intercruzamentos de camundongos das linhagens AIRmax X AIRmin (segregantes F2), por avaliação dos níveis variáveis de resposta inflamatória.

A resposta inflamatória aguda (AIR), divergente nessas linhagens está bem estabelecida, e foi baseada em inúmeros experimentos mostrando diferenças quanto à produção de células, produção de citocinas, de quimiocinas, expressão de genes entre outros fenótipos. No entanto diferenças na resposta inflamatória tardia ou crônica ao Biogel ainda não foi descrita.

Baseado nessas informações, uma questão nos veio em mente: será que genes que interferem com a AIR podem afetar o desenvolvimento de uma inflamação crônica às partículas de poliacrilamida? Para responder a essa pergunta nós procuramos avaliar primeiramente o exsudato local quanto a diferenças no infiltrado celular e presença de algumas citocinas inflamatórias. Posteriormente, nós avaliamos a expressão gênica global e relativa e as condições histológicas do tecido subcutâneo de ambas as linhagens, todos os experimentos sendo realizados após um período agudo de 48 horas e um período que nós consideramos crônico, de 30 dias. Com esses resultados, nós procuramos fazer uma associação dos fenótipos encontrados nas linhagens com a expressão de genes na pele e da expressão desses genes com as regiões previamente mapeadas. Como muitos trabalhos com doenças inflamatórias crônicas têm demonstrado que mediadores envolvidos com o início de respostas inflamatórias, podem ter participação importante na progressão e manutenção de tais doenças, nós acreditamos que tais genes podem não estar somente envolvidos com o desenvolvimento de uma resposta inflamatória aguda, mas que também podem ter uma participação importante no controle genético de uma resposta inflamatória crônica. 


\section{OBJETIVO}

Caracterizar fenótipos adicionais nas linhagens AIRmax e AIRmin que podem estar relacionados com QTLs envolvidos na regulação da resposta inflamatória aguda e verificar se o processo de seleção que modificou essa resposta nas linhagens foi capaz de afetar o desenvolvimento de uma resposta inflamatória crônica às partículas de Biogel.

\subsection{OBJETIVOS ESPECÍFICOS}

a) Quantificar e diferenciar as células infiltradas no exsudato formado pelo Biogel nas linhagens AIR após um período agudo de 48 horas e um período crônico de 30 dias;

b) verificar e quantificar a presença de citocinas inflamatórias no exsudato inflamatório e no soro das linhagens;

c) pesquisar comparativamente a expressão gênica global e relativa dos mRNAs no tecido subcutâneo dos animais AIRmax e AIRmin;

d) analisar comparativamente os eventos celulares que ocorrem no tecido subcutâneo das linhagens após aplicação de Biogel pela da observação macroscópica e microscópica do tecido. 


\section{MATERIAIS E MÉTODOS}

\subsection{ANIMAIS}

Foram utilizados camundongos machos e fêmeas das linhagens heterogêneas AIRmax e AIRmin com cerca de 2 a 4 meses de idade. Esses animais são mantidos em biotério próprio do laboratório de Imunogenética do Instituto Butantan e os experimentos para este projeto foram aprovados pela Comissão de Ética no Uso de Animais do Instituto Butantan (CEUAIB - protocolo $n^{\circ}$ 652/09) e da Universidade de São Paulo (CEUA - protocolo $n^{\circ} 42$, fls.86 do livro 02 ).

\subsection{INDUÇÃO DO PROCESSO INFLAMATÓRIO AGUDO E CRÔNICO}

A indução da resposta inflamatória aguda e crônica foi feita com microesferas de poliacrilamida, chamadas de Biogel P-100 (Biorad Laboratories, Inc, Hercules, CA, Estados Unidos). Três gramas de Biogel foram hidratadas em $300 \mathrm{ml}$ de PBS, previamente aquecido a $90{ }^{\circ} \mathrm{C}$. A suspensão foi submetida à pressão negativa (vácuo) para a retirada de gás retido dentro das partículas. Foi então, autoclavada durante 20 minutos a $120^{\circ} \mathrm{C}$ e após, lavada com salina estéril três vezes. Após a última lavagem, foi acrescentado o volume de salina estéril correspondente à metade do volume ocupado pelo Biogel hidratado. Os animais foram previamente depilados na região dorsal e então foi aplicado por via subcutânea $0,75 \mathrm{ml}$ dessa suspensão de Biogel P-100.

\subsection{RECUPERAÇÃO DO EXSUDATO PARA CONTAGEM CELULAR}

Após o tempo estipulado de 48 horas e 30 dias da injeção com Biogel, foi injetado no compartimento subcutâneo $1 \mathrm{ml}$ de PBS contendo $20 \mathrm{U} / \mathrm{ml}$ de heparina. O líquido foi aspirado para dentro da seringa e re-injetado para uma "lavagem" do local. Após esse procedimento, o conteúdo da seringa foi esgotado em tubo plástico e deixado em repouso por três minutos para sedimentação das partículas de Biogel. Uma alíquota de $500 \mu \mathrm{l}$ foi transferida para outro tubo contendo $2 \mathrm{ml}$ de PBS (diluição 1:5) e deixado em repouso por mais 2 minutos para sedimentar as 
partículas restantes. Essa suspensão celular foi em seguida, diluída na proporção 1:5 (0,1+0,4 ml) em Azul de Metileno/Ácido acético a 1\%. O número total de células foi determinado por contagem em Câmara de Malassez. As populações celulares presentes no exsudato foram ajustadas para a concentração de $5 \times 10^{4}$ em $300 \mu \mathrm{lde}$ PBS e determinadas por contagem diferencial em preparações histológicas feitas no aparelho Cytospin 4 (Thermo Scientific, Wilmington, DE, Estados Unidos) e coradas com Panótico Rápido (Laborclin, Pinhais, PR, Brasil).

\subsection{DOSAGEM DE CITOCINAS POR ENSAIO DE ELISA}

As citocinas inflamatórias IL-1 $\beta$, IL-6, TNF- $\alpha$ e a quimiocina CCL2 foram quantificadas por ensaio colorimétrico de ELISA (BD Biosciences, San Diego, CA, Estados Unidos), utilizando o exsudato inflamatório local, produzido pela injeção do Biogel nos períodos de 48 horas e 30 dias. $O$ exsudato foi recuperado injetando no compartimento subcutâneo $1 \mathrm{ml}$ de PBS. Para os animais controles, foi feito um "air punch" pela injeção de $3 \mathrm{ml}$ de ar no dorso subcutâneo e em seguida foi injetado $0,75 \mathrm{ml}$ de salina. Após 48 horas, foi injetado $1 \mathrm{ml}$ de PBS no compartimento subcutâneo e a salina foi coletada da mesma forma como feito para os animais tratados com Biogel.

Placas de microtitulação de poliestireno (96 poços - NUNC/Maxisorp) foram sensibilizadas com anticorpos específicos de captura diluídos em tampão carbonato de sódio $\mathrm{pH}$ 9,5 ou fosfato de sódio $\mathrm{pH}$ 6,5 e incubados a $4{ }^{\circ} \mathrm{C}$ overnight. Após esse período as placas foram lavadas com PBS tween $0,05 \%$. Os poços foram então bloqueados com PBS 10\% soro fetal e incubados por 1 hora em temperatura ambiente. Depois a placa foi lavada quatro com PBS tween e os recombinantes respectivos adicionados em diluições seriadas, e as amostra adicionadas, em duplicatas e incubadas em temperatura ambiente por duas horas. Os poços foram lavados novamente com PBS tween. Após lavagem adicionamos o anticorpo secundário (de deteç̧ão) diluído, e incubamos por uma hora em temperatura ambiente e depois lavamos oito vezes com PBSt. Adicionamos a avidina conjugada a peroxidase na diluição de 1:250 em PBS 10\% soro fetal. A placa então foi incubada 30 minutos em temperatura ambiente e depois lavada novamente com PBSt. Depois de adicionado o substrato TMB e peróxido de hidrogênio, incubamos a 
placa por cerca de 30 minutos em temperatura ambiente. A reação foi bloqueada com ácido sulfúrico $\left(\mathrm{H}_{2} \mathrm{SO}_{4}\right) 2 \mathrm{~N}$ e a leitura feita em leitor de ELISA com filtros de 450 $\mathrm{nm}$ e $570 \mathrm{~nm}$.

\subsection{BIOPLEX}

O ensaio para a detecção de citocinas com o Bioplex foi feito com soro de animais AIRmax e AIRmin controle ou sangrados após 48 horas ou 30 dias da injeção de Biogel com o kit Milliplex®map (Millipore Corporation, Billerica, MA, Estados Unidos) e foi usado para testar a presença de 8 citocinas: IL-1 $1 \beta$, TNF- $\alpha$, IL6, CXCL2, GM-CSF, IL-17, IL-10 e TGF- $\beta$.

Essa técnica é baseada na captura dos analitos presentes nas amostras, por beads diferentemente coradas e revestidas com um anticorpo específico de captura. Após o analito presente na amostra ser capturado pela bead, um anticorpo de detecção biotiniliado é introduzido. A reação é incubada com um conjugado Streptavidina-PE. As microesferas passam então por um laser que permite identificar cada microesfera e quantificar os resultados.

Em placas de filtro de microtitulação, foi pipetado $200 \mu \mathrm{l}$ do tampão de lavagem em cada poço. A placa foi selada e colocada no agitador por 10 minutos em temperatura ambiente $\left(20-25^{\circ} \mathrm{C}\right)$. Após, o tampão foi removido por vácuo. $25 \mu \mathrm{l}$ da amostra padrão e do tampão de ensaio foram pipetados nos poços apropriados. 25 $\mu \mathrm{l}$ da solução matriz foram adicionados em todos os poços da placa e $25 \mu \mathrm{l}$ de cada amostra adicionada em seu respectivo poço. Após a adição das beads (25 $\mu \mathrm{l})$, a placa foi selada e incubada com agitação overnight a $4^{\circ} \mathrm{C}$. Após esse período, o fluído foi removido por vácuo e a placa foi lavada 2 vezes com tampão de lavagem. Foram então adicionados $25 \mu \mathrm{l}$ do anticorpo de detecção em cada poço. A placa foi selada e incubada com agitação por 1 hora em temperatura ambiente. $25 \mu$ do conjugado Streptavidina-PE foram pipetados em cada poço e a placa incubada com agitação por mais 30 minutos em temperatura ambiente e após, lavada e filtrada por vácuo. $150 \mu \mathrm{l}$ do fluído de revestimento foram adicionados $\mathrm{e}$ as beads ressuspendidas em agitador por 5 minutos. A leitura da placa foi feita no aparelho Bio-plex e os dados analisados no Bio-plex Manager Software versão 4.0 (Bio-Rad 
Laboratories, Inc, Hercules, CA, Estados Unidos). A curva padrão variou de 3,2 $\mathrm{pg} / \mathrm{ml}$ a $10000 \mathrm{pg} / \mathrm{ml}$.

\subsection{EXTRAÇÃO DE RNA TOTAL DO TECIDO SUBCUTÂNEO DOS CAMUNDONGOS}

A extração do RNA total foi feita pelo RNAspin Mini RNA isolation kit (Ge Healthcare, Little Chalfont, Buckinghamshire, Reino Unido). Cerca de aproximadamente $30 \mathrm{mg}$ do tecido que esteve em contato com o Biogel, foram isolados em tubo do tipo ependorf. A este tubo foram adicionados $350 \mu$ de tampão RA1 e 3,5 $\mu$ l de $\beta$-mercaptoetanol e o tecido foi picotado com uma tesoura. O lisado foi transferido para uma unidade do mini filtro RNAspin e centrifugado a $11000 \mathrm{~g}$ por 1 minuto. A coluna foi descartada e o filtrado foi transferido para um novo microtubo de coleta de $1,5 \mathrm{ml}$. A esse tubo foram adicionados $350 \mu \mathrm{l}$ de etanol $70 \%$ e passado no vórtex. As amostras foram homogeneizadas, passadas por uma nova coluna e centrifugadas por 30 segundos a $8000 \mathrm{~g}$. A coluna foi retirada do tubo e transferida para um novo tubo coletor. Então, $350 \mu \mathrm{l}$ de MDB (tampão de dessalinização da membrana) foram adicionados e centrifugados a $11000 \mathrm{~g}$ por 1 minuto. A coluna foi retirada, o sobrenadante descartado e a coluna colocada em um novo tubo coletor. $10 \mu \mathrm{l}$ de DNase foram diluídos em $90 \mu \mathrm{l}$ de tampão de DNAse e $95 \mu \mathrm{l}$ do mix dessa reação foram aplicados na coluna e incubados à temperatura ambiente por 15 minutos. Depois, foram adicionados $200 \mu \mathrm{l}$ de tampão RA2 na coluna RNAspin, centrifugado por 1 minuto a $11000 \mathrm{~g}$ e colocado a coluna dentro de um novo tubo coletor. $600 \mu \mathrm{l}$ de tampão RA3 foram aplicados na coluna, centrifugado por mais 1 minuto a $11000 \mathrm{~g}$, o sobrenadante descartado e a coluna colocada de volta dentro do tubo coletor. Foram adicionados $250 \mu$ de tampão RA3 novamente na coluna e centrifugado por 2 minutos a $11000 \mathrm{~g}$ para secar a membrana completamente. A coluna foi colocada dentro de um microtubo livre de nuclease de 1,5 ml. O RNA foi eluído em $50 \mu \mathrm{l}$ de $\mathrm{H}_{2} \mathrm{O}$ livre de RNase e centrifugado a 11000 g por 1 minuto. A coluna foi descartada e o RNA eluído foi estocado a $-80{ }^{\circ} \mathrm{C}$. A integridade das bandas foi observada em gel de agarose e a concentração medida em espectrofotômetro pela leitura da densidade ótica (D.O.). 


\subsection{SÍNTESE DO cDNA}

A síntese de cDNA foi feita de uma reação de transcrição reversa a partir do RNA total purificado. Assim, foi feito uma mistura com $1 \mu \mathrm{l}$ de dNTP, $1 \mu \mathrm{l}$ de oligo(dT) e $2 \mu \mathrm{l}$ de água. Esse mix foi adicionado às amostras contendo $0,5 \mu \mathrm{g}$ de RNA em $10 \mu \mathrm{l}$. A mistura foi homogeneizada e submetida à temperatura de $65^{\circ} \mathrm{C}$ por 5 minutos. Após esse período, os tubos foram colocados por 1 minuto no gelo e depois adicionados $4 \mu \mathrm{l}$ de tampão específico $5 \mathrm{X}$ concentrado $(250 \mathrm{mM}$ Tris- $\mathrm{HCl} \mathrm{pH}$ 8,3, $375 \mathrm{mM} \mathrm{KCL}$ e $15 \mathrm{mM}$ MgCl2), $1 \mu \mathrm{l}$ de DTT (0,1M) e $1 \mu \mathrm{l}$ da enzima Superscript

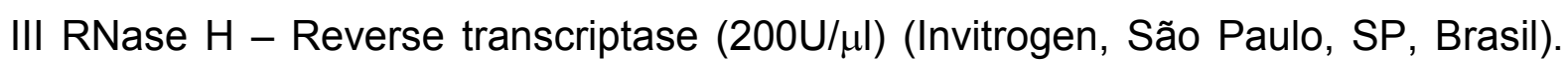
Essa mistura foi incubada a $50^{\circ} \mathrm{C}$ durante 50 minutos e mais 15 minutos a $70{ }^{\circ} \mathrm{C}$ para inativação. As reações foram incubadas em aparelho termociclador PTC 200 (MJ Research, St. Bruno, QC, Canadá).

As sondas iniciadoras ou primers utilizados para a amplificação dos CDNAs a partir dos mRNA das citocinas $111 \beta, \| 16, \operatorname{Tnf} \alpha, \operatorname{Tgf} \beta, C x c / 1, C x c / 2, C c / 2$, do receptor de quimiocina $C x c r 2$, da metaloproteinase $M m p 9$ e das moléculas de adesão ltgb2 e Vcam1, são descritos a seguir.

Quadro 1 - Sondas iniciadoras utilizadas na síntese do mRNA

\begin{tabular}{|l|l|l|}
\hline Primers & Sense & Anti-sense \\
\hline Il1 $\beta$ & TTGACGgACCCCAAAAGATG & TCTCACTGAAACTCAGCCGT \\
\hline Il6 & GTTCTCTGGGAAATCGTGGA & TGTACTCCAGGTAGCTATGG \\
\hline Tnfa & TCTCATCAGTTCTATGGCCC & GGGAGTAGACAAGGTACAAC \\
\hline Tgfb & ACCGCAACAACGCCATCTAT & GTAACGCCAGGAATTGTTGC \\
\hline Cxcl1 & TGAAGCTCCCTTGGTTCAGA & AGGTGCCATCAGAGCAGTCT \\
\hline Cxcl2 & CCTGGTTCAGAAATCATCCA & CTTTGGTTCTTCCGTTGAGG \\
\hline Cxcr2 & AGCCAAGAATCTCCGTAGCA & GCCCTACAACCTGGTTCTGT \\
\hline Ccl2 & GCCTGCTGTTCACAGTTGC & TCATTGGGATCATCTTGCTG \\
\hline Itgb2 & CAACATCCATGTGGAGGACA & TTCCAGATGACCAGGAGGAG \\
\hline Mmp9 & CGCTCATGTACCCGCTGTAT & CGCTCATGTACCCGCTGTAT \\
\hline Vcam1 & CCATGGAGCCTGTCAGTTTT & CTCTGGATCCTTGGGGAAA \\
\hline
\end{tabular}

Fonte: (FERNANDES, 2012) 


\subsection{ANÁLISE DA EXPRESSÃO GÊNICA GLOBAL}

Os reagentes utilizados para a preparação dos microarrays fazem parte da plataforma "GeneChip" Affymetrix mouse 1.0 ST bioarrays (Affymetrix, Inc, Santa Clara, CA, Estados Unidos) e foi dividido nas seguintes etapas: preparação do alvo, hibridação do alvo, lavagem e marcação dos arrays, escaneamento do array e análise de dados.

\subsubsection{Preparação do alvo}

Os Poly-A RNAs controles são fornecidos como concentrações estoque de 4 diferentes transcritos em concentrações seriadas. O tampão de diluição é fornecido com o kit para preparar as diluições apropriadas. Após feitas as 3 diluições necessárias dos RNAs controles, $2 \mu \mathrm{l}$ da terceira diluição foi adicionado a $1 \mu \mathrm{g}$ do RNA total para formar o mix RNA total/Controle Poly-A RNA. Em um tubo foi misturado $3 \mu \mathrm{l}$ do RNA total/Poly-A Controls Mix, 0,8 $\mu \mathrm{l}$ RiboMinus Probe (100 $\mathrm{pmol} / \mu \mathrm{l})$ e $20 \mu \mathrm{l}$ do tampão de hibridação com Betaine. Os tubos foram deixados a $70{ }^{\circ} \mathrm{C}$ por 5 minutos em termociclador e após esse período foram esfriados rapidamente colocando-os no gelo.

\subsubsection{Síntese do cDNA de fita simples}

Foi adicionado $1 \mu \mathrm{l}$ dos primers diluídos T7-(N)6 (500 ng/mL) a $4 \mu \mathrm{l}$ do RNA concentrado e deixado a $70{ }^{\circ} \mathrm{C}$ por 5 minutos e logo após a $4{ }^{\circ} \mathrm{C}$ por pelo menos 2 minutos. Em seguida foram adicionados $2 \mu \mathrm{l}$ do tampão de fita simples $5 \mathrm{X}, 1 \mu \mathrm{l}$ de $\operatorname{DTT}(0.1 \mathrm{M}), 0,5 \mu \mathrm{l}$ de dNTP $(10 \mathrm{mM}), 0,5 \mu \mathrm{l}$ do inibidor de RNase e $1 \mu \mathrm{da}$ Superscript II. A reação foi incubada a $25^{\circ} \mathrm{C}$ por 10 minutos, $42{ }^{\circ} \mathrm{C}$ por 60 minutos e $70{ }^{\circ} \mathrm{C}$ por 10 minutos. Após esse período a reação foi imediatamente levada a $4{ }^{\circ} \mathrm{C}$ por 2 minutos.

\subsubsection{Síntese do cDNA de fita dupla.}

Aos tubos da reação anterior foram adicionados 4,8 $\mu$ le $\mathrm{H}_{2} \mathrm{O}$ livre de RNAse, $4 \mu \mathrm{l}$ de $\mathrm{MgCl}_{2}(17.5 \mathrm{mM}), 0,4 \mu \mathrm{l}$ de dNTP Mix (10 mM), 0,6 $\mu$ l de DNA polymerase I e 
$0,2 \mu \mathrm{l}$ de RNase $\mathrm{H}$ totalizando $20 \mu \mathrm{l}$. A reação foi incubada em termociclador a $16{ }^{\circ} \mathrm{C}$ por 120 minutos sem aquecimento da tampa e mais 10 minutos a $70{ }^{\circ} \mathrm{C}$ com aquecimento da tampa. As amostras foram esfriadas a $4^{\circ} \mathrm{C}$ por 2 minutos.

\subsubsection{Síntese do cRNA e purificação}

A síntese do cRNA foi feita pela técnica de transcrição in vitro (reação IVT). Em um tubo separado foram misturados $5 \mu$ do tampão IVT (10X), $20 \mu \mathrm{l}$ de Mix IVT NTP e $5 \mu \mathrm{l}$ do Mix da enzima IVT. Esse conteúdo foi adicionado à reação anterior totalizando $50 \mu$ e incubado por 16 horas a $37^{\circ} \mathrm{C}$. O procedimento de purificação foi feito usando colunas de purificação GeneChip IVT cRNA Cleanup Kit (Affymetrix). $\mathrm{O}$ cRNA purificado foi submetido a uma análise de pureza e integridade no qual a concentração foi medida no aparelho de espectrofotometria NanoDrop 2000 (Thermo Scientific) e a integridade foi verificada no aparelho Bioanalyser 2100 (Agilent Technologies, Santa Clara, CA, Estados Unidos).

\subsubsection{Fragmentação do cRNA}

A uma concentração de $10 \mu \mathrm{g}$ em $20 \mu \mathrm{l}$ de cRNA, foram adicionados $10 \mu \mathrm{l}$ de $\mathrm{H}_{2} \mathrm{O}$ livre de RNase, 4,8 $\mu \mathrm{l}$ do tampão de fragmentação 10X, $10 \mu \mathrm{l}$ de UDG (10 U/ $\left.\mu \mathrm{l}\right)$ e $1 \mu \mathrm{l}$ de APE 1 (1,000 U/ $\mu \mathrm{l})$. A reação foi incubada a $37^{\circ} \mathrm{C}$ por 60 minutos, $93^{\circ} \mathrm{C}$ por 2 minutos e a $4^{\circ} \mathrm{C}$ por mais 2 minutos.

\subsubsection{Hibridação e Detecção com streptavidina}

Após transferir as amostras para um novo tubo foram adicionados 3,7 $\mu$ do oligonucleotídeo controle B2, $11 \mu$ do controle de hibridação 20X, $110 \mu$ do mix de hibridação $2 \mathrm{X}, 15,4 \mu \mathrm{l}$ de DMSO e $20 \mu \mathrm{l}$ de água livre de RNase. O coquetel de hibridação foi aquecido a $99^{\circ} \mathrm{C}$ por 5 minutos para desnaturação do cRNA e logo após a $45^{\circ} \mathrm{C}$ por 1 minuto. $200 \mu \mathrm{l}$ dessa reação foi injetada no Genechip Probe Array (Affymetrix) e em seguida colocada em agitador a 60 rpm e incubada por 17 horas. Após 17 horas de hibridação, os chips foram lavados e corados com 
estreptavidina-Cy5 para a detecção do sinal, no aparelho Fluidics Station 450 (Affymetrix) de acordo com o protocolo do fabricante.

\subsubsection{Análise dos dados obtidos}

Os dados foram analisados com "GeneArray Scanner-Affymetrix" (Affymetrix). Esta plataforma utiliza um sistema de detecção de cor única, baseado na incorporação indireta de apenas um fluorocromo para a marcação das amostras. Este sistema elimina resultados falsos decorrentes de parâmetros enzimáticos, que afetam a frequência de incorporação de fluorocromos distintos, ou relativos à sobreposição espectral de duas fluorescências. Os dados de expressão extraídos de cada microarray foram normalizados de acordo com os valores de fluorescência dos genes de expressão constitutiva, presentes nos chips como controles internos. Critérios para definição de valores para identificar genes diferencialmente expressos foram baseados em análise estatística, utilizando o programa de análise de significância de microarray (SAM) com FDR (False Discovery Rate) <5\%. Para aumentar o poder da análise estatística só foram considerados os genes pelo menos duas vezes diferentemente expressos. Para as análises de agrupamentos funcionais foi utilizado o software EASE (Expression Analysis Systematic Explorer) (EASE software, Portland, OR, Estados Unidos). Esse software permite que os genes diferencialmente expressos possam ser agrupados em "temas biológicos" de acordo com sua categoria funcional, sua localização cromossômica e sua representação em relação ao genoma total. O EASE calcula a sobre-representação dos genes em relação ao total de genes utilizados no ensaio e anotados dentro de cada sistema, tendo o "Gene Ontology" como padrão. Utilizamos a conversão da identificação dos genes para números do "LocusLink" para assegurar que cada gene fosse classificado apenas uma vez em cada categoria, já que em alguns sistemas (por exemplo, o GenBank) um único gene pode ter mais de uma identificação. Para calcular a significância das categorias, o programa utiliza um teste estatístico chamado "EASE score". Esse teste nada mais é do que um teste exato de Fisher modificado, onde é penalizada a categoria composta por poucos genes (chamadas "instáveis") em favor de categorias representadas por um maior número de genes, levando em consideração a perspectiva dos temas globais biológicos, minimizando a 
possibilidade de falsos-positivos. É, portanto, um teste mais restritivo (HOSACK et al., 2003).

\subsection{PCR EM TEMPO REAL}

A expressão dos mRNA para Tnf- $\alpha,\|1 \beta\| l 6,, C x c / 1, C x c / 2, C c / 2, C x c r 2, \operatorname{Tgf} \beta$, Mmp9, Itgb2 e Vcam1 extraídos do tecido subcutâneo dos animais AIRmax e AIRmin submetidos ao protocolo de inflamação foi avaliada através da quantificação dos respectivos cDNAs, por reações de PCR em tempo real (qPCR).

Cada amostra de cDNA foi adicionada contendo a sequência dos primers dos genes a serem pesquisados $(5 \mu \mathrm{M}) ; 12,5 \mu \mathrm{l}$ do Platinum SYBR Green qPCR Supermix-UDG (Invitrogen) e água para ajustar o volume final da reação em $25 \mu \mathrm{l}$ por tubo. As reações foram incubadas no aparelho Chromo 4 (MJ Research) e submetidas a uma fase inicial de incubação a $50^{\circ} \mathrm{C}$ por 2 minutos seguidos da fase de ativação da enzima a $95{ }^{\circ} \mathrm{C}$ por 5 minutos. As sequências alvo foram então amplificadas durante 40 ciclos constituídos de etapas sucessivas de desnaturação (95 ${ }^{\circ} \mathrm{C}$ por 20 segundos) e de anelamento ( $60^{\circ} \mathrm{C}$ por 35 segundos). A aquisição da fluorescência incorporada ao material dupla fita amplificado, a cada ciclo, foi efetuada na etapa final. A cada amostra foi atribuído um valor de Ct ("Cycle Threshold") referente ao número de ciclos necessários para que a fluorescência incorporada às fitas duplas amplificadas começasse a aumentar acima da fluorescência de fundo, ou seja, no início da fase logarítmica de amplificação a qual depende diretamente do número de cópias das sequências alvos que havia inicialmente em cada amostra.

Após a amplificação, o produto da reação foi submetido a uma fase "Melting" onde a temperatura variou de $55^{\circ} \mathrm{C}$ a $90^{\circ} \mathrm{C}$ e a fluorescência foi adquirida a cada $1^{\circ} \mathrm{C}$, registrando-se a temperatura de dissociação, ou desnaturação da dupla fita do material amplificado. Os dados foram adquiridos e analisados pelo programa Opticon Monitor Analysis Software 2.03 (MJ Research). A quantidade de RNA em cada amostra foi expressa através dos valores do "Cycle Threshold" (Ct). Para quantificar os resultados obtidos pelo RT-PCR alguns métodos são comumente utilizados, dentre eles o Método do Threshold Comparativo (GIULIETTI et al., 2001; LIVAK; SCHMITTGEN, 2001). Neste método fórmulas aritméticas são usadas para 
calcular níveis de expressão relativos com um calibrador, que pode ser uma amostra controle (ou amostra não tratada). A quantidade do gene alvo normalizado para um endógeno (gene constitutivo) e relativa à amostra calibradora é dada pela fórmula:

$$
\begin{gathered}
2{ }^{-{ }_{\Delta} \mathrm{Ct}}, \text { em que } \Delta \Delta \mathrm{Ct}=\Delta \mathrm{Ct} \text { (amostra) }-\Delta \mathrm{Ct} \text { (calibrador), e o } \Delta \mathrm{Ct} \text { é o } \mathrm{Ct} \text { do gene } \\
\text { alvo subtraído do } \mathrm{Ct} \text { do gene constitutivo }
\end{gathered}
$$

Assim, a equação representa a expressão normalizada do gene alvo, em uma amostra cuja quantidade é desconhecida, relativa à expressão normalizada da amostra calibradora. Neste trabalho o gene constitutivo utilizado foi a ciclofilina por ser uma proteína grandemente expressa na maioria dos tecidos (HASEL; SUTCLIFFE, 1990) e o nosso calibrador comum para todas as reações foi o animal AIRmin controle.

Figura 2 - Quantificação da expressão do gene ciclofilina
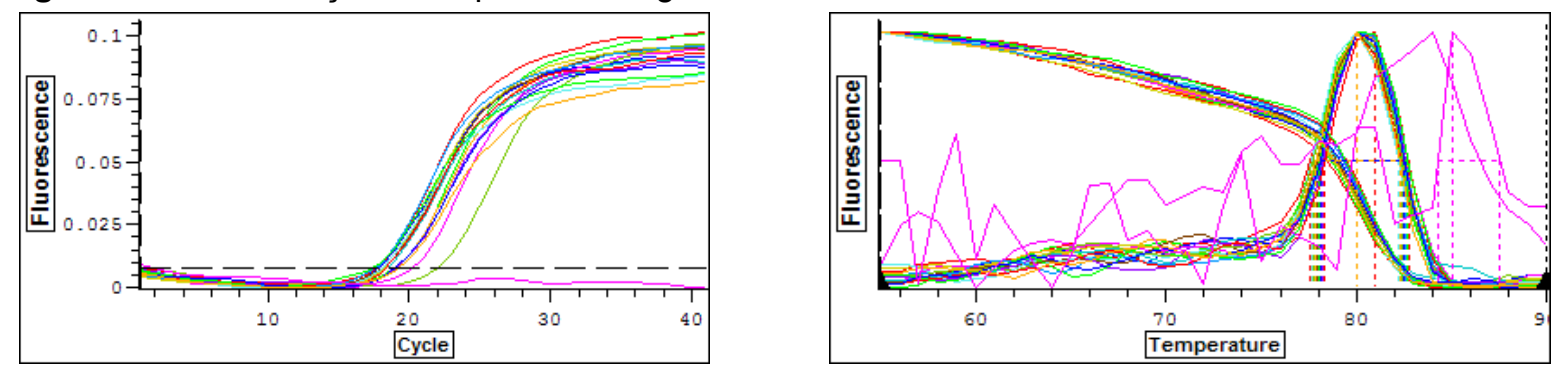

Expressão do gene ciclofilina em camundongos controles e experimentais das linhagens AIRmax e AIRmin coletados após 48 horas de injeção subcutânea de Biogel. Os gráficos mostram os respectivos "Cycle Threshold" (Ct), (à esquerda) e a curva de Melt (à direita). A curva em rosa clara indica o material branco (sem inclusão de cDNA na reação). Ensaio realizado no Chromo 4 (MJ Research) utilizando Platinum SYBR Green qPCR Supermix UDG (Invitrogen).

Fonte: (FERNANDES, 2012)

\subsection{HISTOLOGIA}

Após a morte, a pele dos animais foi coletada e passada por um processo de fixação em formol tamponado $10 \%$ de PBS por 24 horas, seguido de desidratação em álcool, diafanização em xilol e inclusão em parafina. Os cortes com espessura de $5 \mu \mathrm{m}$ foram realizados em micrótomo. A coloração foi feita por hematoxilina e eosina e a montagem das lâminas foi feita com lamínula e entelan. 


\subsection{ANÁLISE ESTATÍSTICA}

As significâncias entre as médias foram calculadas pelo ANOVA one-way, seguido pelo teste de Turkey (teste de múltiplas comparações), para $p<0.05$ pelo programa GraphPad Prism 5.0 (GraphPad Software, La Jolla, CA, Estados Unidos). 


\section{RESULTADOS}

\subsection{INFILTRAÇÃO DE CÉLULAS NO EXSUDATO PRODUZIDO PELO BIOGEL}

Biogel P-100 são esferas de poliacrilamida porosa. É uma substância inerte, não biodegradável e não imunogênica agindo assim como substância estranha que provoca uma inflamação no local de sua aplicação (STIFFEL et al., 1990). Essa solução foi utilizada em nosso laboratório como agente promotor da resposta inflamatória no desenvolvimento do processo seletivo para obtenção das linhagens AIRmax e AIRmin. No local de aplicação do Biogel, é formado um exsudato rico em células e proteínas que caracterizam o fenótipo de alta ou baixa resposta inflamatória dos animais AIRmax e AIRmin, respectivamente. Portanto, o nosso primeiro passo foi o de avaliar o perfil de células totais e caracterizar essas células presentes no exsudato produzido pela injeção de Biogel P-100 no dorso desses camundongos em períodos diferentes das 24 horas já bem estabelecida por outros trabalhos do nosso grupo. Os períodos analisados foram 48 horas e 30 dias e os resultados são mostrados a seguir.

Foi observado que para o número de células totais, os animais AIRmax tem valores consideravelmente maiores do que os animais AIRmin nos dois períodos avaliados. Estes últimos por sua vez, mostraram um aumento no número de células aos 30 dias quando comparados ao período de 48 horas, embora não tenha sido detectada diferença estatística (Figura 3A). Na contagem diferencial de leucócitos observamos que os AIRmax têm maior porcentagem de neutrófilos que os AIRmin em ambos os períodos, sendo que o número absoluto de células diminui aos 30 dias onde observamos uma maior porcentagem de monócitos (Figuras 3C e 3D). Na linhagem AIRmin há uma maior porcentagem de células neutrofílicas em 48 horas, um perfil que também muda no $30^{\circ}$ dia quando os monócitos passam a ser o tipo celular mais abundante (Figuras 3C e 3D). Nesses animais observamos ainda uma pequena porcentagem de eosinófilos nos dois períodos, que foi maior que nos AIRmax (Figura 3B). Quanto ao número absoluto de células, observamos que os animais AIRmax tem mais neutrófilos, monócitos e eosinófilos em ambos os períodos (Tabela 1). 
Figura 3 - Número de células extravasadas ao sitio de aplicação de Biogel nos animais AIRmax e AIRmin.

A)

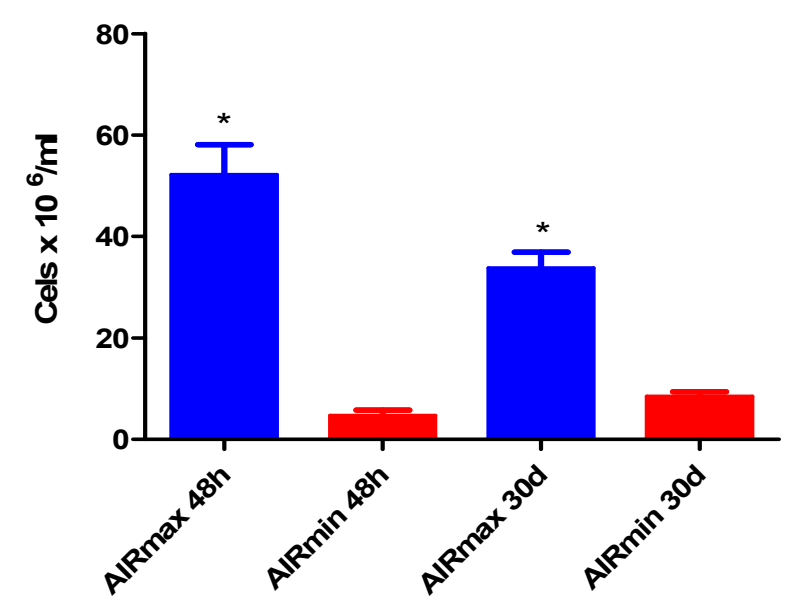

C)

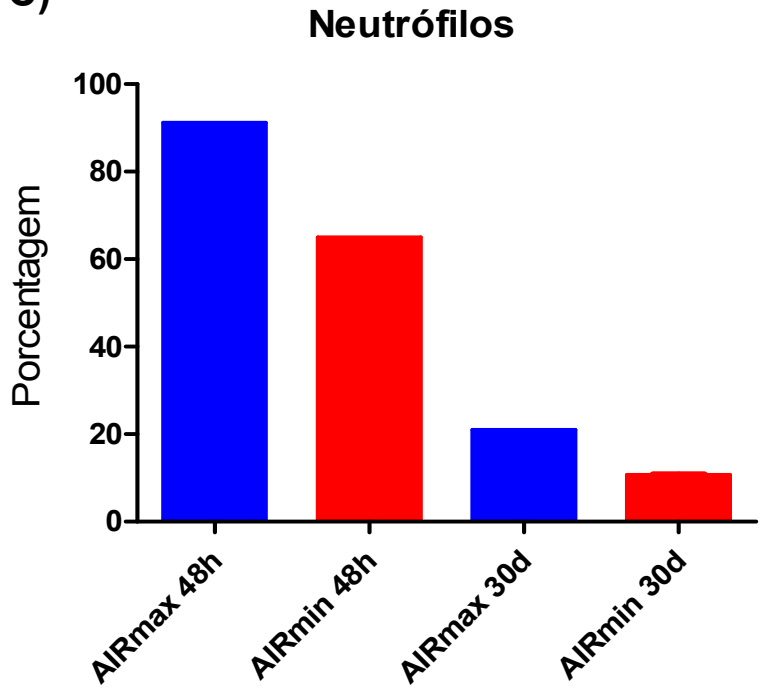

B)

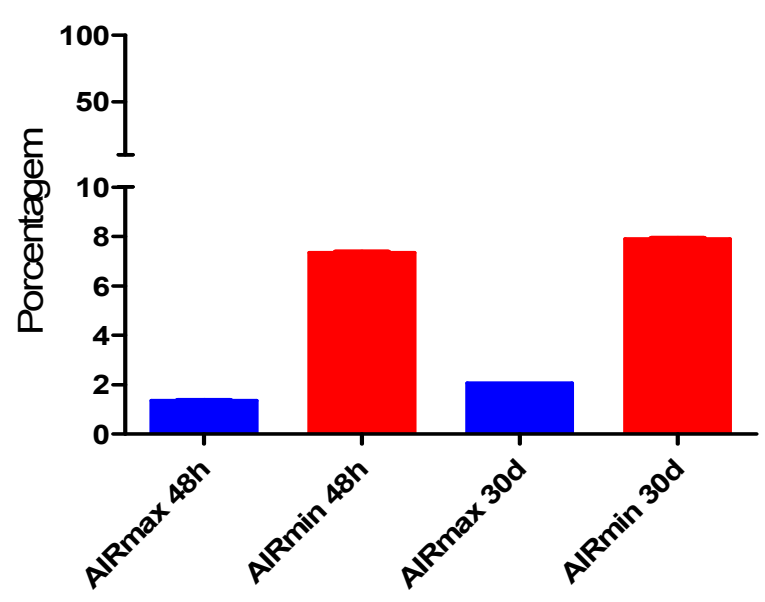

D)

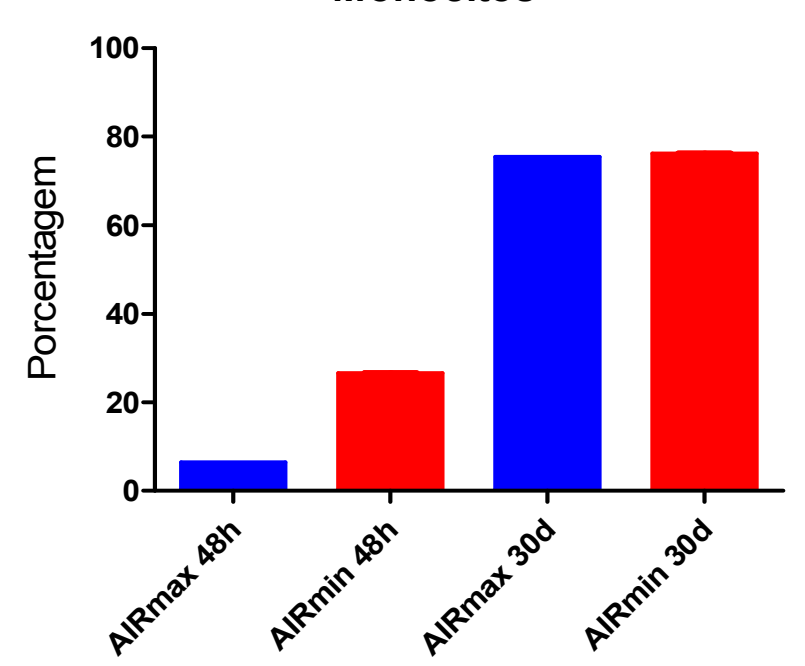

(a) Contagem de células totais. (b, c e d) Contagem diferencial das células extravasadas para o exsudato apresentadas em porcentagem ( $n=4$ camundongos por grupo). Os dados são apresentados como médias \pm erro padrão da média e análise estatística por ANOVA. * $p<0.05$ - entre camundongos AIRmax e AIRmin.

Fonte: (FERNANDES, 2012) 
Tabela 1 - Migração de células no exsudato inflamatório dos animais AIRmax e AIRmin

\begin{tabular}{lcc}
\hline Camundongos & $\begin{array}{c}\text { Infiltração de Neutrófilos } \pm \text { EP } \\
\left(\times 10^{5} / \mathrm{ml}\right) \underline{48 \mathrm{~h}}\end{array}$ & $\begin{array}{c}\text { Infiltração de Neutrófilos } \pm \text { EP } \\
\left(\times 10^{5} / \mathrm{ml}\right) \underline{30} \text { dias }\end{array}$ \\
\hline AIRmax & $477,59 \pm 113,22$ & $75,48 \pm 23,81$ \\
AIRmin & $30,27 \pm 13,09$ & $11,84 \pm 8,17$ \\
\hline & Infiltração de Monócitos \pm EP & Infiltração Monócitos \pm EP \\
& $\left(\times 10^{5} / \mathrm{ml}\right) \underline{48 \mathrm{~h}}$ & $\left(\times 10^{5} / \mathrm{ml}\right) \underline{30 \text { dias }}$ \\
\hline AIRmax & $32,45 \pm 5,76$ & $250,57 \pm 37,11$ \\
AIRmin & $13,56 \pm 7,31$ & $60,77 \pm 5,92$ \\
\hline & Infiltração de Eosinófilos \pm EP & Infiltração de Eosinófilos \pm EP \\
& $\left(\times 10^{5} / \mathrm{ml}\right) \underline{48 \mathrm{~h}}$ & $\left(\times 10^{5} / \mathrm{ml}\right) \underline{30 \text { dias }}$ \\
\hline AIRmax & $6,18 \pm 2,63$ & $6,88 \pm 1,30$ \\
AIRmin & $2,41 \pm 0,62$ & $7,62 \pm 3,67$
\end{tabular}

Número absoluto de células migradas sítio de aplicação de Biogel P-100 nos animais AIRmax e AIRmin, após 48 horas e 30 dias da aplicação de Biogel, mostradas como médias \pm erro padrão da média ( $\mathrm{n}=4$ camundongos por grupo)

Fonte: (FERNANDES, 2012)

\subsection{QUANTIFICAÇÃO DE CITOCINAS NO EXSUDATO}

As partículas de Biogel produzem uma inflamação no local de sua aplicação. Junto com as células extravasadas para esse local, extravasam também proteínas que muitas vezes podem ser detectadas por imunoensaios como o Enzyme Linked Immunosorbent Assay (ELISA). No presente trabalho nós utilizamos esse método para detectarmos a presença de citocinas e quimiocinas inflamatórias no exsudato dos animais AIRmax e AIRmin formado pelo Biogel após os períodos de 48 horas e 30 dias.

As citocinas IL-6, IL-1 $\beta$, TNF- $\alpha$ e CCL2 (MCP-1) foram encontradas no exsudato dos animais AIRmax em altas concentrações no período de 48 horas sendo que esses valores foram significativamente maiores do que nos camundongos AIRmin neste mesmo período (Figura 4). Aos 30 dias os níveis dessas citocinas são quase indetectáveis em ambas as linhagens (Figura 4). Nos animais controles injetados com salina não foram detectados níveis de IL-6, IL-1 $\beta$, TNF- $\alpha$ no exsudato. Já para a CCL2, os mesmos animais controles mostraram níveis detectáveis dessa 
quimiocina em 48 horas, sendo que essa expressão nos AIRmax foi significativamente maior do que nos AIRmin (Figura 4D).

Figura 4 - Níveis das citocinas IL-1 $\beta$, TNF- $\alpha$, IL-6 e CCL2 no exsudato

\section{IL-1 $\beta$}
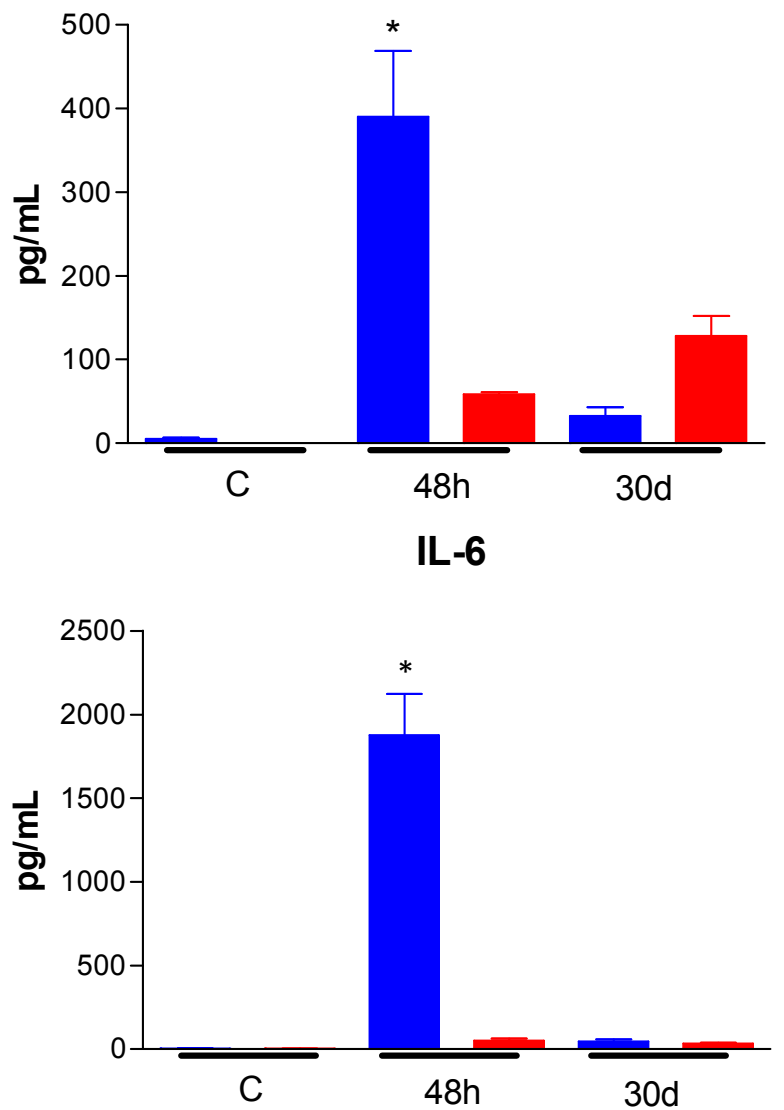

TNF- $\alpha$
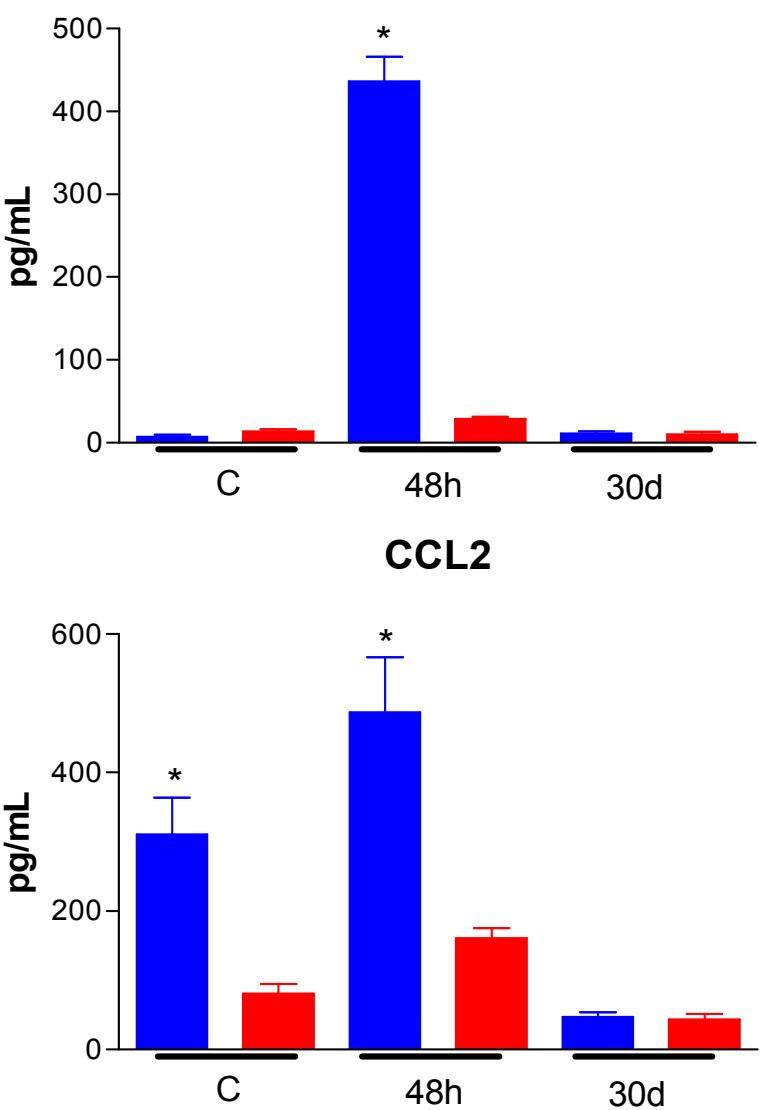

Níveis das citocinas IL-1 $\beta$, TNF- $\alpha$, IL-6 e CCL2 presentes no exsudato de animais AIRmax e AIRmin machos e fêmeas após estímulo inflamatório com Biogel P-100 no dorso subcutâneo desses camundongos. Dosagem realizada pelo método de ELISA em placas de microtitulação de poliestireno. Os dados são expressos como médias \pm erro padrão da média e análise estatística por ANOVA. * $p<0.05$ - entre camundongos AIRmax ( $\square)$ e AIRmin ( $\square)(n=4$ camundongos por grupo). Fonte: (FERNANDES, 2012)

\subsection{DETECÇÃO DE CITOCINAS INFLAMATÓRIAS NO SORO}

O ensaio com o aparelho Bioplex foi realizado para detectar a presença de citocinas inflamatórias no soro de animais submetidos à aplicação de Biogel por 48 horas ou 30 dias. Esse método funciona como uma espécie de array no qual em um mesmo ensaio, foi possível analisar a presença de 7 citocinas diferentes (IL-1 $1 \beta$, 
TNF- $\alpha$, IL-6, CXCL2, GM-CSF, IL-17, IL-10). A detecção de TGF- $\beta$ foi realizada em um ensaio independente.

\subsubsection{Níveis de IL-17 e IL-10 no soro}

As citocinas IL-17 e IL-10 foram encontradas no soro dos animais AIRmax estimulados com Biogel por 30 dias, em concentrações significativamente maiores do que nos AlRmin estimulados pelo mesmo período (Figura 5). Após 48 horas da estimulação com Biogel e nos animais controles, essas citocinas não apresentaram concentrações significativas em ambas as linhagens.

Figura 5 - Níveis de IL-17 e IL-10 no soro

\section{IL-17}

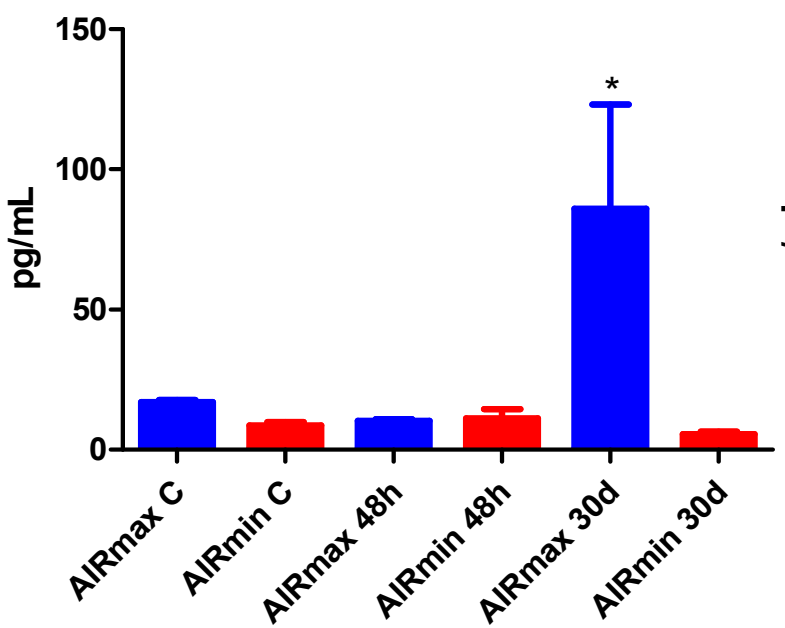

IL-10

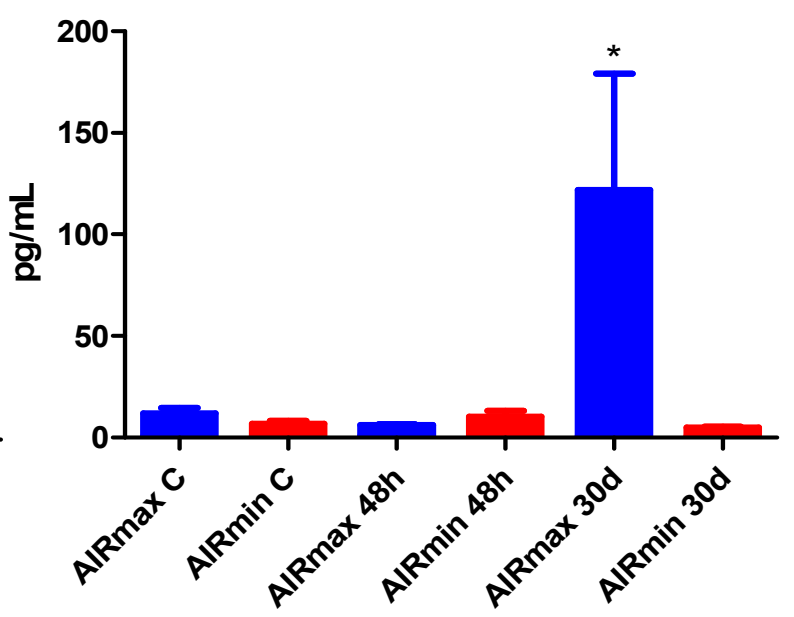

Níveis de IL-17 e IL-10 no soro de animais da linhagem AIR após 48 horas ou 30 dias da injeção de Biogel no dorso subcutâneo. Dosagem feita no aparelho Bioplex pelo kit Milliplex®map. Os dados são expressos como médias \pm erro padrão da média e análise estatística por ANOVA. * $p<0.05$ - entre camundongos AIRmax e AIRmin ( $\mathrm{n}=4$ camundongos por grupo).

Fonte: (FERNANDES, 2012)

\subsubsection{Níveis de outras citocinas no soro}

Os níveis das citocinas IL-1 $\beta$, TNF- $\alpha$ e do GM-CSF foram muito baixos e não significativos, sendo que em alguns camundongos esses níveis foram indetectáveis. A IL-6 só foi significativamente maior nos animais AIRmax com 30 dias de estímulo 
em relação aos AIRmin, enquanto os níveis de CXCL2 foram estatisticamente maiores na linhagem AIRmin após 48 horas (Figura 6).

A citocina anti-inflamatória TGF- $\beta$ apareceu no soro em níveis elevados em ambas as linhagens e em todos os períodos, mas a diferença entre elas só foi registrada nos animais AIRmax basais quando comparados aos animais AIRmin basais e aos seus experimentais (Figura 6).

Apesar de algumas das citocinas citadas acima apresentarem diferenças estatísticas em alguns períodos entre as linhagens, esses resultados não foram relevantes e não correlacionam com outros fenótipos apresentados neste trabalho.

Figura 6 - Níveis de IL-6, CXCL2 e TGF- $\beta$ no soro

IL-6

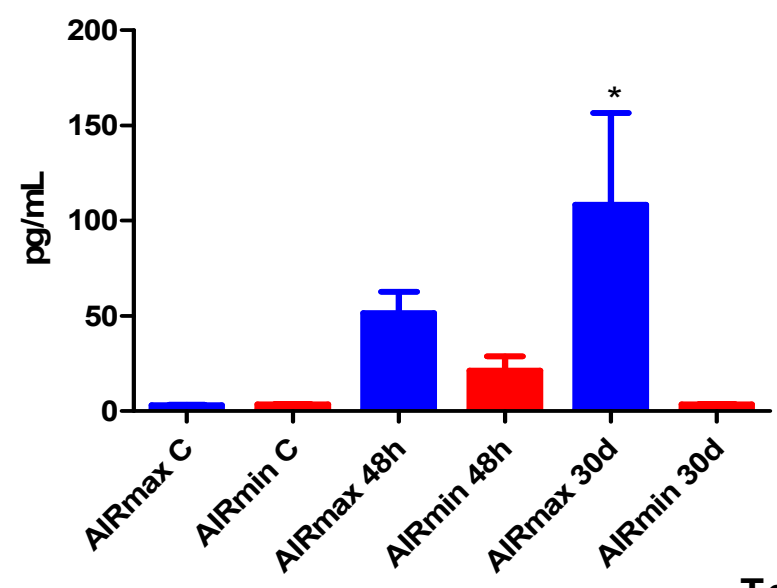

Cxc12

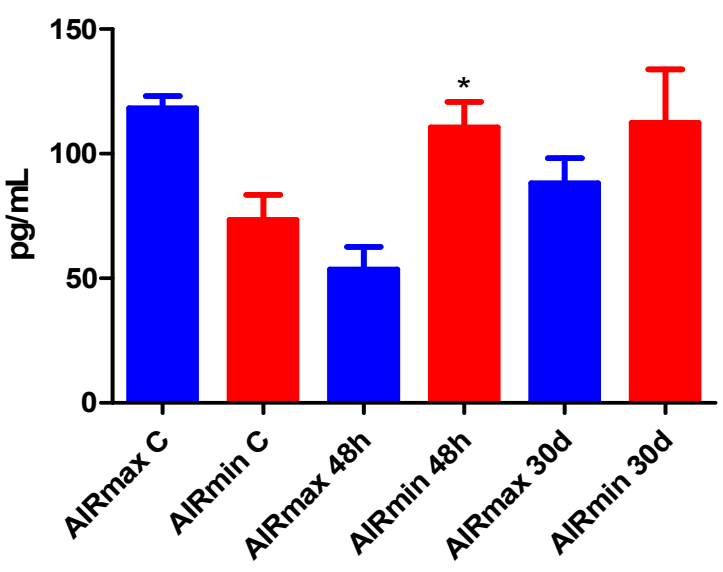

Tgfb

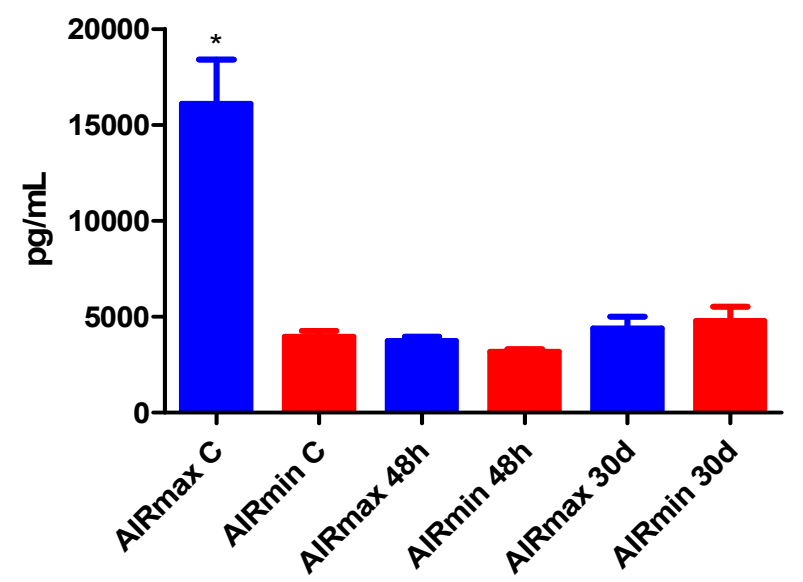

Níveis de IL-6, CXCL2 e TGF- $\beta$ no soro de animais da linhagem AIR após 48 horas ou 30 dias da injeção de Biogel no dorso subcutâneo desses camundongos. Dosagem feita no aparelho Bioplex pelo kit Milliplex®map da Millipore. Os dados são expressos como médias \pm erro padrão da média e análise estatística por ANOVA. * $p<0.05$ - entre camundongos AIRmax e AIRmin ( $n=4$ camundongos por grupo).

Fonte: (FERNANDES, 2012) 


\subsection{ESTUDO DA EXPRESSÃO GÊNICA GLOBAL}

A análise da expressão gênica global teve como objetivo identificar os genes ativados e reprimidos durante a inflamação nas linhagens AIRmax e AIRmin e os genes diferentemente expressos entre elas. Como os polimorfismos podem ocorrer em regiões que controlam expressão gênica nós realizamos o transcriptoma do tecido subcutâneo extraído 48 horas depois da injeção de Biogel no dorso das linhagens e de animais controle para tentar correlacionar os genes diferentemente expressos com os QTLs reguladores da inflamação previamente mapeados. Esses genes foram detectados utilizando o programa SAM (análise de significância de microarray) para uma taxa de falsa detecção $(F D R)<5 \%$. Além disso, nós só consideramos os genes que tiveram pelo menos 2 vezes de diferença de expressão.

Em uma análise inicial, foi observada a modulação de genes em ambas as linhagens sendo que os camundongos AIRmax apresentaram 488 genes ativados e 209 reprimidos em relação aos controles, enquanto os camundongos AIRmin tiveram 108 genes ativados e apenas 1 gene reprimido (Tabela 3).

Entre os animais controles somente 39 genes se expressaram diferencialmente entre as linhagens, sendo que 29 desses genes mostraram maior expressão na linhagem AIRmax e 10 foram mais expressos na linhagem AIRmin (Tabela 4). Depois de submetidos ao protocolo de aplicação do Biogel, foi observado que 271 genes se expressaram diferencialmente entre as linhagens, sendo que 208 desses genes, foram mais expressos nos animais AIRmax e 63 genes foram mais expressos nos animais AIRmin (Tabela 5).

Tabela 2 - Número de genes ativados e reprimidos nas linhagens AIR

\begin{tabular}{lll}
\hline & Ativados & Reprimidos \\
\hline AlRmax & 488 & 209 \\
AIRmin & 108 & 01 \\
\hline
\end{tabular}

Número de genes ativados e reprimidos no tecido subcutâneo de animais das linhagens AIR após estímulo com Biogel por 48 horas. O valor calculado de genes ativados e reprimidos foi realizado utilizando programa de análise de significância de microarray (SAM) com FDR (False Discovery Rate) $<5 \%$, considerando uma diferença mínima de 2 vezes para os genes diferentemente expressos.

Fonte: (FERNANDES, 2012) 
Tabela 3 - Número de genes diferentemente expressos entre animais AIRmax e AIRmin controles.

\begin{tabular}{cc}
\hline Controles & Genes mais expressos \\
\hline AIRmax / AIRmin & 29 \\
AIRmin / AIRmax & 10 \\
\hline
\end{tabular}

Número de genes diferentemente expressos no tecido subcutâneo de animais AIRmax e AIRmin controles. A diferença de expressão foi calculada utilizando programa de análise de significância de microarray (SAM) com FDR (False Discovery Rate) $<5 \%$, considerando uma diferença mínima de 2 vezes para os genes diferentemente expressos.

Fonte: (FERNANDES, 2012)

Tabela 4 - Número de genes diferentemente expressos nos animais AlRmax e AIRmin após aplicação de Biogel.

\begin{tabular}{cc}
\hline Experimentais & Genes mais expressos \\
\hline AIRmax / AIRmin & 208 \\
\hline AIRmin / AIRmax & 63 \\
\hline
\end{tabular}

Número de genes diferentemente expressos no tecido subcutâneo de animais AIRmax e AIRmin após 48 horas da aplicação de Biogel. A diferença de expressão foi calculada utilizando programa de análise de significância de microarray (SAM) com FDR (False Discovery Rate) $<5 \%$, considerando uma diferença mínima de 2 vezes para os genes diferentemente expressos.

Fonte: (FERNANDES, 2012)

Em outra análise, nós utilizamos o programa EASE para avaliação dos genes diferentemente expressos e agrupados em categorias funcionais. Esse programa é capaz de separar os genes diferentemente expressos de acordo com a categoria funcional, em temas biológicos, como resposta inflamatória, resposta imune, transdução de sinal, entre outros.

Nas figuras seguintes, estão representados os genes ativados nos animais AIRmax e AIRmin experimentais, agrupados na categoria de Transdução de sinal, Reposta Imune e Resposta Inflamatória. 
Figura 7 - Genes ativados no tecido das linhagens AIRmax e AIRmin

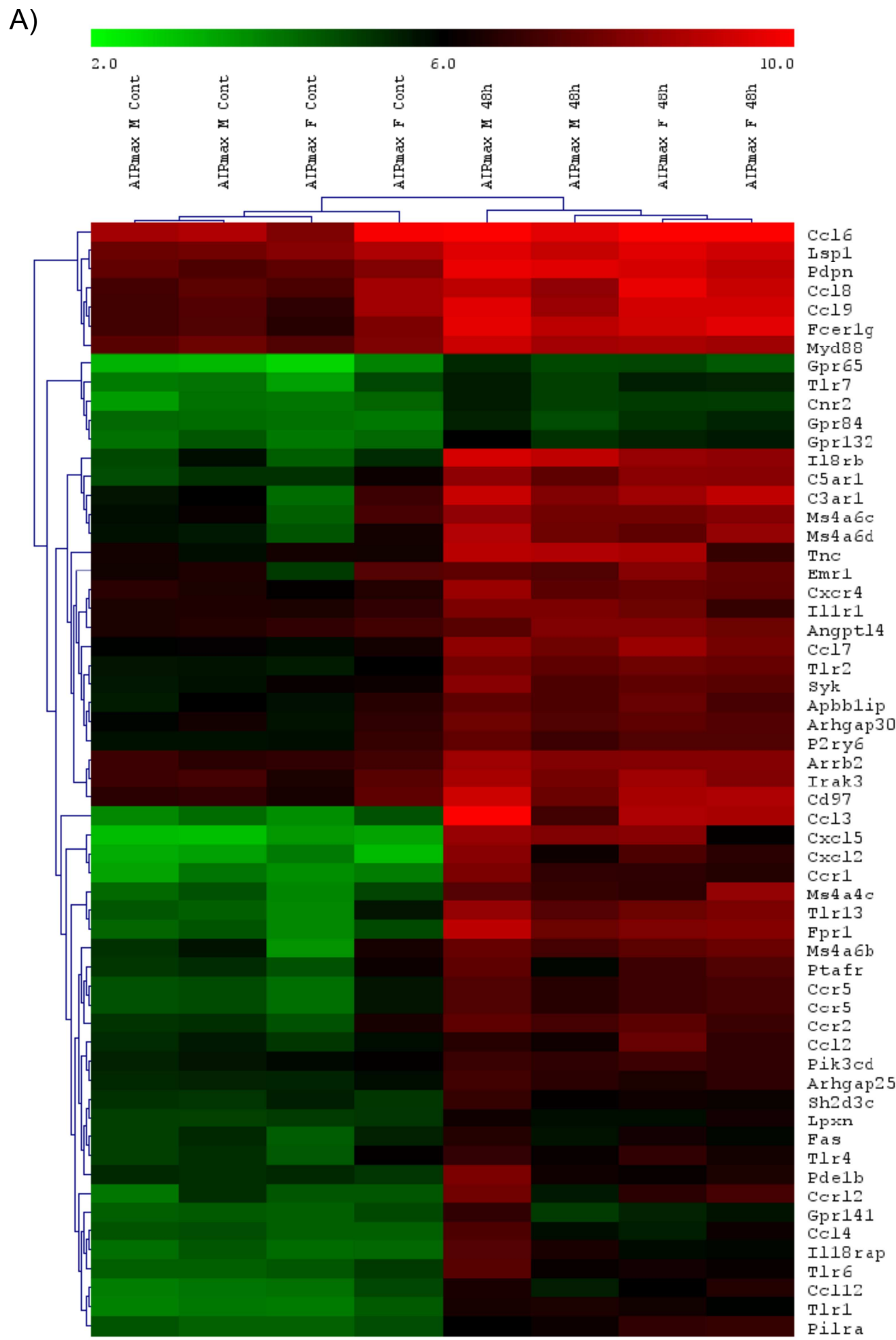


B)

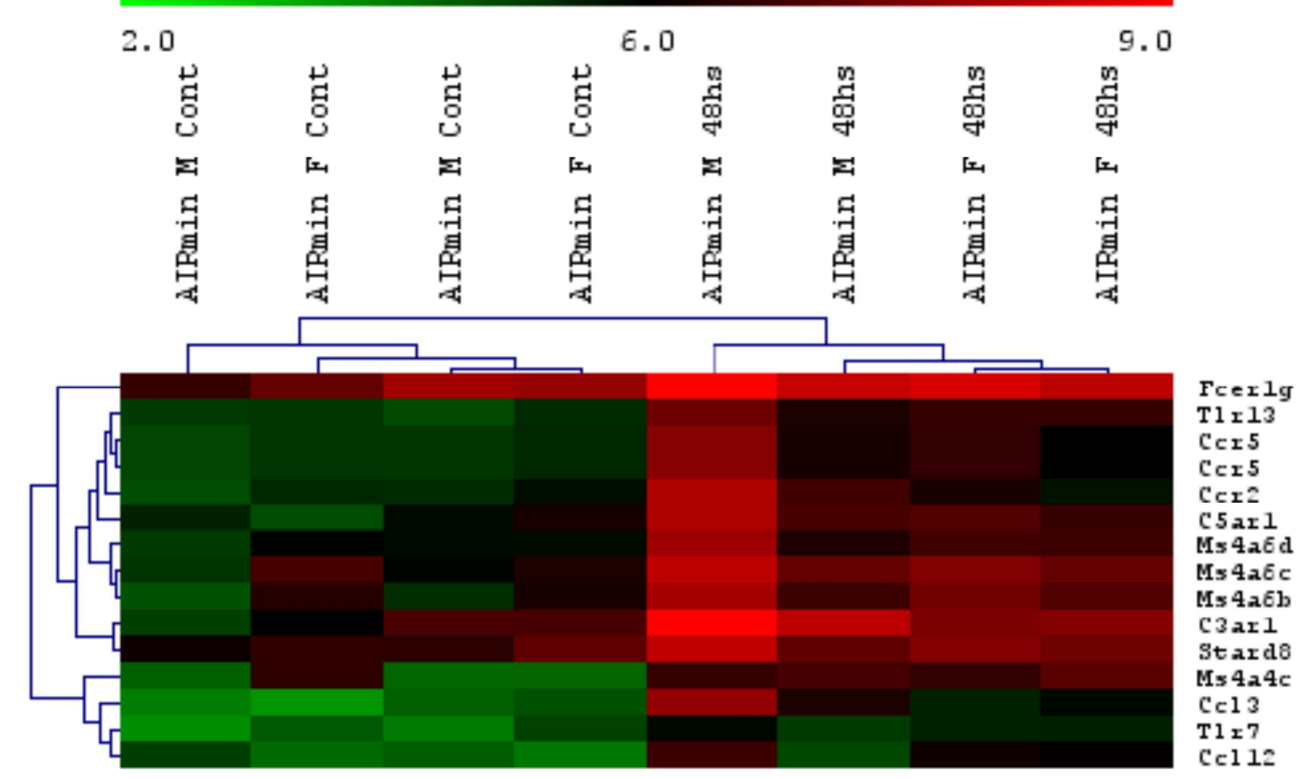

Genes ativados na linhagem AIRmax (A) e AIRmin (B) e agrupados na categoria de transdução de sinal, após 48 horas da aplicação de Biogel. A diferença de expressão foi calculada utilizando programa de análise de significância de microarray (SAM) para uma taxa de falsa detecção (FDR) $<5 \%$ considerando uma diferença mínima de 2 vezes para os genes diferentemente expressos.

Fonte: (FERNANDES, 2012) 
Figura 8 - Genes ativados no tecido dos camundongos AIRmax e AIRmin

A)

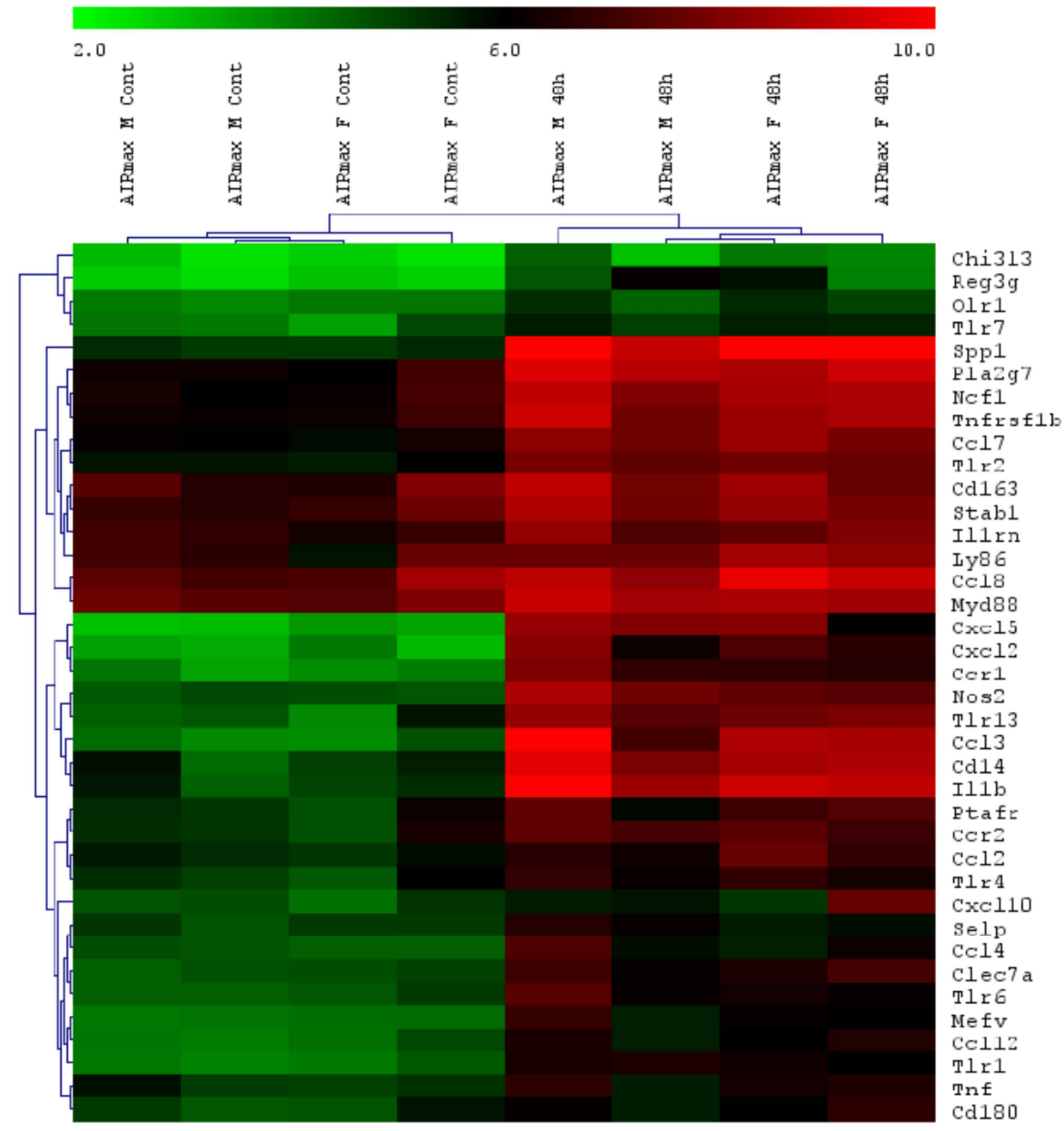

B)

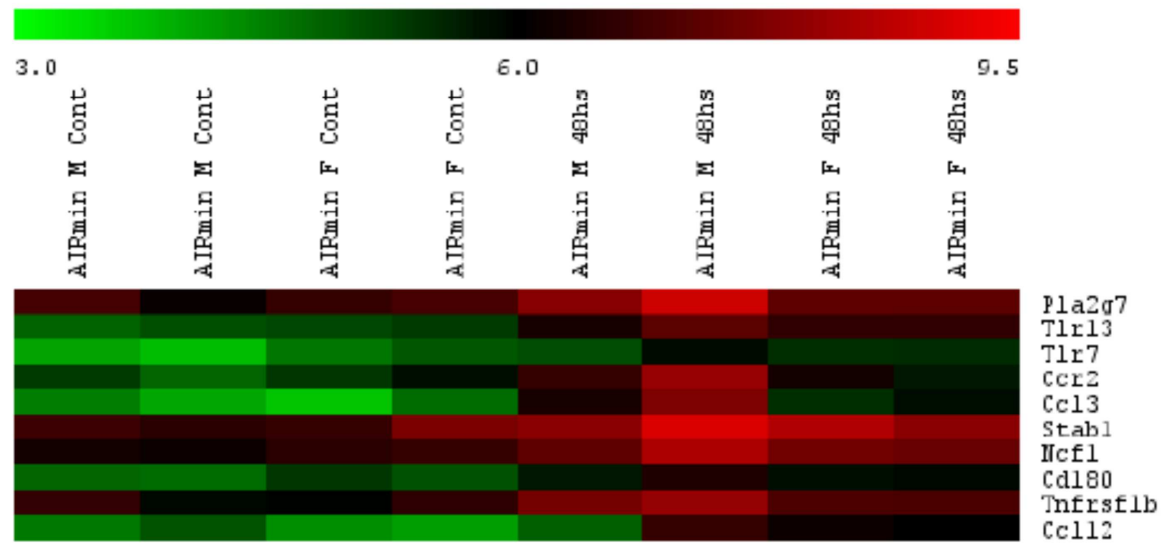

Genes ativados nas linhagens AIRmax (A) e AIRmin (B) e agrupados na categoria de resposta inflamatória, após 48 horas da aplicação de Biogel. A diferença de expressão foi calculada utilizando programa de análise de significância de microarray (SAM) para uma taxa de falsa detecção (FDR) $<5 \%$ considerando uma diferença mínima de 2 vezes para os genes diferentemente expressos.

Fonte: (FERNANDES, 2012) 
Figura 9 - Genes ativados no tecido dos camundongos AIRmax

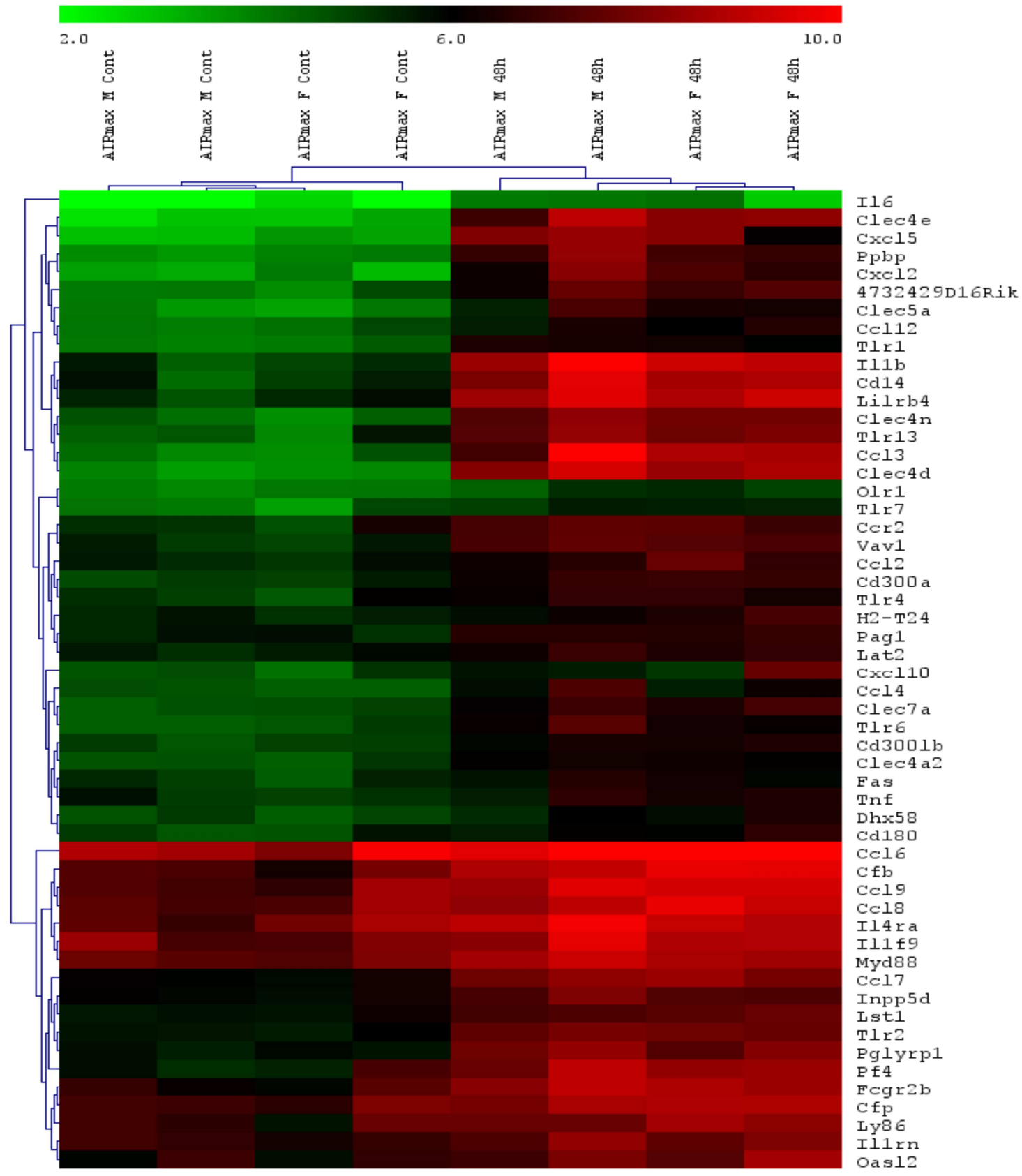

Genes ativados na linhagem AIRmax e agrupados na categoria de resposta imune, após 48 horas da aplicação de Biogel. A diferença de expressão foi calculada utilizando programa de análise de significância de microarray (SAM) para uma taxa de falsa detecção (FDR) $<5 \%$ considerando uma diferença mínima de 2 vezes para os genes diferentemente expressos.

Fonte: (FERNANDES, 2012)

A seguir, as figuras mostram os genes reprimidos nos animais AIRmax experimentais e agrupados nas categorias de Contração Muscular e Organização do Citoesqueleto. 
Figura 10 - Genes reprimidos no tecido dos camundongos AIRmax

A)

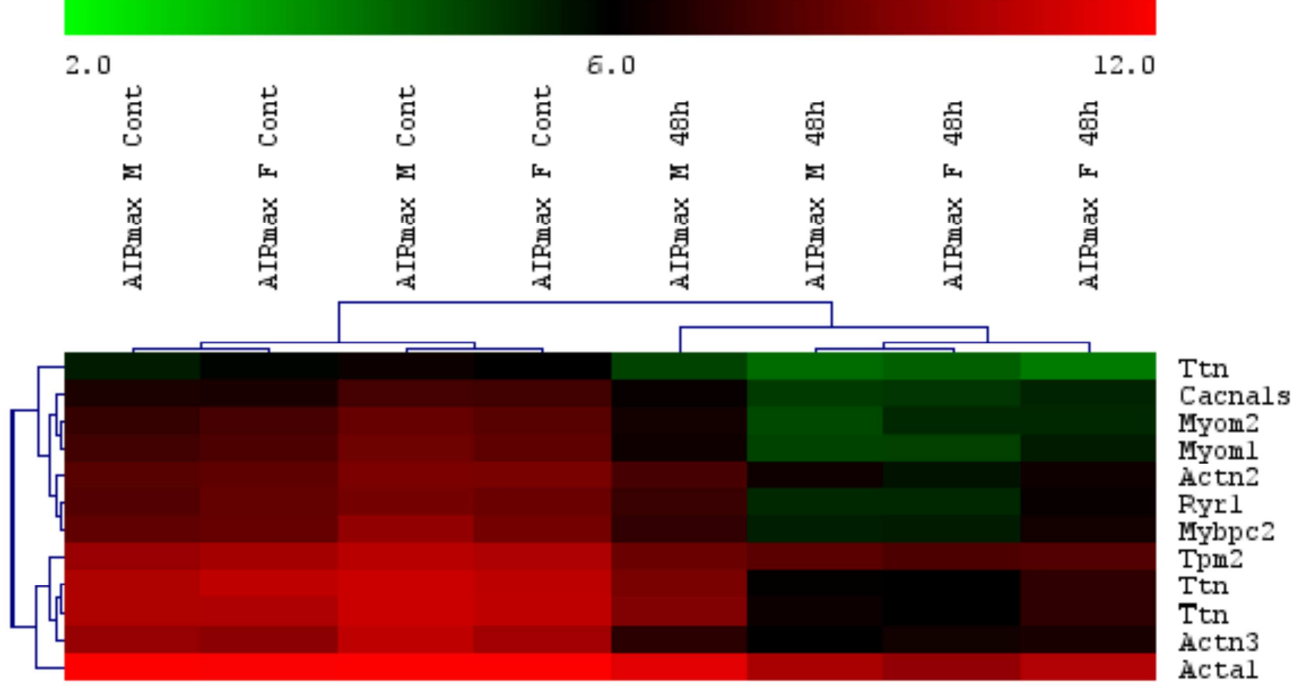

B)

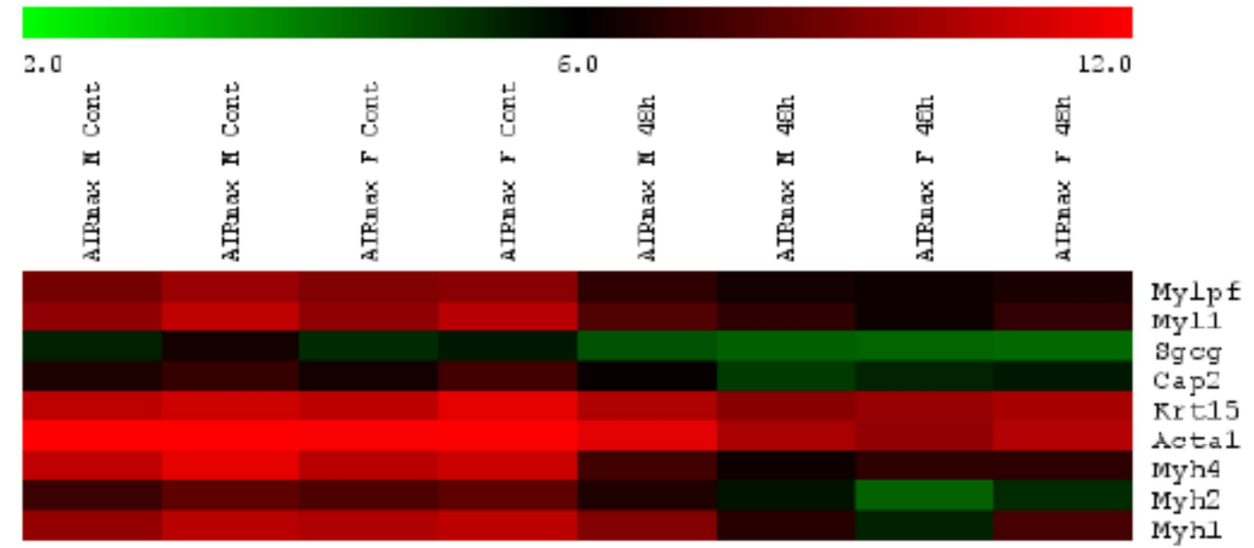

Genes reprimidos na linhagem AIRmax e agrupados na categoria de contração muscular $(A)$ e organização do citoesqueleto (B), após 48 horas da aplicação de Biogel. A diferença de expressão foi calculada utilizando programa de análise de significância de microarray (SAM) para uma taxa de falsa detecção (FDR) $<5 \%$ considerando uma diferença mínima de 2 vezes para os genes diferentemente expressos.

Fonte: (FERNANDES, 2012)

As figuras seguintes, representam os genes diferentemente expressos entre as linhagens AIRmax e AIRmin experimentais. Os genes mais expressos na linhagem AIRmax foram separados nas categorias de resposta imune, reposta inflamatória, transdução de sinal e adesão celular. Os genes agrupados e envolvidos com transporte, apoptose e processo catabólico do colágeno também estão representados. 
Figura 11 - Genes mais expressos na linhagem AIRmax em relação a linhagem AIRmin

A)

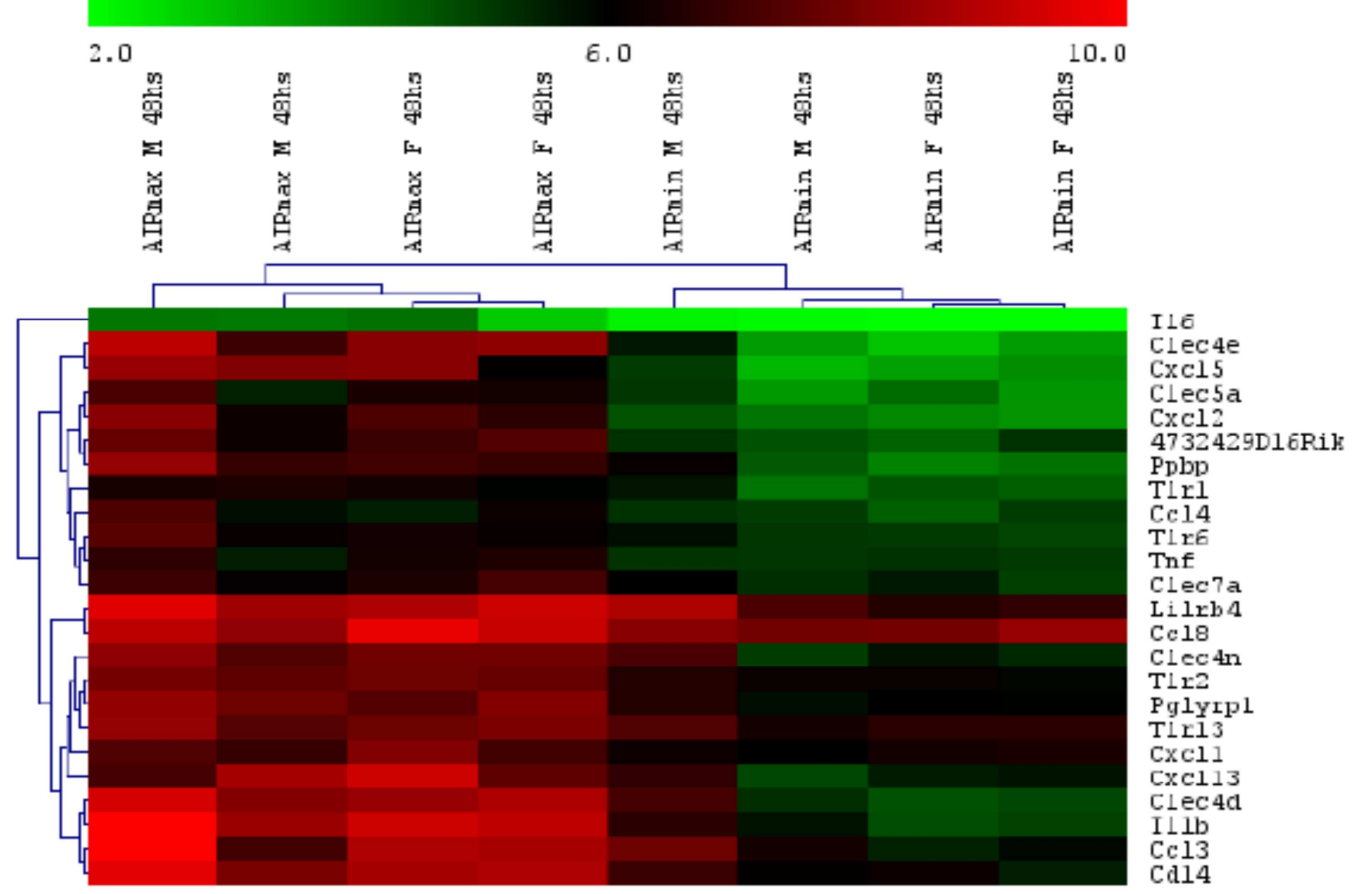

B)

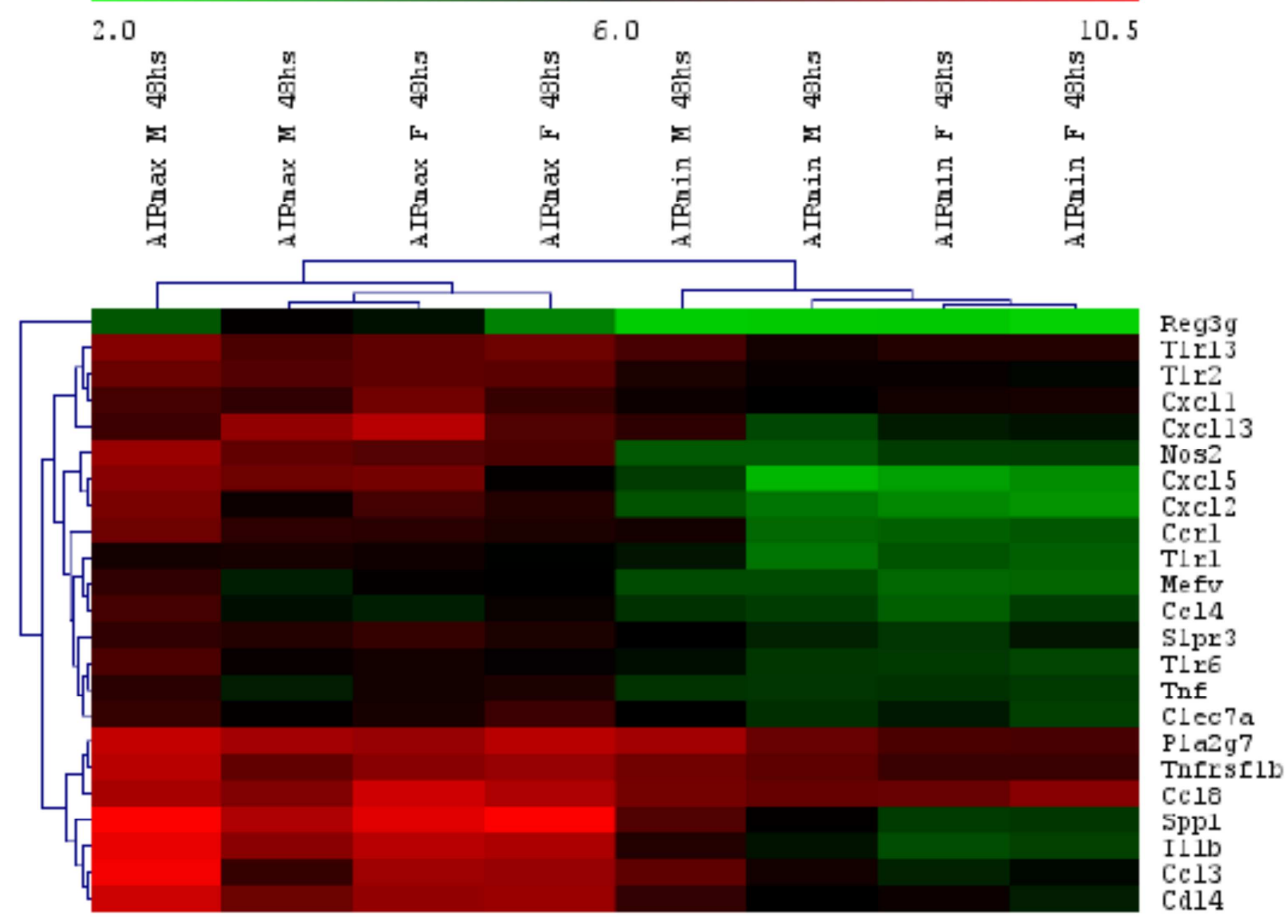


C)

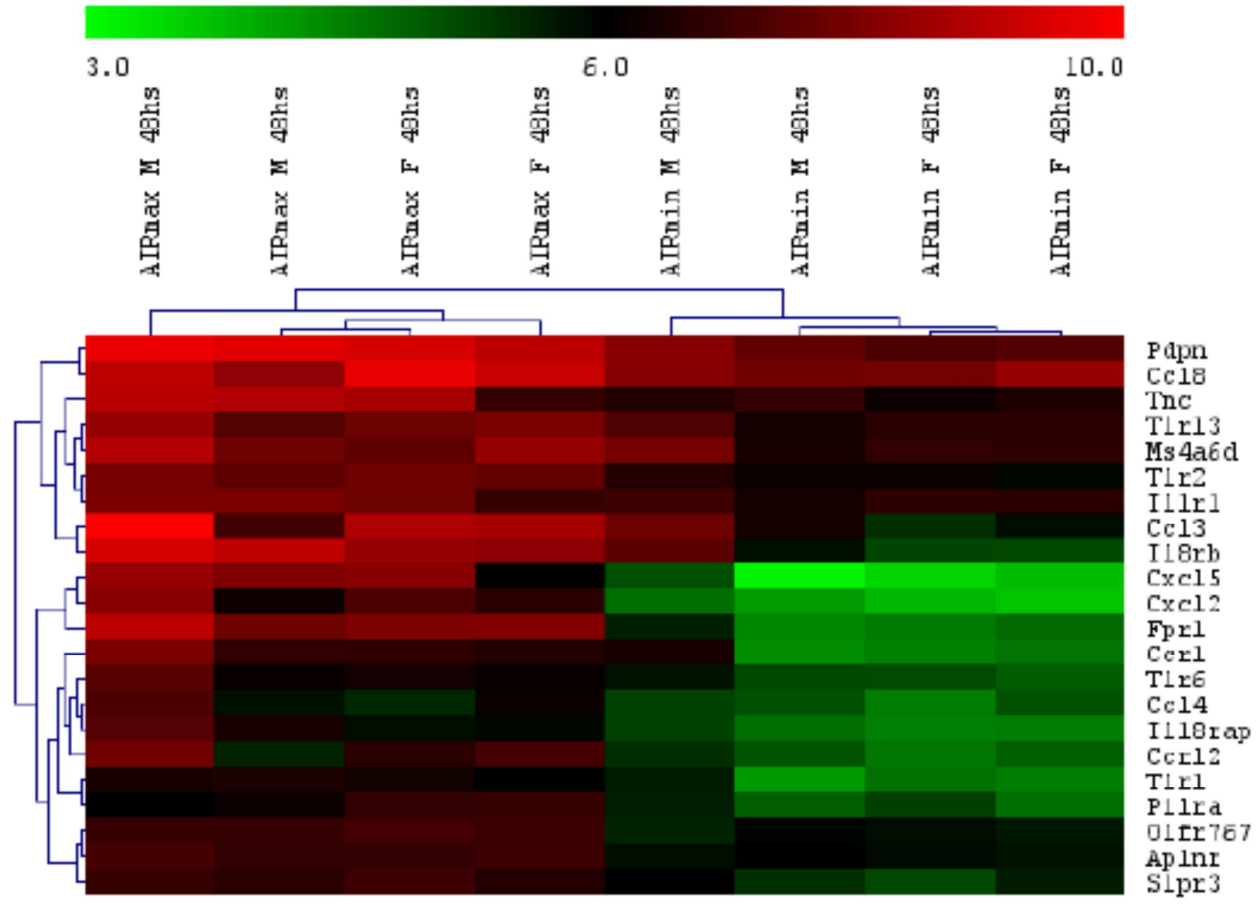

D)

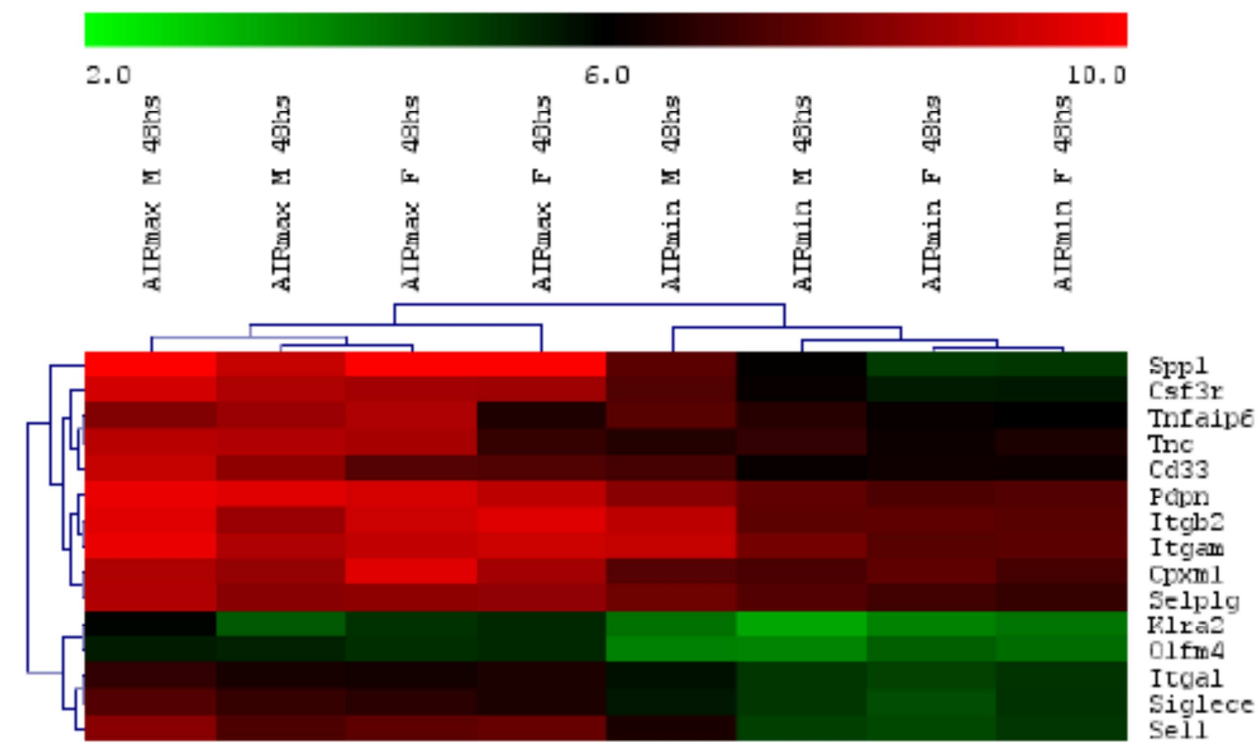

Genes mais expressos na linhagem AIRmax em relação a linhagem AIRmin, sobre-representados na categoria de resposta imune $(A)$, resposta inflamatória $(B)$, transdução de sinal $(C)$ e adesão celular (D), após 48 horas da aplicação de Biogel. A diferença de expressão foi calculada utilizando programa de análise de significância de microarray (SAM) para uma taxa de falsa detecção (FDR) $<5 \%$ considerando uma diferença mínima de 2 vezes para os genes diferentemente expressos.

Fonte: (FERNANDES, 2012) 
Figura 12 - Genes mais expressos na linhagem AIRmax em relação a linhagem AIRmin

A)
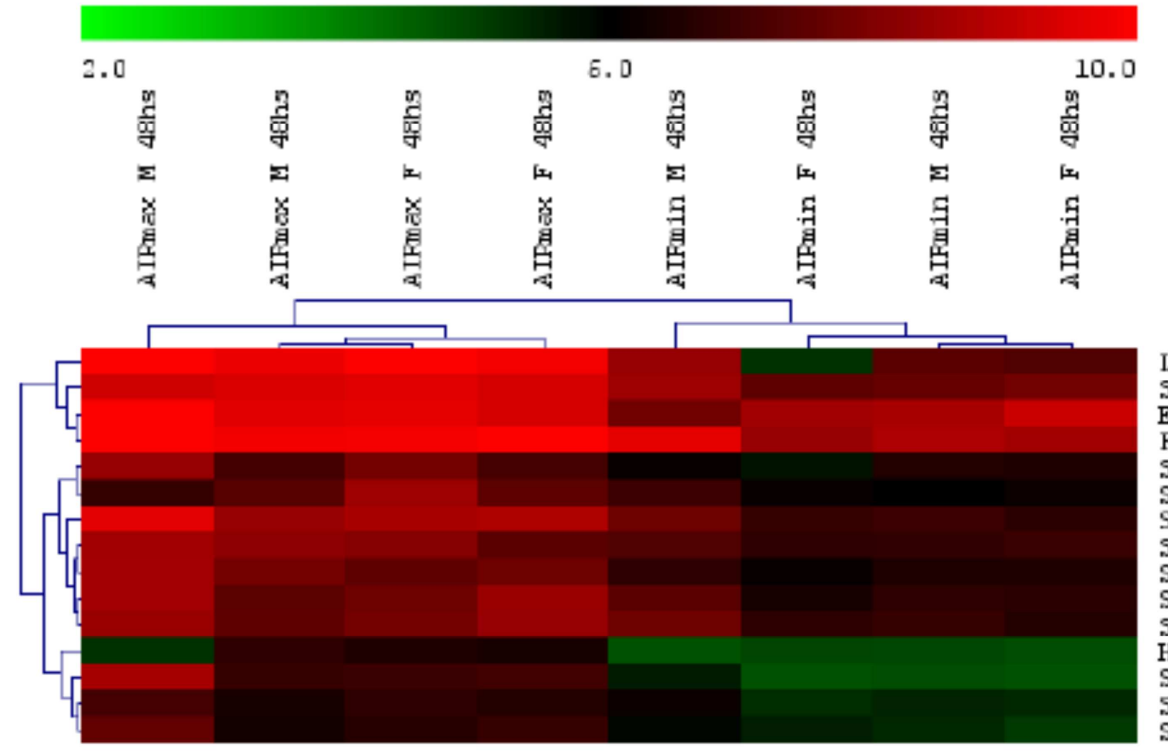

L.cn2

steap 4

Exo11

Fxyd 5

slc 7 a11

(c)

5lc39al4

Sor11

Slc15a3

slc11al

Hipx

$\operatorname{sic} 2 a_{3}$

5IXn.5

$\operatorname{sic} 2 a 6$

B)

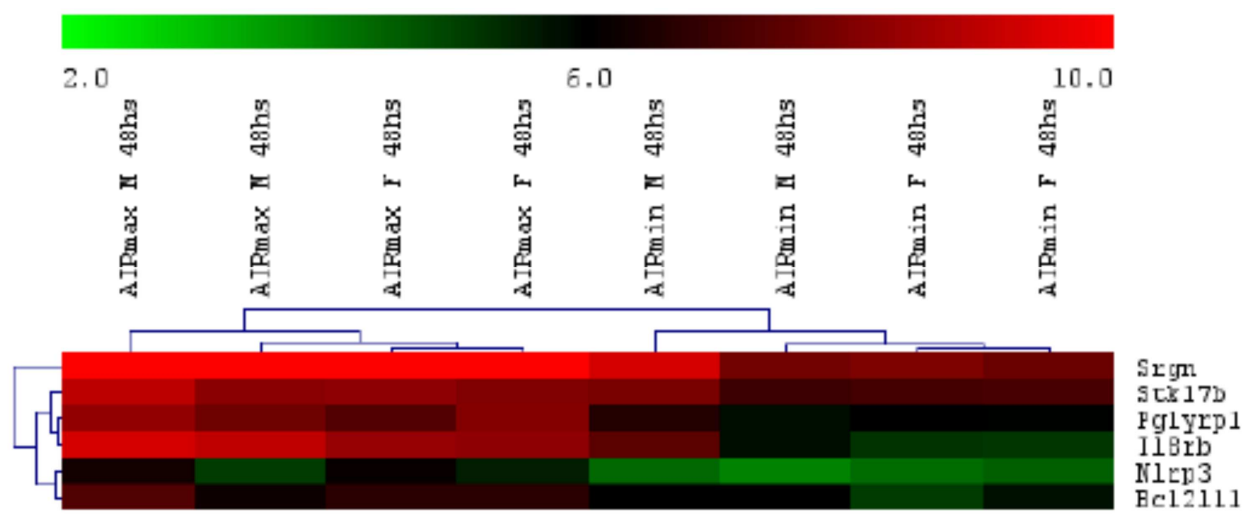

C)

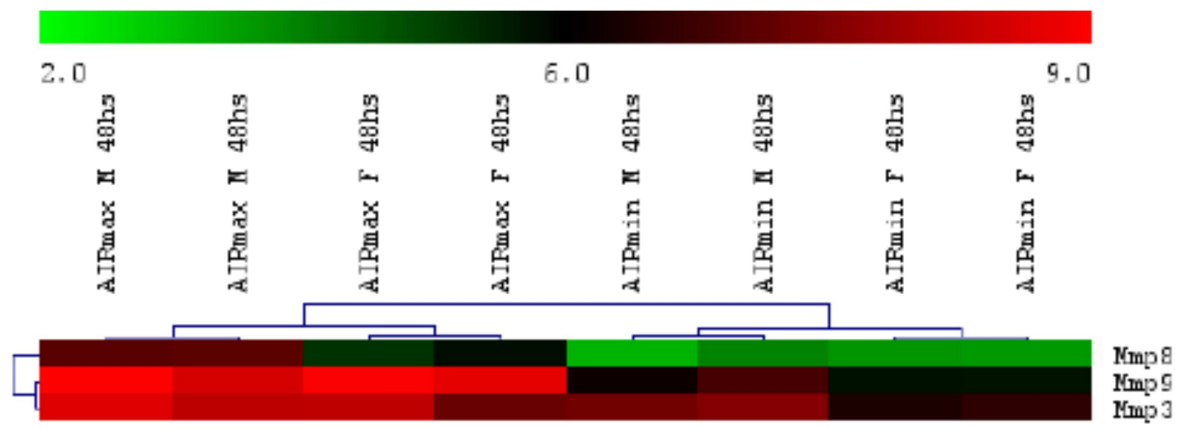

Genes mais expressos na linhagem AIRmax em relação a linhagem AIRmin e sobre-representados na categoria de transporte $(A)$, apoptose $(B)$ e processo catabólico do colágeno $(C)$ após 48 horas da aplicação de Biogel. A diferença de expressão foi calculada utilizando programa de análise de significância de microarray (SAM) para uma taxa de falsa detecção (FDR) $<5 \%$ considerando uma diferença mínima de 2 vezes para os genes diferentemente expressos.

Fonte: (FERNANDES, 2012) 
Os genes mais expressos na linhagem AIRmin foram separados nas categorias de Resposta Imune, Reposta Inflamatória e Transdução de Sinal. A seguir é mostrada somente a categoria de resposta imune.

Figura 13 - Genes mais expressos na linhagem AIRmin em relação a linhagem AIRmax

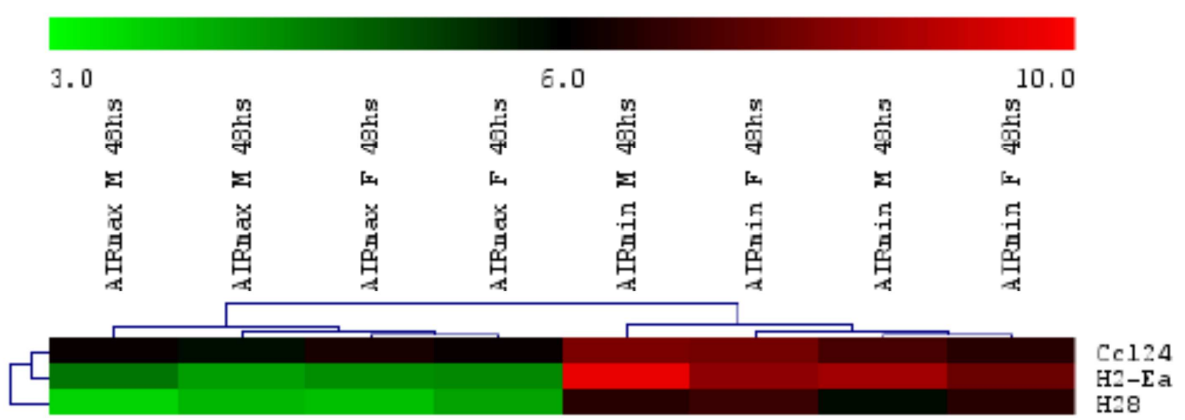

Genes mais expressos na linhagem AIRmin em relação a linhagem AIRmax e sobre-representados na categoria de resposta imune, após 48 horas da aplicação de Biogel. A diferença de expressão foi calculada utilizando programa de análise de significância de microarray (SAM) para uma taxa de falsa detecção (FDR) $<5 \%$ considerando uma diferença mínima de 2 vezes para os genes diferentemente expressos.

Fonte: (FERNANDES, 2012)

Quando separados por cromossomos, um agrupamento de genes mais expressos nos animais AIRmax foi observado principalmente nos cromossomos 5 e 7, locais onde os loci Irm2 e Irm1 foram mapeados, respectivamente (Figura 14A e B).

Figura 14 - Genes mais expressos na linhagem AIRmax em relação a linhagem AIRmin

A)

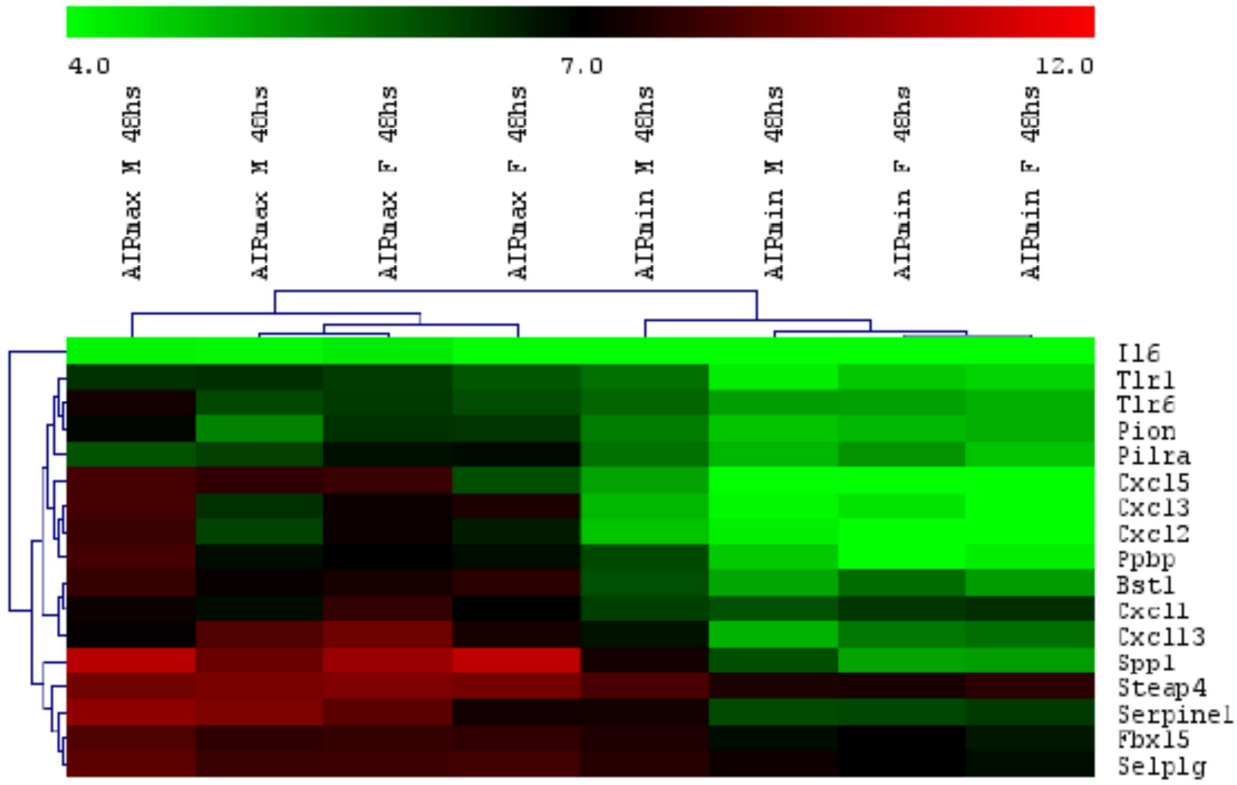


B)

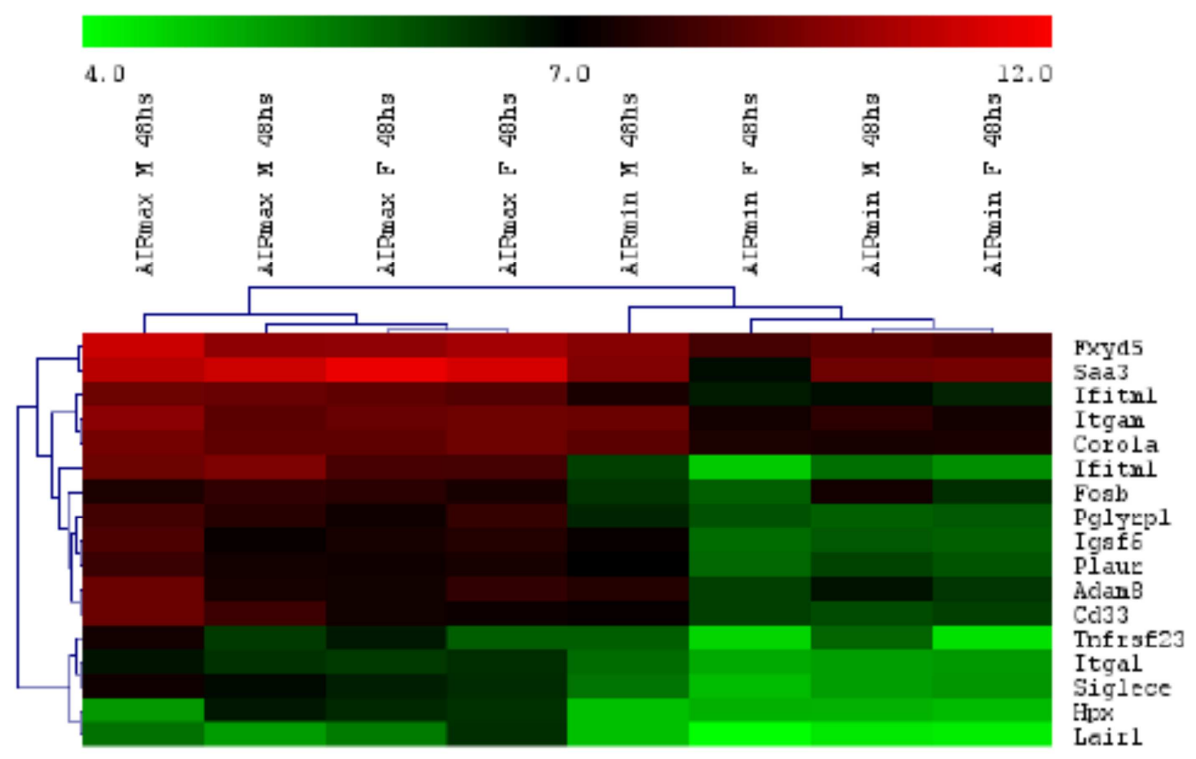

Genes mais expressos na linhagem AIRmax em relação a linhagem AIRmin e agrupados nos cromossomos $5(A)$ e $7(B)$, após 48 horas da aplicação de Biogel. A diferença de expressão foi calculada utilizando programa de análise de significância de microarray (SAM) para uma taxa de falsa detecção (FDR) $<5 \%$ considerando uma diferença mínima de 2 vezes para os genes diferentemente expressos.

Fonte: (FERNANDES, 2012)

\subsection{ANÁLISE DA EXPRESSÃO GÊNICA POR PCR EM TEMPO REAL}

A análise de diferenças na expressão gênica relativa pelo método de PCR em Tempo Real, também foi realizada.

Os animais foram injetados subcutaneamente com $0,75 \mathrm{ml}$ de uma suspensão de Biogel P-100 na região dorsal, e 48 horas e 30 dias depois, o tecido do local de aplicação foi extraído e submetido ao protocolo de extração de RNA para posterior síntese de cDNA, o qual foi utilizado para as reações de qPCR.

O valor do gene alvo de cada amostra foi normalizado pela subtração do valor do gene constitutivo, neste caso a Ciclofilina $(\Delta \mathrm{Ct})$ e calibrados pela subtração dos valores de $\Delta \mathrm{Ct}$ dos animais AIRmin controle, que foram utilizados como calibradores comuns para todas as reações. Os resultados a seguir são dados pelos valores de $2^{-\Delta \Delta \mathrm{Ct}}$ como descrito em materiais e métodos.

Os genes escolhidos para a realização do ensaio foram genes baseados nos dados do microarray e envolvidos com o processo inflamatório, tanto para a confirmação dos resultados observados no período de 48 horas, como para avaliar as diferenças de expressão gênica desses genes no período de 30 dias. Dessa 
forma, os seguintes genes foram avaliados: as citocinas e quimiocinas inflamatórias Tnfa, I11 $\beta, 116, C x c / 1, C x c / 2, C c / 2, T g f \beta$, o receptor de quimiocina $C x c r 2$, as moléculas de adesão celular Itgb2 e Vcam-1 e a metaloproteinase Mmp9.

A expressão das citocinas pró-inflamatórias Tnfa, $1 / 6$ e Il1b (Figura 15) foram significativamente maiores nos animais AIRmax comparados a seus controles e aos animais AIRmin no período de 48 horas, diminuindo esses níveis após 30 dias de estímulo, exceto pela expressão de Tnfa, que não é estatisticamente diferente do período anterior. Os camundongos AIRmin injetados com Biogel mantiveram os níveis de expressão de Tnfa e ll6 basais e iguais aos seus controles nos 2 períodos avaliados. Já para o transcrito de $/ 11 \mathrm{~b}$, esses camundongos mostraram diferenças intra-linhagem, sendo que em 48 horas sua expressão foi maior que nos outros dois períodos.

Figura 15 - Expressão relativa dos genes Tnfa, //6 e //1b

Tnfa

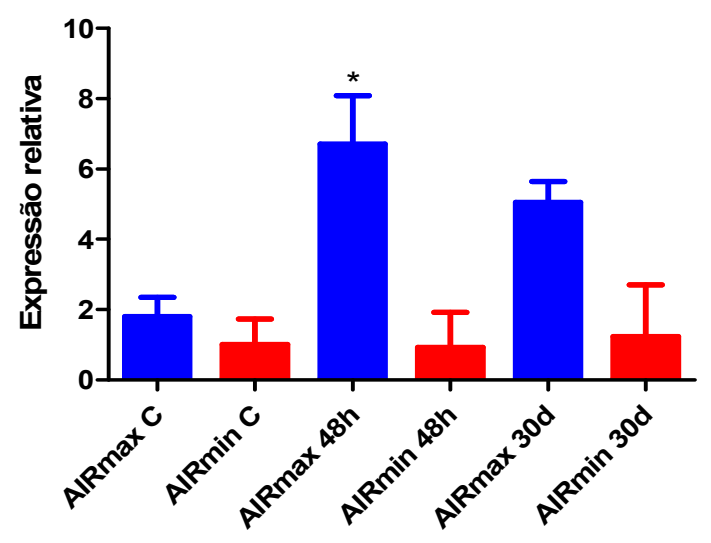

116

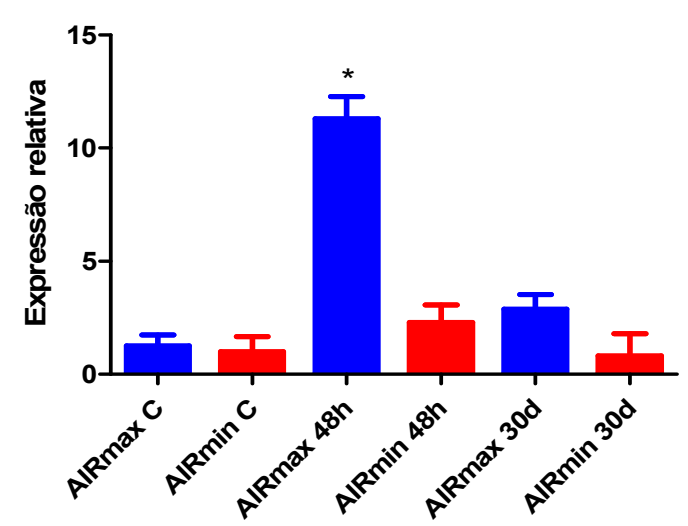

"116

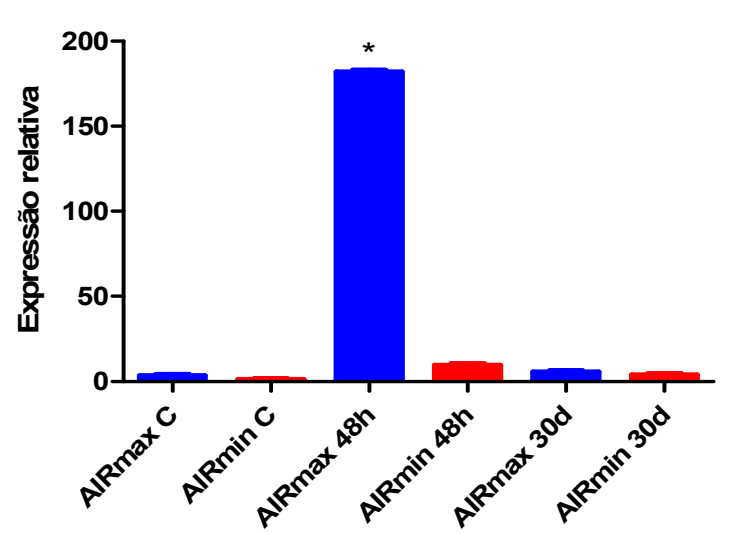

Expressão relativa dos genes Tnfa, $/ 16$ e $/ / 1 \mathrm{~b}$ realizadas por PCR em tempo real a partir do mRNA extraído do tecido subcutâneo de animais AIRmax e AIRmin controle e após 48 horas e 30 dias da injeção de Biogel P-100 no dorso desses animais ( $n=4$ camundongos por grupo). Os dados são expressos como médias \pm desvio padrão da média e análise estatística por ANOVA. * $p<0.05$ - entre camundongos AIRmax e AIRmin.

Fonte: (FERNANDES, 2012) 
Nos animais AIRmax as quimiocinas $\mathrm{Cxc} / 1$ e $\mathrm{Cxc} / 2$, tiveram seus níveis de expressão significativamente maiores do que nos animais AIRmin após 48 horas, sendo que para a quimiocina $C x c / 2$ esses níveis foram de cerca de 19 vezes de diferença (Figura 16). Esses valores foram menores no período de 30 dias, porém ainda significativos se comparados com os controles e com os animais AIRmin, para ambas as citocinas. Este último por sua vez, somente teve a expressão aumentada de $C x c / 2$, e após 48 horas de estímulo inflamatório com Biogel. A expressão do receptor $C x c r 2$, só apareceu aumentada nos camundongos AIRmax após 48 horas.

Figura 16 - Expressão relativa dos genes $C x c / 1, C x c / 2$ e $C x c r 2$

\section{Cxcl1}

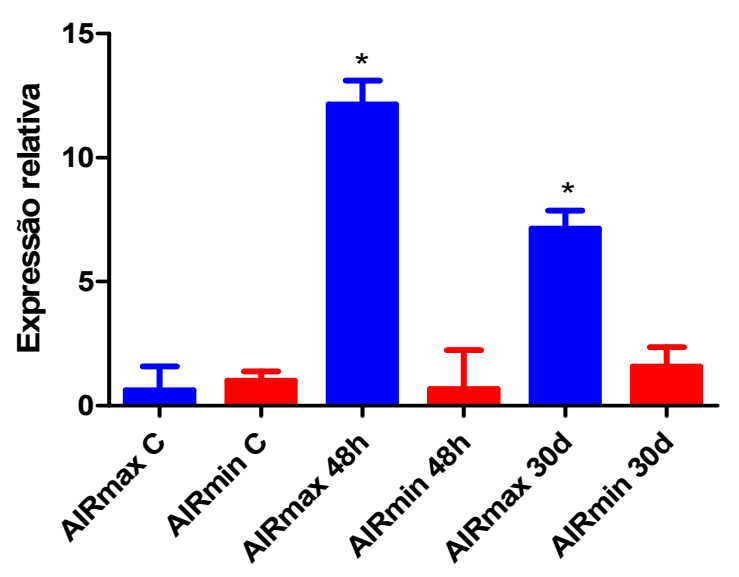

Cxc/2

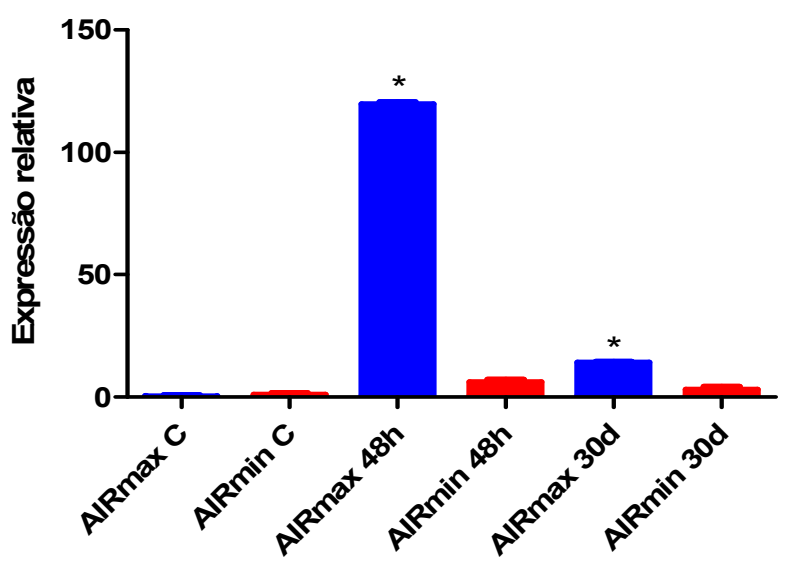

Cxcr2

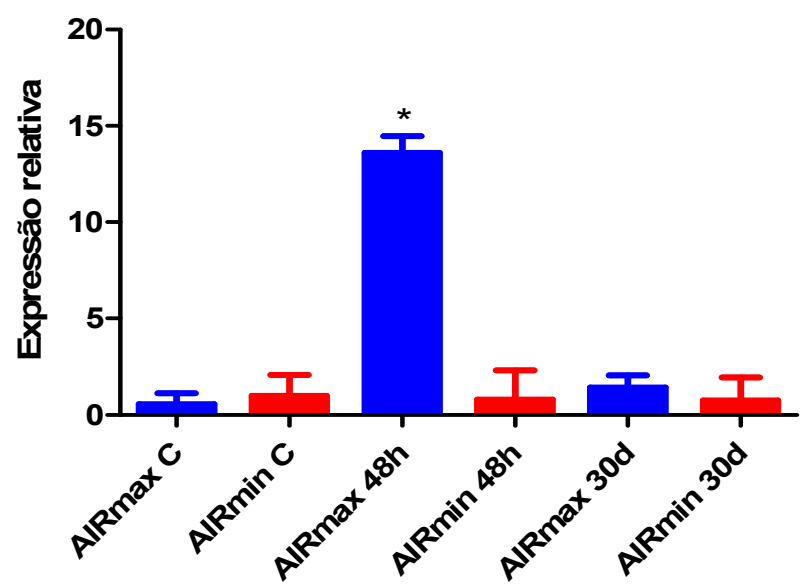

Expressão relativa dos genes $C x c / 1, C x c / 2$ e $C x c r 2$ realizadas por PCR em tempo real a partir do mRNA extraído do tecido subcutâneo de animais AIRmax e AIRmin controle e após 48 horas e 30 dias da injeção de Biogel P-100 no dorso desses animais ( $n=4$ camundongos por grupo). Os dados são expressos como médias \pm desvio padrão da média e análise estatística por ANOVA. * $p<0.05$ entre camundongos AIRmax e AIRmin.

Fonte: (FERNANDES, 2012) 
Já para a quimiocina $C c / 2$, os animais AIRmax tiveram expressão aumentada em 9 vezes se comparados com os animais AIRmin em 48 horas (Figura 17), tendo expressão ainda maior em 30 dias de estímulo contínuo. Os animais AIRmin, mostraram expressão não variável dessa quimiocina durante todos os períodos avaliados. O perfil de expressão de ltgb2 foi similar ao das quimiocinas $\mathrm{CxCl1}$ e Cxc/2, sendo estatisticamente maior nos animais AIRmax experimentais após 48 horas do que nos basais e do que nos animais AIRmin (Figura 18). Aos 30 dias, apesar de apresentar uma leve queda, o Itgb2 continua sendo mais expresso nos animais bons respondedores. Os camundongos AIRmin, não mostraram diferenças estatísticas de expressão em nenhum dos períodos avaliados.

Figura 17 - Expressão relativa dos genes Ccl2 e ltgb2

\section{$\mathrm{Ccl} 2$}

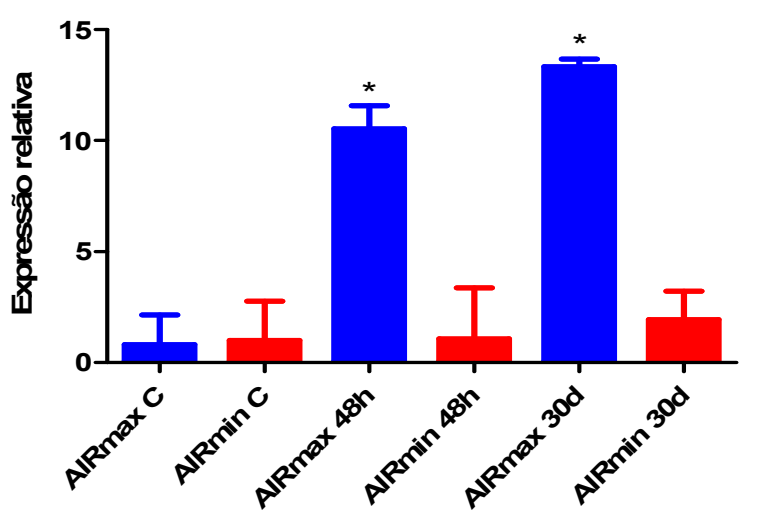

Itgb2

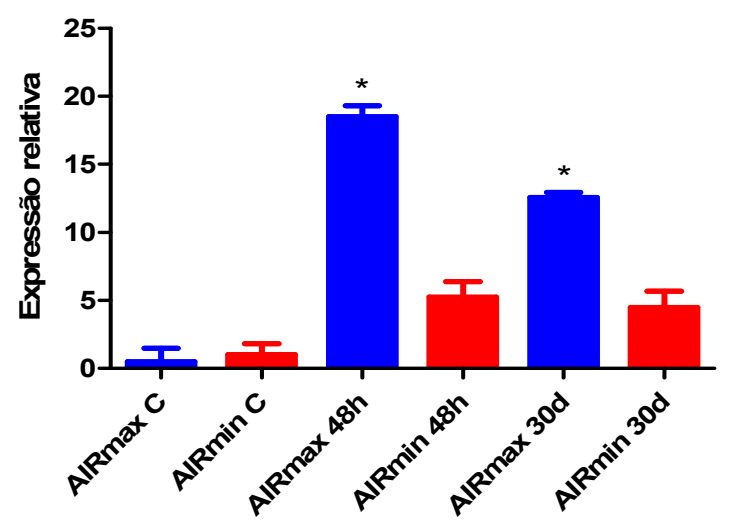

Expressão relativa dos genes $C c / 2$ e ltgb2 realizada por PCR em tempo real a partir do mRNA extraído do tecido subcutâneo de animais AIRmax e AIRmin controle e após 48 horas e 30 dias da injeção de Biogel P-100 no dorso desses animais ( $n=4$ camundongos por grupo). Os dados são expressos como médias \pm desvio padrão da média e análise estatística por ANOVA. * $p<0.05$ - entre camundongos AIRmax e AIRmin.

Fonte: (FERNANDES, 2012) 
Nós avaliamos também a expressão da citocina anti-inflamatória Tgfb e da molécula de adesão Vcam1 (Figura 19). Nos períodos iniciais não houve diferença nos animais experimentais entre as linhagens assim como os seus respectivos controles para ambos os genes. Aos 30 dias, os camundongos da linhagem AIRmax mostram aumento nos níveis dessas moléculas, apesar do aumento para o transcrito do $T g f b$, não ter sido significativo entre as linhagens. Os animais AIRmin não mostraram diferença de expressão em nenhum dos períodos avaliados.

Figura 18 - Expressão relativa dos genes Tgfb e Vcam1

Tgfb

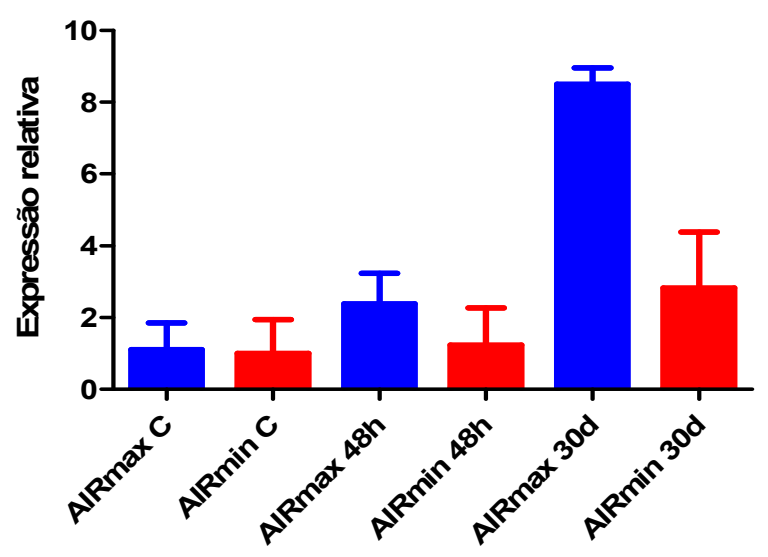

Vcam1

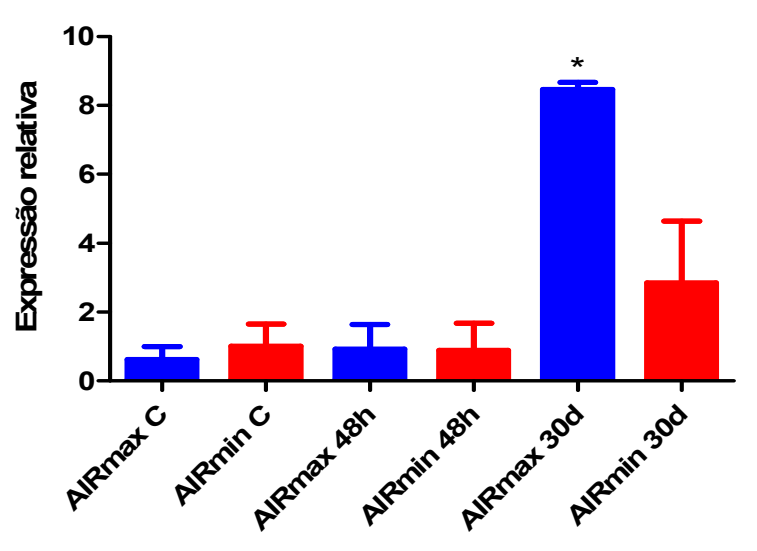

Expressão relativa dos genes Tgfb e Vcam1 realizadas por PCR em tempo real a partir do mRNA extraído do tecido subcutâneo de animais AIRmax e AIRmin controle e após $48 \mathrm{~h}$ e 30 dias da injeção de Biogel P-100 no dorso desses animais ( $n=4$ camundongos por grupo). Os dados são expressos como médias \pm desvio padrão da média e análise estatística por ANOVA. * $p<0.05$ - entre camundongos AIRmax e AIRmin.

Fonte: (FERNANDES, 2012)

Como observado na Figura 20, os animais AIRmin submetidos ao protocolo de aplicação do Biogel não tiveram expressão da enzima Metaloproteinase-9 em nenhum dos períodos enquanto os animais AIRmax tiveram um aumento de expressão em 48 horas, diminuindo esses valores no $30^{\circ}$ dia, onde os valores não são mais significativos se comparados com a linhagem oposta. 
Figura 19 - Expressão relativa do gene $M m p 9$

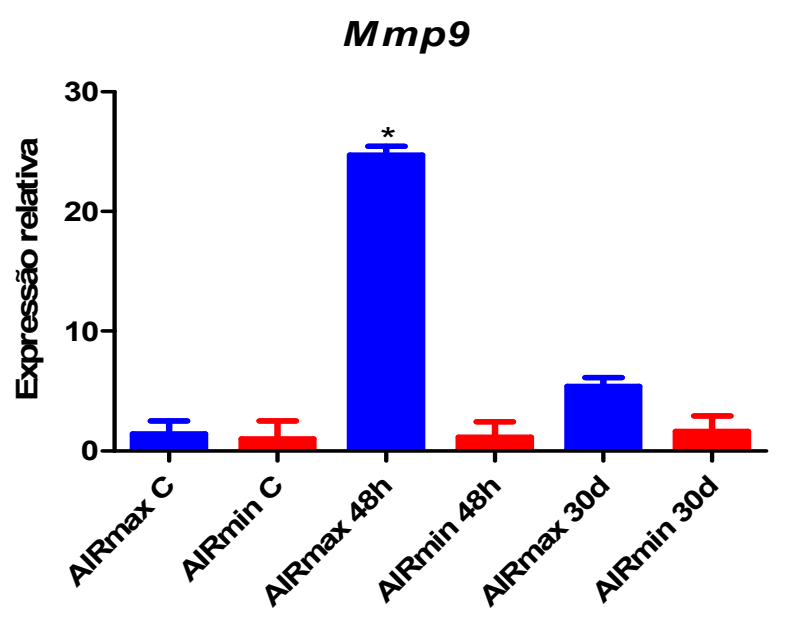

Expressão relativa do gene Mmp9 realizada por PCR em tempo real a partir do mRNA extraído do tecido subcutâneo de animais AIRmax e AIRmin controle e após 48 horas e 30 dias da injeção de Biogel P-100 no dorso desses animais ( $n=4$ camundongos por grupo). Os dados são expressos como médias \pm desvio padrão da média e análise estatística por ANOVA. * $p<0.05$ - entre camundongos AIRmax e AIRmin.

Fonte: (FERNANDES, 2012)

\subsection{ANÁLISE MACRO E MICROSCÓPICA DA PELE}

Para aprofundar o nosso conhecimento sobre as linhagens, nós avaliamos também as condições histológicas do tecido subcutâneo dos animais submetidos ao protocolo de aplicação do Biogel para poder visualizar a infiltração celular local.

Os animais injetados subcutaneamente com a suspensão de Biogel P-100 $(0,75 \mathrm{ml})$ na região dorsal, foram mortos 48 horas e 30 dias depois, e a pele local da aplicação foi retirada e passada por um processo de inclusão em parafina, como descrito em materiais e métodos. Os cortes com espessura de $5 \mu \mathrm{m}$ foram feitos em micrótomo e as lâminas coradas com HE. A leitura foi feita em microscópio ótico.

A análise macroscópica do tecido subcutâneo dos animais AIRmax após 48 horas, mostrou um quadro de hiperemia (Figura 20B). Nesses mesmos animais aos 30 dias, após coleta do exsudato e observação da pele no local onde o Biogel foi injetado, formou-se uma espécie de tecido secundário (Figura 20C) que foi descrito como sendo um possível granuloma pela veterinária patologista, Dra. Claudia Ferreira. Os animais AIRmin estimulados por 48 horas e 30 dias não mostraram alterações macroscópicas à observação do tecido (Figuras 20E e F). 
À análise microscópica, o laudo da patologista veterinária, Dra. Claudia Ferreira, revelou aumento na espessura da pele e tecido subcutâneo caracterizado por um infiltrado inflamatório difuso de neutrófilos, eosinófilos e poucos macrófagos em meio a vasos congestos com marginação leucocitária na derme profunda, o qual se estendeu até o subcutâneo de animais AIRmax inflamados por 48 horas. Foi observado ainda edema e focos de material amorfo e basofílico envolto por neutrófilos no tecido subcutâneo (Figura 21C). Já nos animais AIRmin, no mesmo período, a derme profunda revelou discreto infiltrado inflamatório focal de linfócitos e macrófagos. No tecido subcutâneo foi possível evidenciar discreto infiltrado inflamatório linfocitário e profundamente, foi possível vizualizar infiltrado inflamatório difuso e discreto de neutrófilos, linfócitos e poucos eosinófilos (Figura 21D).

Após 30 dias de estímulo com Biogel, mastócitos perifolicular e intersticiais foram encontrados na derme profunda e no tecido subcutâneo de animais AIRmax, sendo que no subcutâneo ainda foi possível evidenciar intenso infiltrado inflamatório de neutrófilos, macrófagos e células gigantes multinucleadas envolvendo material amorfo e basofílico (Biogel) (Figura 21E). A análise da derme profunda dos animais AIRmin mostrou infiltrado inflamatório discreto de neutrófilos e linfócitos permeados por mastócitos enquanto no subcutâneo houve presença de mastócitos esparsos e formação de edema com infiltrado inflamatório moderado e difuso de linfócitos, macrófagos e células gigantes multinucleadas envolvendo focos de material amorfo e basofílico (Biogel), além de vasos congestos e ectásicos (Figura 21F). 
Figura 20 - Macroscopia do tecido subcutâneo dos camundongos AIRmax e AIRmin

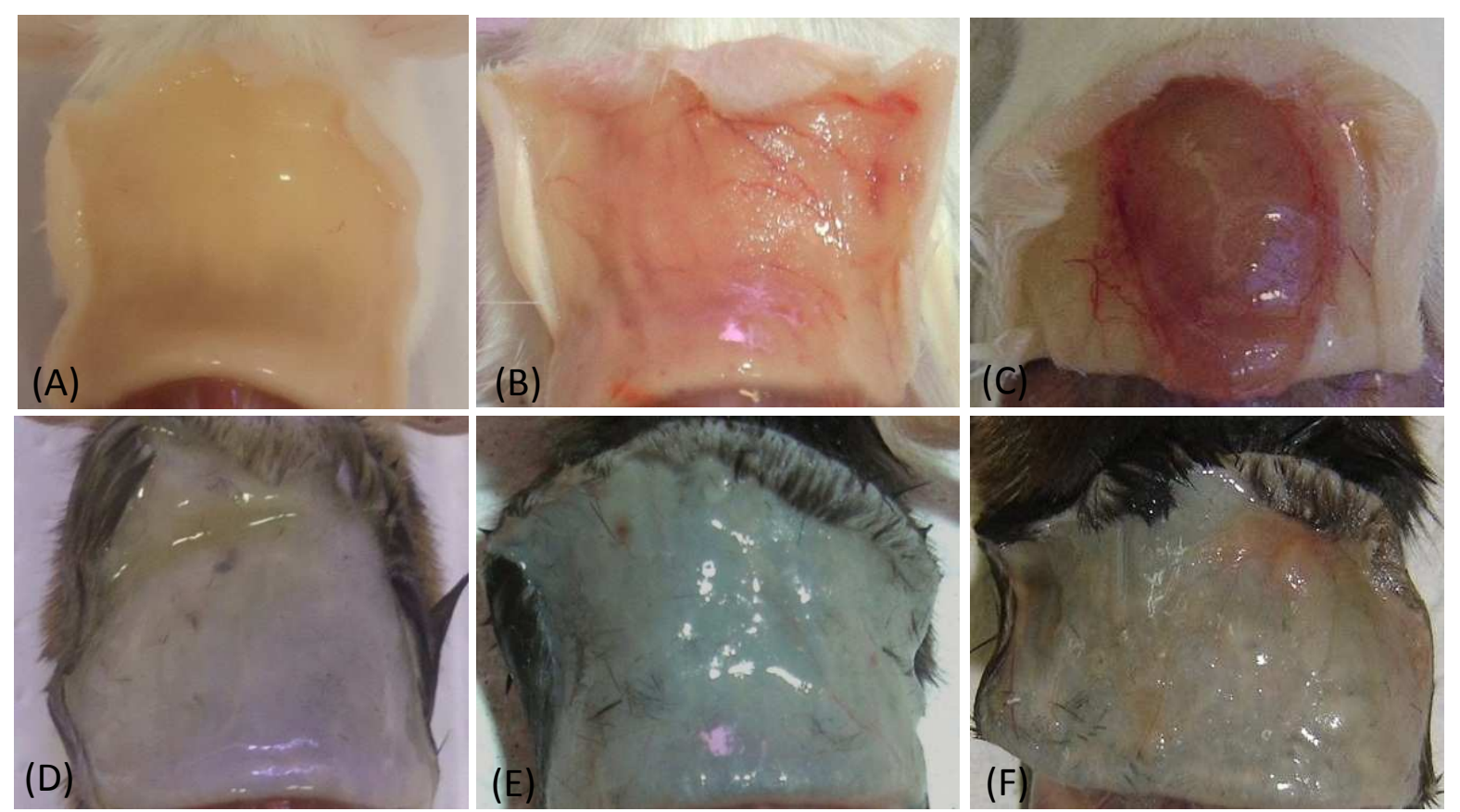

Tecido subcutâneo dos camundongos AIRmax controle (A) ou estimulado com Biogel por 48 horas (B) ou por 30 dias (C) e camundongos AIRmin controle (D) ou estimulado com Biogel por 48 horas (E) ou 30 dias $(F)$.

Fonte: (FERNANDES, 2012)

Figura 21 - Cortes histológicos do tecido subcutâneo de animais AIRmax e AIRmin
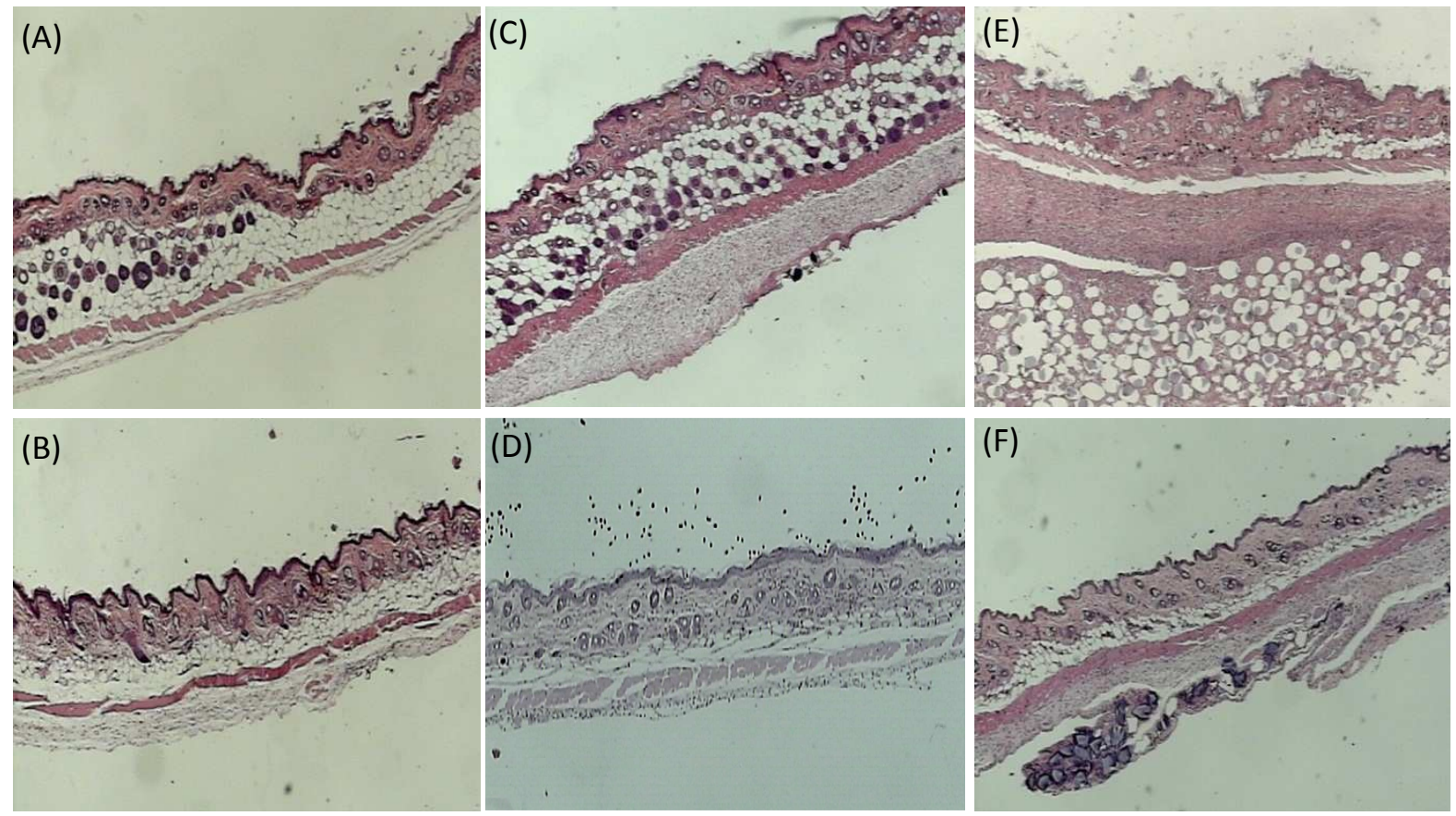

Secções do tecido subcutâneo de animais AIRmax e AIRmin controles e injetados com Biogel no dorso dos camundongos. As fotos foram capturadas em microscópio óptico com objetiva de 10X. Animais AIRmax (A) e AIRmin (B) basais. Animais AIRmax 48 horas (C) e 30 dias (E) após aplicação de Biogel. Animais AIRmin 48 horas (D) e 30 dias (F) após aplicação de Biogel.

Fonte: (FERNANDES, 2012) 


\section{DISCUSSÃO}

As linhagens AIRmax e AIRmin foram desenvolvidas com o intuito de se estudar o controle genético da resposta inflamatória aguda e identificar genes envolvidos com esse fenótipo. As linhagens foram selecionadas com base na concentração proteica e infiltração celular, caracterizada principalmente por células polimorfonucleares, após 24 horas da injeção de Biogel, com uma deteç̧ão maior de ambos os fenótipos na linhagem AIRmax, ao final da seleção. Essa diferença interlinhagens resultou do acúmulo de alelos dotados com efeitos opostos e aditivos na resposta inflamatória. Além disso, no trabalho de Ribeiro et al. (2003), foi observado que os animais AIRmax tem aumentada produção de fatores quimiotáticos atraentes de neutrófilos no exsudato local, com maior produção dessas células na medula óssea e maior resistência das mesmas à apoptose no local de extravasamento após 24 horas da injeção de Biogel. Seguindo o mesmo protocolo de aplicação de Biogel foi demonstrado em outro trabalho, um distinto perfil de expressão gênica na medula óssea desses animais com uma ampla ativação de transcritos de genes na linhagem AIRmax e ampla repressão de transcritos nos animais AIRmin (CARNEIRO et al., 2009). A expressão diferencial desses transcritos envolvidos com resposta inflamatória, transdução de sinal, comunicação celular entre outros, pode estar envolvida diretamente com a modificação dos três elementos observados no trabalho de Ribeiro et al. (2003), e citados anteriormente.

A pressão seletiva oposta a que as linhagens AIRmax e AIRmin sofreram durante a seleção, também modificou a resistência ou susceptibilidade dessas linhagens a certas patologias. Os animais AIRmax foram mais resistentes à infecção bacteriana por Salmonella Typhimurium (ARAÚJO et al., 1998) e ao desenvolvimento de carcinogênese de pele e de pulmão induzida por agentes químicos (BIOZZI et al., 1998; RIBEIRO et al., 2005). Por outro lado, foram mais susceptíveis que os animais AIRmin ao desenvolvimento de artrite induzida por pristane (VIGAR et al., 2000) e carcinogênese de colón (DI PACE et al., 2006), além de vários outros fenótipos que também foram modificados nessas linhagens.

Baseando-nos nessas diferenças fenotípicas e de expressão de genes modificadas na medula óssea da linhagem AIR, no presente trabalho nós decidimos pesquisar as modificações ocorridas diretamente no tecido subcutâneo que esteve 
em contato com o Biogel por 48 horas ou 30 dias. Com esse protocolo foi possível observar o comportamento das linhagens frente a um estímulo agudo e crônico local, visando estabelecer se a seleção genética que afetou a resposta inflamatória aguda nesses camundongos também pode ter afetado o desenvolvimento de uma resposta inflamatória crônica às partículas de poliacrilamida. Além disso, os genes diferencialmente expressos no tecido subcutâneo das linhagens também foram correlacionados com os QTL previamente mapeados, que vão ser discutidos mais adiante.

Apesar de o infiltrado celular e proteico no exsudato estar bem estabelecido nessas linhagens no período agudo (24 e 48 horas), não sabíamos como elas se comportariam com um estímulo com Biogel mais prolongado, como após 30 dias. Os nossos resultados mostraram que da mesma forma que no período de 48 horas, após 30 dias os animais AIRmax continuam com o número de células significativamente maior que nos animais AIRmin, porém com uma mudança no perfil de infiltração celular passando de neutrófilos para macrófagos, uma mudança que também observamos nos camundongos AIRmin (Figura 3). Essa mudança no recrutamento celular é o principal evento que caracteriza a transição de uma resposta inflamatória aguda para uma resposta inflamatória crônica (KAPLANSKI et al., 2003). Isso nos mostra que mesmo em um período mais tardio, ou em uma resposta crônica, os animais AIRmax mantêm sua maior capacidade de produzir células e responder ao agente inflamatório. Um dado interessante, foi que em ambos os períodos, os camundongos AIRmin mostraram uma maior porcentagem na infiltração de eosinófilos (Figura 3B). Apesar de serem menos comuns que neutrófilos e macrófagos, é certo que os eosinófilos podem participar de respostas inflamatórias desencadeadas por agentes microbianos ou não, estimulando a inflamação por diversas ações, mas principalmente pela liberação de mediadores pré-formados de seus grânulos (GONLUGUR; GONLUGUR, 2006; ROTHENBERG; HOGAN, 2006). Essa infiltração foi relativamente pequena e a sua relevância para o desenvolvimento do processo inflamatório desenvolvido por essas linhagens deve ser melhor verificado.

As citocinas inflamatórias TNF- $\alpha, \mathrm{IL}-1 \beta$, IL-6 e CCL2 (MCP-1) também foram encontradas em níveis elevados no exsudato da linhagem boa respondedora, após 48 horas (Figura 4), provavelmente contribuindo para o perfil de infiltração celular 
observado nessa linhagem. Porém após 30 dias, esses níveis se mostraram diminuídos e permaneceram próximo a seus basais. Interessantemente nos animais controles injetados com salina, diferente do que foi visto para as outras citocinas, foi observada a presença de CCL2 no subcutâneo de ambas as linhagens, sendo significativamente maior nos AIRmax do que nos AIRmin (Figura 4D). Essa deteç̧ão pode ser explicada pelo fato de que a injeção de ar no subcutâneo desses animais por si só, poderia estar induzindo uma pequena resposta inflamatória nesses animais, que seria então capaz de estimular a secreção de alguns mediadores da inflamação.

Para melhor verificar as diferenças entre as duas linhagens e em ambos os períodos inflamatórios, nós utilizamos o tecido subcutâneo que esteve em contato com Biogel para realizar experimentos de expressão gênica global e relativa. Com os experimentos de microarray realizados para medir níveis de expressão de transcritos em larga escala foi possível identificar genes ativados ou reprimidos em ambas as linhagens após o tratamento com o Biogel e genes diferentemente expressos entre as linhagens. Além disso, foi possível agrupar os genes diferentemente expressos em temas biológicos de acordo com sua categoria funcional através do programa EASE.

De acordo com a grande quantidade de neutrófilos encontrados no exsudato inflamatório dos animais AIRmax, após 48 horas de indução inflamatória com Biogel, nós observamos ativação na transcrição da quimiocina $C x c / 2$ no tecido subcutâneo dessa linhagem em relação ao seu basal (Figura 7A) e maior expressão gênica das quimiocinas Cxc/2 e Cxcl1 em relação aos animais AIRmin (Figura 11A). Esses resultados foram ainda confirmados por PCR em tempo real, que também mostrou uma maior expressão desses genes na linhagem AIRmax após o período de 30 dias (Figura 16). Essas quimiocinas são conhecidas por sua forte ação quimiotática sobre neutrófilos e se ligam ao seu receptor murino CXCR2 (IL8RB) que também está ativado e mais expresso nessa linhagem do que na linhagem oposta. Ribeiro et al. (2003), mostraram que em condições estáveis os animais AlRmax tem maiores quantidades de neutrófilos no sangue do que os AIRmin, e sugeriu que a seleção genética pode ter resultado em uma capacidade diferencial da medula óssea desses animais de produzir e exportar neutrófilos. Diferença na expressão de ambas as citocinas $C x c / 1$ e $C x c / 2$ e de seu receptor, também foi observada na medula óssea 
de animais AIRmax e AIRmin controles e tratados com Biogel por 24 horas (CARNEIRO et al., 2009), mostrando que a seleção genética induziu uma diferença quanto à produção de quimiocinas atraentes de neutrófilos na medula, ainda em condições basais.

Outros genes ativados na pele da linhagem boa respondedora agruparam-se principalmente nas categorias de genes envolvidos com transdução de sinal, resposta inflamatória e resposta imune incluindo citocinas, quimiocinas e seus receptores como I11b, Tnfa, II6, Cc/2, Cc/3, Cc/8, Cxcl5, Ccr1, Ccr2 (Figuras 7A, 8A e 9). Esses resultados não nos surpreendem desde que, como visto anteriormente, observamos uma intensa infiltração celular nesses animais no local de aplicação de Biogel, que pode estar sendo influenciada pela expressão de tais citocinas. Esses camundongos mostraram ainda ativação de genes pertencentes à família de receptores semelhantes à Toll, como TIr1, TIr2, TIr4, TIr6, TIr7, TIr13 e ainda da molécula de sinalização intracelular Myd88 (Figura 8A). Os receptores do tipo Toll são receptores de reconhecimento padrão (PPRs) que reconhecem padrões moleculares presentes nos patógenos, mas que também são capazes de reconhecer componentes não associados a patógenos liberados durante a injúria tecidual. $A$ ligação desses PRRs ativa uma cascata de sinalização intracelular via Myd88, que é utilizado por todos os TLRs exceto pelo TLR3 (PRINCE et al., 2011). Esse caminho leva à ativação de fatores de transcrição como o NFkB e MAPK que resultam na transcrição de genes responsáveis pela produção de citocinas pro-inflamatórias e quimiocinas que são importantes para o início da resposta (CHEN; NUÑEZ, 2010).

Os genes ativados e sobre-representados na linhagem AIRmin aparecem nas mesmas categorias biológicas observadas nos animais AIRmax: transdução de sinal, resposta imune e resposta inflamatória (Figuras 7B e 8B). A maioria desses genes também apareceu ativado nos camundongos AIRmax como o Cc/3, Cc/12, Ccr2, Ccr5, TIr13, TIr7, Tnfrsf1b e Cd180 (Figuras 7A, 8A e 9). Porém esses últimos mostraram uma ativação de genes cerca de quatro vezes maior que na linhagem oposta com 488 genes ativados enquanto a linhagem AlRmin mostrou ativação de 108 genes (Tabela 3). Mesmo com menor expressão de mediadores inflamatórios que os AIRmax, esses camundongos tem capacidade de desenvolver uma resposta inflamatória aparentemente normal, embora em intensidade bem menor. De fato, Ribeiro et al. (2003), demonstrou que quando estimulados com o exsudato dos 
AIRmax, a quimiotaxia de neutrófilos da medula óssea dos animais AIRmax e AIRmin não foi diferente, mostrando portanto que os AIRmin tem a mesma capacidade de responder a fatores quimiotáticos que os animais AIRmax.

A expressão de genes envolvidos com a reposta imune, resposta inflamatória, transdução de sinal, adesão celular, quimiotaxia e proteólise como Tnfa, $/ / 1 b$, //6, Cxcl5, Ccl8, Tnfrsf1, TIr1, TIr2, TIr6, TIr13, Itgb2, Itgam, Itgal (Figura 11) e as metaloproteinases Mmp8 e Mmp9 (Figura 12C), foi maior nos camundongos AIRmax injetados com Biogel do que nos camundongos AIRmin. Além de mais expressas pelo método de microarray, algumas dessas citocinas também apareceram mais expressas nos camundongos AIRmax por ensaio de PCR em tempo real portanto confirmando os dados de microarray.

O gene Slc11a1 também foi mais expresso nos animais AIRmax do que nos AIRmin (Figura 12A). Este gene presente no cromossomo 1 é um forte gene candidato e tem sido amplamente estudado pelo nosso grupo em trabalhos com as sublinhagens homozigotas para $\mathrm{O}$ alelo $\mathrm{R}$ de resistência e para $\mathrm{O}$ alelo $\mathrm{S}$ de susceptibilidade. A substituição do aminoácido glicina por ácido aspártico na posição 169 do códon, confere um fenótipo de susceptibilidade a diferentes infecções em camundongos, decorrente da falta de função dessa proteína (VIDAL et al., 1995). Essa falta de função acarreta em acúmulo de íons no interior do fagossomo, favorecendo a replicação de patógenos. Esse gene é expresso principalmente em macrófagos e neutrófilos, e tem efeitos pleotrópicos na função dessas células. Está envolvido com a indução e manutenção da autoimunidade, câncer e principalmente com a resistência a patógenos intracelulares (AWOMOYI, 2007). As sublinhagens desenvolvidas com os alelos em homozigose para a proteína funcional ou não, mostram diferenças quanto à inflamação após aplicação de Biogel, desenvolvimento de artrite experimental induzida por pristane (PETERS et al., 2007), choque endotóxico com LPS, infecção com a bactéria intracelular Salmonella Typhimurium (BORREGO et al., 2006) e regeneração tecidual (DE FRANCO et al., 2007), mostrando que esse gene pode estar envolvido na regulação da inflamação e de outros eventos ligados a mesma. O gene Cxcr2 (I/8rb), já descrito anteriormente, está localizado na mesma região que o Slc11a1, portanto pode ser também um possível gene candidato (Mouse Genomic Informatics, 2012). 
Entre as categorias de genes sobre-representados e mais expressos nos animais AIRmin estão alguns genes envolvidos com resposta imune, regulação da contração muscular e organização do citoesqueleto sendo que somente 3 genes estiveram presentes em cada categoria. Um desses genes envolvidos com resposta imune, é o gene Cc/24 ou eotaxina 2 (Figura 13). Esse gene codifica uma quimiocina que tem funções análogas à eotaxina e age atraindo eosinófilos e basófilos ao local inflamado (FORSSMANN et al., 1997).

Entre os genes reprimidos na linhagem AIRmax estão genes envolvidos com contração muscular e organização do citoesqueleto (Figura 10). Alguns desses genes sobre-representados na categoria de contração muscular, mostraram estar envolvidos com o processo de resolução de uma injúria, sendo importantes na diferenciação de fibroblastos em miofibroblastos que contribuem com a formação de cicatriz nos processos de reparo ao invés de regeneração do tecido (NOWAK et al., 2009). Interessantemente os camundongos AIRmax, após uma perfuração de $2 \mathrm{~mm}$ na orelha, foram capazes de reparar completamente o tecido, enquanto os camundongos AIRmin não mostraram fechamento do furo (DE FRANCO et al., 2007). Além disso, os trabalhos de Frénal e Soldati-Favre (2009) e Carabeo et al. (2002) mostraram que a organização do citoesqueleto é importante para garantir a entrada, desenvolvimento e egresso de alguns agentes patogênicos, como protozoários e bactérias. Nos modelos experimentais de infeção com o parasita Trypanosoma Cruzi (Dados não publicados) e com a bactéria intracelular Salmonella Typhimurium (BORREGO et al., 2006) nessas linhagens, os camundongos AIRmax mostraram-se mais resistentes que os camundongos AIRmin. Dessa forma, a repressão desses genes, na linhagem AIRmax pode ser importante tanto para a diminuição da formação de cicatriz após uma injúria, quanto um mecanismo de defesa para evitar uma infecção por certos agentes microbianos.

A identificação desses genes diferentemente expressos entre as linhagens também tem sido utilizada para correlacionar com QTLs (quantitative trait loci) previamente mapeados em outros trabalhos do nosso grupo. Análise de polimorfismos utilizando marcadores SNP detectou dois significantes QTLs para o número de células infiltrantes no cromossomo 5 e 7 , assim como alguns sugestivos nos cromossomos 2, 4, 6 11, 12 e 16 (GALVAN et al., 2011). 
Diferença na expressão de $I L-1 b$ e de $N r / p 3$, por exemplo, foi vista no transcriptoma da pele das linhagens após aplicação de Biogel, com expressão maior nos animais AIRmax do que nos AIRmin (Figuras 11A e 12B). O NRLP3 é um receptor que faz parte da família de receptores do tipo NOD (NRLs), que estão presente no citoplasma das células e são capazes de reconhecer PAMPs e DAMPs e assim dar início a resposta inflamatória (MARTINON; MAYOR; TSCHOPP, 2009). A ativação desse receptor junto com a proteína adaptadora ASC e caspase-1 são responsáveis pela formação do inflamassoma Nalp3 que é descrito por reconhecer principalmente componentes não microbianos da inflamação. A montagem deste inflamassoma leva à ativação da caspase-1 que por sua vez cliva a pro-IL1 $\beta$ em sua forma biologicamente ativa. A IL-1 $\beta$ é uma importante citocina pró-inflamatória que tem efeitos pleiotrópicos na defesa do hospedeiro. É capaz de regular respostas de fase aguda ao dano tecidual assim como estimular a produção de outras citocinas e quimiocinas, envolvidas com essa resposta (LEEMANS; CASSEL; SUTTERWALA, 2011; WEBER; WASILIEW; KRACHT, 2010).

O trabalho de Vorraro et al. (2010), detectou um QTL altamente significante no cromossomo 7 envolvido com o número de células infiltrantes no exsudato após 24 horas da injeção de Biogel e a produção de IL-1 $\beta$ ex vivo após a estimulação com LPS e ATP. Apesar desses fenótipos serem distintos, eles são estatisticamente correlacionados em intercruzamentos F2 de camundongos AIRmax e AIRmin, indicando sua modulação por um locus comum. Este locus encontrado no cromossomo 7 foi designado como Irm1 (inflammatory response modulator 1). Essa região contém uma série de genes envolvidos com a regulação da resposta inflamatória, entre eles, genes responsáveis pelo tráfico e recrutamento de leucócitos como Itgam e Itgal, que também foram mais expressos no transcriptoma dos animais AIRmax do que no dos animais AIRmin no presente trabalho. Um locus no cromossomo 5, que foi chamado de Irm2 (inflammatory response modulator 2) também foi mapeado em outro trabalho pela análise de agrupamento e associação de haplótipos, e mostrou estar envolvido também com a infiltração de células e produção de IL-1ß (GALVAN et al., 2011).

Houve um agrupamento de genes significantes nos cromossomos 5 e 7 nos animais experimentais (Figura 14), sendo que os genes Itgam, Itgal, Igsf6 e Coro1a presentes no cromossomo 7 estão localizados na região do intervalo de confiança 
do locus Irm1, correlacionando com esse QTL previamente encontrado e podendo portanto, estar envolvidos na regulação da intensidade da AIR. O gene Itgam também foi diferencialmente expresso no transcriptoma da medula óssea das linhagens após 24 horas da injeção com Biogel (VORRARO et al., 2010).

No tecido dos camundongos AIRmax e AIRmin controles não houve diferenças intrínsecas expressivas no perfil de expressão gênica global, sendo que somente 29 genes foram mais expressos na linhagem AIRmax e 10 genes na linhagem AIRmin, e esses genes não pertenceram a nenhum agrupamento significativo (Tabela 4).

A combinação desses genes mais expressos nos animais AIRmax em relação aos AIRmin corrobora com a diferença na infiltração celular observada no exsudato $e$ no tecido dessas linhagens após aplicação do Biogel (Figuras 3 e 22C). Além disso, as citocinas TNF- $\alpha, \quad I L-1 \beta$, IL-6 e CCL2 também foram encontradas em concentrações significativamente elevadas no exsudato dos camundongos AIRmax após 48 horas (Figura 4), corroborando com os nossos dados de microarray e expressão gênica.

Os níveis de citocinas no soro também podem ser bastante informativos em alguns casos, pois a maioria das proteínas presentes no exsudato se origina do plasma. Os nossos resultados mostraram que a detecção de algumas citocinas no soro não esteve de acordo com os nossos dados de expressão gênica, microarray e dosagem das mesmas no exsudato. Isso pode se dever ao fato de que apesar dessas proteínas em sua maioria derivarem do plasma, parte delas podem também ser produzidas pelas células infiltradas no sítio inflamado. Diferenças significativas foram observadas somente na detecção das citocinas IL-10 e IL-17 no soro de camundongos AIRmax após 30 dias da injeção de Biogel (Figura 5). A presença da citocina IL-10 no soro da linhagem AIRmax, pode estar relacionada a um processo de resolução da resposta inflamatória desde que esse mediador age regulando a produção de citocinas inflamatórias por seus efeitos anti-inflamatórios e inibidores da resposta imune. Na resposta imune inata, essa citocina demonstra as suas propriedades anti-inflamatórias pela capacidade de inibir a síntese das citocinas próinflamatórias IL-1 $\alpha$, IL-1 $\beta$, IL-6, IL-8, TNF- $\alpha$, o fator de crescimento hematopoiético GM-CSF e o fator estimulante de colônia granulocítica G-CSF, por monócitos ativados. Porém a IL-10 não é capaz de suprimir a produção de IL-17 pelas células Th17 (MALEFYT et al., 1991; SABAT et al., 2010). A IL-17 é descrita entre outras 
funções, por participar de processos inflamatórios e de doenças inflamatórias crônicas autoimunes, sendo capaz de induzir a produção de algumas citocinas e quimiocinas inflamatórias como $\mathrm{Cxcl} 1, \mathrm{Ccl} 2, \mathrm{Ccl} 7, \mathrm{Ccl} 20$ e as metaloproteinases 3 e 13 e portanto mediando o recrutamento de neutrófilos e macrófagos durante a inflamação (ZHANG et al., 2011). Além das células Th17, células NK, NKT, neutrófilos e eosinófilos podem produzir IL-17 (KORN et al., 2009).

Em ambas as linhagens há uma mudança no perfil de infiltração celular * de neutrófilos para monócitos no exsudato depois de 30 dias de indução inflamatória (Figura 3). Nesse período a expressão de Tnfa, Ccl2, Itgb2 e Vcam1 estão aumentadas na linhagem AIRmax (Figuras 15, 17, 18 e 19), que também mostrou intenso infiltrado inflamatório de neutrófilos, macrófagos e células gigantes multinucleadas, à análise do tecido (Figura 22E) e do exsudato. A presença dessas células, principalmente de células gigantes e multinucleadas, pode favorecer a formação de granulomas.

Um granuloma é uma estrutura organizada formada por células imunes durante um estímulo inflamatório crônico. A formação de um granuloma é um processo ativo, no qual, células como macrófagos e linfócitos são continuamente recrutados do sangue para o tecido. Essas células não diferenciadas podem se dividir várias vezes in situ antes de sofrer apoptose ou retornar para a circulação (FLYNN; CHAN; LIN, 2011; WALLIS; EHLERS, 2005). A presença de corpos estranhos como no caso do Biogel, pode estimular a produção de um granuloma. A falta de marcadores de reconhecimento próprio nos corpos estranhos dispara mecanismos de fagocitose nos macrófagos, mas o seu tamanho e forma pode resultar numa tentativa frustrada de fagocitose. Assim, essas substâncias causam uma estimulação constante de células inflamatórias, principalmente de macrófagos, que não podendo formar a "cúpula fagocítica", se unem para formar células gigantes e multinucleadas para tentar encapsular o agente invasor e eliminá-lo, gerando, portanto, um granuloma (MEDZHITOV, 2008).

O TNF- $\alpha$ é importante na formação de granulomas e pode ser liberado nesse contexto tanto pelos macrófagos como pelas células T. Essa citocina age induzindo a ação antimicrobiana de macrófagos, promovendo a migração de vários tipos celulares e ainda a apoptose de leucócitos (WALLIS; EHLERS, 2005). Como observado anteriormente essa citocina continua sendo expressa nas linhagens 
AIRmax após 30 dias em concentrações não diferentes do período de 48 horas (Figura 15). A ação dessa citocina, junto com a expressão de $C c / 2$, que é uma importante quimiocina atraente de monócitos/macrógagos e de Vcam1 que é uma molécula de adesão que induz preferencialmente o extravasamento do mesmo tipo celular, podem estar contribuindo no local de aplicação de Biogel, para o recrutamento dessas células no tecido e exsudato. A infiltração de neutrófilos nesse período, observada na análise histológica, pode também ser em parte, consequência da expressão de $C x c / 1$ e $C x c / 2$, que embora estejam diminuídas no período de 30 dias com relação ao período de 48 horas, ainda são estatisticamente mais expressas que nos controles e do que na linhagem oposta (Figura 16). Diferente desse perfil, os camundongos AIRmin não expressam nenhuma dessas citocinas no período de 30 dias, e não mostraram alterações visíveis à observação macroscópica do tecido (Figura 21F), embora seja evidenciado também, um infiltrado inflamatório, porém discreto, ao exame microscópico (Figura 22F). Talvez, o processo de seleção genética que gerou uma resposta inflamatória aguda mais intensa na linhagem AIRmax do que na linhagem AIRmin, possa também de alguma forma, contribuir para o intenso processo inflamatório crônico caracterizado pela forte infiltração celular nessa linhagem, pelo menos até período de 30 dias. É provável que outros mediadores não estudados aqui, estejam agindo sinergicamente para a manutenção desse processo e por isso uma pesquisa mais detalhada nesse sentido, deve ser necessária.

A expressão de Tgfb que é uma citocina anti-inflamatória, também está aumentada nos AIRmax aos 30 dias (Figura 19). Na resposta inflamatória tardia, o reconhecimento de células apoptóticas por macrófagos, estimula o término da produção de citocinas pró-inflamatórias por essas células e estimula a produção de citocinas anti-inflamatórias como o TGF- $\beta$ e a IL-10 (LAWRENCE; GILROY, 2007). Por tanto a expressão de Tgfb na pele e a detecção de IL-10 no soro, podem ser um indicativo que apesar de os animais AIRmax regularem positivamente alguns mediadores inflamatórios, a produção de mediadores anti-inflamatórios também é aumentada nesse período, provavelmente para tentar conter a inflamação e estimular o processo de resolução. Por outro lado, a persistência do agente inflamatório no local da lesão, nesse caso o Biogel, e alta capacidade dessas linhagens de responder a um estímulo inflamatório, levam à produção e ao 
recrutamento contínuo e intenso de células imunes ao local inflamado, principalmente de macrófagos, que é a principal célula envolvida no desenvolvimento de respostas crônicas e na formação de granulomas. A presença de diferentes populações de macrófagos nos granulomas, como os macrófagos classicamente ativados (CAMs) e macrófagos alternativamente ativados (AAMs) pode ser crucial para o sucesso de um granuloma. Os CAMs são basicamente células produtoras de citocinas inflamatórias como o TNF-a e IL-12 e os AAMs são macrófagos que produzem citocinas anti-inflamatórias como o TGF- $\beta$ e a IL-10. Enquanto os CAMs são requeridos para eliminar o estímulo inflamatório, eles também podem levar ao dano tecidual. Por outro lado, os AAMs podem prejudicar a eliminação do agente inflamatório, enquanto diminuem a resposta pró-inflamatória e, portanto o dano tecidual. Assim, o balanço entre esses dois tipos celulares pode ser necessário para controlar um estímulo inflamatório e ao mesmo tempo evitar o dano tecidual (FLYNN; CHAN; LIN, 2011).

De acordo com trabalhos anteriores do nosso grupo, que mostraram que os camundongos AIRmin desenvolvem mais carcinoma de pele (BIOZZI et al., 1998) e de pulmão (MARIA et al, 2003; RIBEIRO et al., 2005) do que camundongos AIRmax, devido a uma inflamação persistente, e que os AIRmax resolvem essa inflamação mais rapidamente, nós acreditamos que da mesma forma que os animais selecionados para a máxima AIR são capazes de inflamar com grande intensidade, eles tem uma capacidade maior de resolver essa inflamação. No entanto, no nosso modelo de inflamação contínua com Biogel por 30 dias o processo inflamatório foi persistente e mais intenso em camundongos AIRmax do que em camundongos AIRmin apesar de os animais AIRmin mostrarem um aumento no número de células no exsudato e os animais AIRmax mostrarem uma diminuição desse infiltrado.

As linhagens AIRmax e AIRmin constituem uma ferramenta importante para o mapeamento de genes modificadores da inflamação e os nossos dados permitem entender melhor os mecanismos envolvidos nas respostas infamatória aguda e crônica às partículas de Biogel. O nosso estudo mostrou que alguns genes envolvidos com a resposta inflamatória aguda, além de se mostrarem diferentemente expressos entre as linhagens após o período de 48 horas também apresentaram diferença após 30 dias. Além disso, diferenças no infiltrado celular local e nas características do tecido subcutâneo também foram observadas, indicando que o 
processo de seleção para a resposta inflamatória aguda, pode ter afetado também a resposta inflamatória crônica ao agente selecionador e revelando, portanto, indícios de que pode haver um controle genético comum para ambas as respostas. Assim, o presente trabalho contribui para a identificação de fatores genéticos que controlam tanto a intensidade da resposta inflamatória aguda como a intensidade resposta inflamatória crônica. 


\section{CONCLUSÕES}

$>0$ estímulo com Biogel induziu uma forte resposta inflamatória local nos animais AIRmax, caracterizado por uma maior infiltração celular não só em 48 horas mas também aos 30 dias, com maior detecção de citocinas no exsudato e maior ativação de transcritos de genes no tecido dessa linhagem do que na linhagem AIRmin após 48 horas.

$>$ Em ambas as linhagens, após o estímulo com Biogel por 48 horas, nos ensaios de microarray, os genes ativados estiveram agrupados principalmente nas categorias de transdução de sinal, resposta imune e resposta inflamatória.

$>$ Nos animais AIRmax experimentais, um grupo de genes principalmente envolvidos com transdução de sinal, resposta inflamatória, resposta imune e adesão celular foram pelo menos 2 vezes mais expressos que na linhagem AIRmin.

Entre as categorias de genes sobre-representados e mais expressos nos animais AIRmin após a injeção de Biogel, estão alguns genes envolvidos com resposta imune, regulação da contração muscular e organização do citoesqueleto. Essas duas últimas categorias biológicas apareceram mais expressas nos camundongos AIRmin provavelmente devido à repressão observada na linhagem AIRmax.

A presença do Biogel no subcutâneo dos animais AIRmax foi capaz de induzir a formação de um possível granuloma, observado ao exame macroscópico após 30 dias.

$>$ A expressão de Tnfa, Cc/2, Itgb2 e Vcam1 está aumentada na linhagem AlRmax após 30 dias do tratamento, que também mostrou intenso infiltrado inflamatório de neutrófilos, macrófagos e células gigantes multinucleadas, à análise do tecido. 
$>$ A expressão da citocina anti-inflamatória Tgfb apareceu aumentada na linhagem AIRmax somente após 30 dias da aplicação de Biogel, mesmo período em que outra citocina anti-inflamatória, a IL-10 foi detectada em concentrações elevadas no soro da mesma. 


\section{REFERÊNCIAS ${ }^{1}$}

ARAÚJO, L. M.; RIBEIRO, O. G.; SIQUEIRA, M.; DE FRANCO, M.; SATAROBINAS, N.; MASSA, S.; CABRERA, W. H.; MOUTON, D.; SEMAN, M.; IBAÑEZ, O. M. Innate resistance to infection by intracellular bacterial pathogens differs in mice selected for maximal or minimal acute inflammatory response. Eur. J. Immunol., v. 28, p. 2913-2920, 1998.

ARMSTRONG, D. A.; MAJOR, J. A.; CHUDYK, A.; HAMILTON, T. A. Neutrophil chemoattractant genes KC and MIP-2 are expressed in different cell populations at sites of surgical injury. J. Leukoc. Biol., v. 75, p. 641-648, 2004.

AWOMOYI, A. A. The human solute carrier family11member1protein (SLC11A1): linking infections, autoimmunityand cancer? FEMS Immunol. Med. Microbiol., v. 49, p. 324-329, 2007.

BALKWILL, F. Tumour necrosis factor and cancer. Nat. Rev. Cancer, v. 9, p. 361-371, 2009.

BIOZZI, G.; RIBEIRO, O. G.; SARAN, A.; ARAÚJO, M. L.; MARIA, D. A.; DE FRANCO, M.; CABRERA, W. H.; SANT'ANNA, O. A.; MASSA, S.; COVELLI, V.; MOUTON, D.; NEVEU, T.; SIQUEIRA, M.; IBAÑEZ, O. M. Effect of genetic modification of acute inflammatory responsiveness on tumorigenesis in the mouse. Carcinogenesis, v. 18, p. 337-346, 1998.

BORREGO, A.; PETERS, L. C.; JENSEN, J. R.; RIBEIRO, O. G.; A, CABRERA, W. H. K.; STAROBINAS, N.; SEMAN, M.; IBAÑEZ, O. M.; DE FRANCO, M. Genetic determinants of acute inflammation regulate Salmonella infection and modulate Slc11a1 gene (formerly Nramp1) effects in selected mouse lines. Microbes Infect., v. 8, p. 2766-2771, 2006.

CARABEO, R. A.; GRIESHABER, S. S.; ISCHER, E.; HACKSTADT, T. Chlamydia trachomatis Induces Remodeling of the Actin Cytoskeleton during Attachment and Entry into HeLa Cells. Infect. Immun., v. 70, n. 7, p. 3793-3803, 2002.

CARNEIRO, A. S.; RIBEIRO, O. G.; DE FRANCO, M.; CABRERA, W. H.; VORRARO, F.; SIQUEIRA, M.; IBAÑEZ, O. M.; STAROBINAS, N. Local inflammatory reaction induced by bothrops jararaca venom differs in mice selected for acute inflammatory reaction. Toxicon, v. 40, p. 1571-1579, 2002.

CARNEIRO, P. S.; PETERS, L. C.; VORRARO, F.; BORREGO, A.; RIBEIRO, O. G.; STAROBINAS, N.; JENSEN, J. R.; CABRERA, W. H. K.; IBAÑEZ, O. M.; DE FRANCO, M. Gene expression profiles of bone marrow cells from mice phenotype-selected for maximal or minimal acute inflammations: searching for

\footnotetext{
${ }^{1}$ De acordo com:

ASSOCIAÇÃO BRASILEIRA DE NORMAS TÉCNICAS. NBR 6023: informação e documentação: referências: elaboração. Rio de Janeiro, 2002.
} 
genes in acute inflammation modifier loci. Immunology, v. 128, p. 562-571, 2009.

CHAPLIN, D. D. Overview of the Immune Response. J. Allergy Clin. Immunol., v. 125, n.2, p. S3-23, 2010. Suppl. 2.

CHEN, G. Y; NUÑEZ, G. Sterile inflammation: sensing and reacting to damage. Nat. Rev. Immunol., v. 10, p. 827-837, 2010.

COUSSENS, L. M.; WERB, Z. Inflammation and cancer. Nature, v. 420, p. 860867,2002

DE FRANCO, M.; CARNEIRO, P. S.; PETERS, L. C.; VORRARO, F.; BORREGO,, A.; RIBEIRO O. G.; STAROBINAS, N.; CABRERA, W. H.; IBAÑEZ, O. M. Slc 11a1 (Nramp1) alleles interact with acute inflammation loci to modulate wound-healing traits in mice. Mamm. Genome, v. 18, p. 263-269, 2007.

DESHMANE, S. L.; KREMLEV, S.; AMINI, S.; SAWAYA, B. E. Monocyte chemoattractant protein 1 (MCP-1): an overview. J. Interferon Cytokine Res., v. 29, n. 6, p. 313-326, 2009.

DINARELLO, C. A. Immunological and inflammatory functions of the interleukin-1 family. Annu. Rev. Immunol., v. 27, p. 519-50, 2009.

DI PACE, R. F.; MASSA, S.; RIBEIRO, O. G.; CABRERA, W. H. K.; DE FRANCO, M.; STAROBINAS, N.; SEMAN M.; IBAÑEZ, O. C. M. Inverse genetic predisposition to colon versus lung carcinogenesis in mouse lines selected based on acute inflammatory responsiveness. Carcinogenesis, v. 27, n. 8, p. 15171525, 2006.

ERNST, P. B. The disease spectrum of helicobacter pylori: The immunopathogenesis of Gastroduodenal Ulcer and Gastric Cancer. Annu. Rev. Microbiol., v. 54, p. 615-40, 2000.

FADOK, V. A.; BRATTON, D. L.; KONOWAL, A.; FREED, P. W.; WESTCOTT, J. Y.; HENSON, P. M. Macrophages that have ingested apoptotic cells in vitro inhibit proinflammatory cytokine production through autocrine/paracrine mechanisms involving TGFb, PGE2, and PAF. J. Clin. Invest., v. 101, p. 890-898, 1998.

FERNANDES, J. G. Análise comparativa dos processos inflamatórios agudo e crônico no tecido subcutâneo e exsudato de camundongos selecionados para máxima ou mínima inflamação. 2012. 87 f. Dissertação (Mestrado em Ciências). Instituto de Ciências Biomédicas, Universidade de São Paulo, São Paulo, 2012.

FLYNN, J. L.; CHAN, J.; LIN, P. L. Macrophages and control of granulomatous inflammation in tuberculosis. Mucosal Immunol., v. 4, n. 3, p. 271-278, 2011. 
FORSSMANN, U.; UGUCCIONI, M.; LOETSCHER, P.; DAHINDEN, C. A.; LANGEN, H.; THELEN, M.; BAGGIOLINI, M. Eotaxin-2, a novel CC chemokine that is selective for the chemokine receptor CCR3, and acts like eotaxin on human eosinophil and basophil leukocytes. J. Exp. Med., v. 185, n. 12, p. 21712176, 1997.

FRÉNAL, K.; SOLDATI-FAVRE, D. Role of the Parasite and Host Cytoskeleton in Apicomplexa Parasitism. Cell Host Microbe, v. 5, p. 602-611, 2009.

GABAY, C. Interleukin-6 and chronic inflammation. Arthritis Res. Ther., v. 8, p. 1-6, 2006.

GALVAN, A.; VORRARO, F.; CABRERA, W.; RIBEIRO, O. G.; STAROBINAS, N.; JENSEN, J, R.; CARNEIRO, P. S.; DE FRANCO, M.; GAO X.; IBAÑEZ, O. C. M.; DRAGANI, T. A. Association study by genetic clustering detects multiple inflammatory response loci in non-inbred mice. Genes Immun., v. 12, p. 390-394, 2011.

GIULIETTI, A.; OVERBERGH, L.; VALCKX, D.; DECALLONNE, B.; BOUILLON, R.; MATHIEU, C. An overview of real-time quantitative PCR: applications to quantify cytokine gene expression. Methods, v. 25, p. 386-40, 2001.

GONLUGUR, U.; GONLUGUR, T. E. Non-allergic eosinophilic inflammation. Immunol. Invest., v. 35, p. 29-45, 2006.

HASEL, K. W.; SUTCLIFFE, J. G. Nucleotide sequence of a cDNA coding for mouse Cyclophilin. Nucleic Acids Res., v. 18,n. 13, p. 4019, 1990.

HIGGINS, D. M.; BASARABA, R. J.; HOHNBAUM, A. C.; LEE, E. J.; GRAINGER, D. W.; GONZALEZ-JUARRERO, M. Localized immunosuppressive environment in the foreign body response to implanted biomaterials. Am. J. Pathol., v. 175, n. 1, p. 160-170, 2009.

HINSBERGH, V. W. M. V.; KOOLWIJK, P. Endothelial sprouting and angiogenesis: matrix metalloproteinases in the lead. Cardiovasc Res., v. 78, p. 203-212, 2008.

HOSACK, D. A.; DENNIS, G. JR.; SHERMAN, B. T.; LANE, H. C; LEMPICKI, R. A. Identifying biological themes within lists of genes with EASE. Genome Biol., v. 4, p. R70, 2003.

HUNTER, K. W.; CRAWFORD, N. P. S. The future of mouse QTL mapping to diagnose in mice in the age of role genome association studies. Annu. Rev. Genet., v. 42, p. 131-41, 2008.

HURST, S.M.; WILKINSON, T. S.; MCLOUGHLIN, R. M.; JONES, S.; HORIUCHI, S.; YAMAMOTO, N.; ROSE-JOHN, S.; FULLER, G. M.; TOPLEY, N.; JONES, S. A. IL-6 and its soluble receptor orchestrate a temporal switch in the pattern of leukocyte recruitment seen during acute inflammation. Immunity, v. 14, p. 705714, 2001. 
HUYNH, M. L.; FADOK, V. A.; HENSON, P. M. Phosphatidylserine-dependent ingestion of apoptotic cells promotes TGFbeta1 secretion and the resolution of inflammation. J. Clin. Invest., v. 109, p. 41-50, 2002.

IBANHEZ, O. M.; STIFFEL, C.; RIBEIRO, O. G.; CABRERA, W. H.; MASSA, S.; DE FRANCO, M.; SANTAANA, O. A.; DECREUSENFOND, C.; MOUTON, D.; SIQUEIRA, M.; BIOZZI, G. Genetics of nonspecific immunity: I. Bidirectional selective breeding of lines of mice endowed with maximal or minimal inflammatory responsiveness. Eur. J. Immunol., v. 22, p. 2555-2563, 1992.

JIANG, D.; LIANG, J.; FAN, J.; YU, S.; CHEN, S.; LUO, Y.; PRESTWICH, G. D.; MASCARENHAS, M. M.; GARG, H. G.; QUINN, D. A; HOMER, R. J.; GOLDSTEIN, D. R.; BUCALA, R.; LEE, P. J.; MEDZITOV, R.; NOBLE, P. W. Regulation of lung injury and repair by toll-like receptors and hyaluronan. Nature, v. 11, n. 11, p. 1173-1179, 2005.

KAPLANSKI, G.; MARIN, V.; JULIAN, F. M.; MANTOVANI, A.; FARNARIER C.; IL-6: A regulator of the transition from neutrophil to monocyte recruitment during inflammation. Trends Immunol., v. 24, p. 25-29, 2003.

KORN, T.; BETTELLI, E.; OUKKA, M.; KUCHROO, V. K. IL-17 and Th17 Cells. Annu. Rev. Immunol., v. 27, p. 485-517, 2009.

KULKARNI, A. B.; HUH, C. G.; BECKER, D.; GEISER, A.; LYGHT, M.; FLANDERS, K. C.; ROBERTS, A. B.; SPORN, M. B.; WARD, J. M.; KARLSSON, $S$. Transforming growth factor 181 null mutation in mice causes excessive inflammatory response and early death. Proc. Natl, Acad. Sci., v. 90, p. 770774, 1993.

LANGER, H. F.; CHAVAKIS, T. Leukocyte-endothelial interactions in inflammation. J. Cell. Mol. Med., v. 13, n. 7, p. 1211-1220, 2009.

LAWRENCE, T.; GILROY, D. W. Chronic inflammation: a failure of resolution? Int. J. Exp. Pathol., v. 88, p. 85-94, 2007.

LEEMANS, J.C.; CASSEL, S. L.; SUTTERWALA, F. S. Sensing damage by the NLRP3 Inflammasome. Immunol Rev., v. 243, p. 152-162, 2011.

LEY, K.; LAUDANNA, C.; CYBULSKY, M. I.; NOURSHARGH, S. Getting to the site of inflammation: the leukocyte adhesion cascade updated. Nat. Immunol., v. 7, p. 678-689, 2007.

LI, A. G.; LU, S. L.; HAN, G.; HOOT, K. E.; WANG, X. J. Role of TGF- $\beta$ in Skin Inflammation and Carcinogenesis. Mol. Carcinog., v. 45, p. 389-396, 2006.

LINT, P. V.; LIBERT, C. Matrix metalloproteinase-8: clevage can be decisive. Cytokine Growth Factor Rev., v. 17, p. 217-223, 2006. 
LIVAK, K. J.; SCHMITTGEN, T. D. Analysis of relative gene expression data using real-time quantitative $\mathrm{PCR}$ and the $2^{-\Delta \Delta C}$ T method. Methods, v. 25, p. 402408, 2001.

LUSTER, A. D.; ALON, R.; ANDRIAN, U. H. V. Immune cell migration in inflammation: present and future therapeutic targets. Nat. Immunol., v. 6, p. 1182-1190, 2005.

MALEFYT, R. DE W.; ABRAMS, J.; BENNETT, B.; FIGDOR, C. G.; DE VRIES, J. E. Interleukin 10(IL-10) inhibits cytokine synthesis by human monocytes: an autoregulatory role of IL-10 produced by monocytes. J. Exp. Med., v. 174, p. 1209-20, 1991.

MARIA, D. A; MANENTI, G.; GALBIATI, F.; RIBEIRO, O. G.; CABRERA, W. H. K.; BARRERA, R. G.; PETTINICCHIO,, A.; DE FRANCO M.; STAROBINAS, N.; SIQUEIRA, M.; DRAGANI, T.A.;IBAÑEZ, O. M. Pulmonary adenoma susceptibility 1 (Pas1) locus affects inflammatory response. Oncogene, v. 22, p. 426-432, 2003.

MARTINON, F.; MAYOR, A.; TSCHOPP, J. The inflammasomes: guardians of the body. Annu. Rev. Immunol., v. 27, p. 229-265, 2009.

MATZER, S. P.; BAUMANN, T.; LUKACS, N. W.; RÖLLINGHOFF, M.; BEUSCHER, H. U. Constitutive expression of macrophage-inflammatory Protein 2 (MIP-2) mRNA in bone marrow gives rise to peripheral neutrophils with preformed MIP-2 protein. J. Immunol., v. 167, p. 4635-4643, 2001.

MCDONALD, B.; KUBES, P. Cellular and molecular choreography of neutrophil recruitment to sites of sterile inflammation. J. Mol. Med., v. 89, p. 1079-1088, 2011.

MEDZHITOV, R. Origin and physiological roles of inflammation. Nature, v. 454, n. 24, p. 428-435, 2008.

MEDZHITOV, R. Inflammation 2010: New Adventures of an Old Flame. Cell, v. 140, p. 771-776, 2010.

MEDZHITOV, R.; JANEWAY, C. Innate Immunity. N. Engl. J. Med., v. 343, p. 338-344, 2000.

MOGENSEN, T. H. Pathogen Recognition and Inflammatory Signaling in Innate Immune Defenses. Clin. Microbiol. Rev., v. 22, n. 2, p. 240-273, 2009.

MÖLLER, B.; VILLIGER, P. M. Inhibition of IL-1, IL-6, and TNF- $\alpha$ in immunemediated inflammatory diseases. Springer Semin. Immun., v. 27, p. 391-408, 2006.

MORAIS, J. M.; PAPADIMITRAKOPOULOS, F; BURGESS, D. J. Biomaterials/tissue interactions: possible solutions to overcome foreign body response. AAPS J., v. 12, n. 2, p. 188-196, 2010. 
MOUSE GENOMIC INFORMATICS. Genes, genome, features \& maps. 2012. Disponível em <http://www.informatics.jax.org/marker/MGl:105303>. Acesso em: 02 Feb 2012.

MURPHY, G.; NAGASE, H. Progress in matrix metalloproteinase research. Mol. Aspects Med., v. 29, p. 290-308, 2008.

NATHAN, C. Points of control in inflammation. Nature, v. 420, p. 19-26, 2002.

NOWAK, D.; POPOW-WOŹNIAK, A.; RAŹNIKIEWICZ, L.; MALICKABLASZKIEWICZ, M. Actin in the wound healing process. Postepy Biochem., v. 55, n. 22, p. 138-44, 2009.

PARAMESWARAN, N.; PATIAL, S. Tumor necrosis factor- $\alpha$ signaling in macrophages. Crit. Rev. Eukaryot. Gene Expr., v. 20, n. 2, p. 87-103, 2010.

PARKS, W.C.; WILSON, C. L.; LOPEZ-BOADO, Y. S. Matrix metalloproteinases as modulators of inflammation and innate immunituy. Nat. Immunol., v. 4, p. 617629, 2004.

PERRETI, M. Endogenous mediators that inhibit the leukocyte-endothelium interaction. Trends Pharmacol Sci., v. 18, p. 418-425, 1997.

PETERS, L.C.; JENSEN, J. R.; ,BORREGO, A.; CABRERA, W.H. K.; BAKER, N.; STAROBINAS, N.; RIBEIRO, O. G.; IBAÑEZ, O. M.;DE FRANCO, M. SIc11a1 (formerly NRAMP1) gene modulates both acute inflammatory reactions and pristane-induced arthritis in mice. Genes Immun., v. 8, p. 51-56, 2007.

PRINCE, L. R.; WHYTE, M. K. ; SABROE, I.; PARKER, L. C. The role of TLRs in neutrophil activation. Cur. Opin. Pharmacol., v. 11, p. 397-403, 2011.

RIBEIRO, O. G. F. Controle genético da inflamação. 1994. 85 f. Dissertação (Mestrado em Microbiologia e Imunologia) - Escola Paulista de Medicina, São Paulo, 1994.

RIBEIRO, O. G.; MARIA, D. A.; ADRIOUCH, S.; PECHBERTY, S.; CABRERA, W. H. K.; MORRISET, J.; IBAÑEZ O. M.; SEMAN, M. Convergent alteration of granulopoiesis, chemotactic activity, and neutrophil apoptosis during mouse selection for high acute inflammatory response. J. Leukoc. Biol., v. 74, p. 497506, 2003.

RIBEIRO, O. G.; CABRERA, W. H. K.; MARIA, D. A.; DE FRANCO, M.; MASSA, S.; DI PACE, R. F.; SOUZA, V. R. C.; STAROBINAS, N.; SEMEN, M.; IBAÑEZ, $O$. M. Genetic selection for high acute inflammatory response confers resistance to lung carcinogenesis in the mouse. Exp. Lung Res., v. 31, p. 105-116, 2005.

ROCHE, J. K.; KEEPERS, T. R.; GROSS, L. K.; SEANER, R. M.; OBRIG, T. G. CXCL1/KC and CXCL2/MIP-2 Are Critical Effectors and Potential Targets for 
Therapy of Escherichia coli O157:H7-Associated Renal Inflammation. Am. J. of Pathol., v. 170, n. 2, p. 526-537, 2007.

ROCK, K. L.; LATZ E.; ONTIVEROS, F.; KONO, H. The Sterile Inflammatory Response. Annu. Rev. Immunol., v. 28, p. 321-42, 2010.

RODRIGUES, G. C.; LACERDA, D. C.; GUSMÃO, E. DA S.; COLARES, F. A.; MOTA, V. T. Pseudotumoral presentation of chronic pulmonary schistosomiasis without pulmonary hypertension. J. Bras. Pneumol., v. 35, n. 5, p. 484-488, 2009.

ROTHENBERG, M. E.; HOGAN, S. P. The Eosinophil. Annu. Rev. Immunol., v. 24 , p. $147-74,2006$.

RYAN, G. B.; MAJNO, G. Acute inflammation. A review. Am. J. Pathol., v. 86, n. 1, p. 183-276, 1977.

SABAT, R.; GRU, G.; WARSZAWSKA, K.; KIRSCH, S.; WITTE, E.; WOLK, K.; GEGINAT, J. Biology of interleukin-10. Cytokine Growth Factor Rev., v. 21, p. 331-344, 2010.

SERHAN, C. N. A search for endogenous mechanisms of anti-inflammation uncovers novel chemical mediators: missing links to resolution. Histochem. Cell Biol., v. 122, p. 305-321, 2004.

SERHAN, C. N.; SAVILL, J. Resolution of inflammation: the beginning programs the end. Nat. Immunol., v. 6, p. 1191-1197, 2005.

SERHAN, C. N.; BRAIN, S. D.; BUCKLEY, C. D.; GILROY, D. W.; HASLETT, C.; O'NEILL, L. A. J.;PERRETTI, M.; ROSSI, A. G.; WALLACE, J. L. Resolution of inflammation: state of the art, definitions and terms. Faseb J., v. 21, p. 325-332, 2007.

SOROKIN, L. The impact of the extracellular matrix on inflammation. Nat. Immunol., 2010. 10: 217 - 223.

STIFFEL, C.; IBAÑEZ, O.M.; RIBEIRO, O.G.; DECRESEFOND, C.; MOUTON, D.; SIQUEIRA, M.; BIOZZI, G. Genetics of acute inflammation: inflammatory reactions in inbred lines of mice and their interline crosses. Expl. Clin. Immunogenet., v. 7, p. 221-233, 1990.

SUMAGIN, R.; LOMAKINA, E.; SARELIUS, I. H. Leukocyte-endothelial cell interactions are linked to vascular permeability via ICAM-1-mediated signaling. Am. J. Physiol. Heart Circ. Physiol., v. 295, p. H969-H977, 2008.

SWEENEY, S. E.; FIRESTEIN, G. S. Rheumatoid arthritis: regulation of synovial inflammation. Int. Journal of Biochem. Cell Biol., v. 36, p. 372-378, 2004.

SZKARADKIEWICZ, A.; MARCINIAK, R.; STRUGALA, I. C.; WASILEWSKA, A.; DREWS, M.; MAJEWSKI, P.; KARPIŃSKI, T.; ZWOŹDZIAK, B. Proinflammatory 
cytokines and IL-10 in inflammatory bowel disease and colorectal cancer patients. Arch. Immunol. Ther. Exp., v. 57, p. 291-294, 2009.

TRACEY, D.; KLARESKOG, L.; SASSO, E. H.; SALFELD, J. G..; TAK, P. P. Tumor necrosis factor antagonist mechanisms of action: A comprehensive review. Pharmacol Ther., v. 117, p. 244-279, 2008.

VASQUEZ-BRAVO, Y. L. A. R. Aspecto da resposta inflamatória agida em linhagens de camundongos com reatividade máxima (AIRmax) e mínima (AIRmin) obtidas por seleção genética bidirecional. 1996. 50 f. Tese (Doutorado em Imunologia) - Instituto de Biociências, Universidade de São Paulo, São Paulo, 1996.

VIDAL, S.; TREMBLAY, M. L.; GOVONI, G.; GAUTHIER, S.; SEBASTIANI, G.; MALO, D.; SKAMENE, E.; OLIVIER, M.; JOTHY, S.; GROS, P. The Ity/Lsh/Bcg Locus: Natural Resistance to Infection with Intracellular Parasites Is Abrogated by Disruption of the Nramp1 Gene. J. Exp. Med., v. 182, p. 655-666, 1995.

VIGAR, N. D.; CABRERA, W. H.; ARAÚJO, L. M.; RIBEIRO, O. G.; OGATA, T. R.; SIQUEIRA, M.; IBAÑEZ, O. M.; DE FRANCO, M. Pristane-induced arthritis in mice selected for maximal or minimal acute inflammatory reaction. Eur $\mathbf{J}$. Immunol., v. 30, p. 431-437, 2000.

VISSER, K. E. De.; EICHTEN, A.; COUSSENS, L. M. Paradoxical roles of the immune system during cancer development. Nat. Rev. Cancer, v. 6, p. 24-37, 2006.

VORRARO, F.; GALVAN, A. ; CABRERA, W. H. K.; CARNEIRO, P. S.; RIBEIRO, O. G.; DE FRANCO, M.; STAROBINAS, N.; JENSEN, J. R.; SEMAN, M.; DRAGANI, T. A.; IBAÑEZ, O. C. M. Genetic Control of IL-1b Production and Inflammatory Response by the Mouse Irm1 Locus. J. Immunol., v. 185, p. 16161621, 2010.

WAHL, S.M. Transforming Growth Factor/3: The Good, the Bad, and the Ugly. J. Exp. Med., v. 180, p. 1587-1590, 1994.

WALLIS, R. S. Tumour necrosis factor antagonists: structure, function, and tuberculosis risks. Lancet Infect. Dis., v. 8, p. 601-611, 2008.

WALLIS, R. S.; EHLERS, S. Tumor Necrosis Factor and Granuloma Biology: Explaining the Differential Infection Risk of Etanercept and Infliximab. Semin. Arthritis Rheum., v. 34, p. 34-38, 2005.

WEBER, A.; WASILIEW, P.; KRACHT, M. Interleukin-1 (IL-1) Pathway. Sci Signal., v. 3, n. 105, p. 1-6, 2010.

ZHANG, X.; ANGKASEKWINAI, P.; DONG, C.; TANG, H. Structure and function of interleukin-17 family cytokines. Protein Cell, v. 2, n. 1, p. 26-40, 2011. 